Nevada

Environmental

Restoration

Project

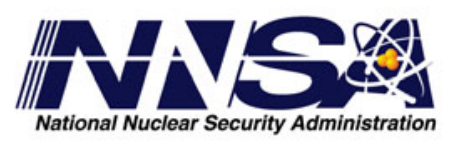

\title{
Screening Risk Assessment for Possible Radionuclides in the Amchitka Marine Environment
}

Revision No.: 0

October 2002

\section{Environmental Restoration}

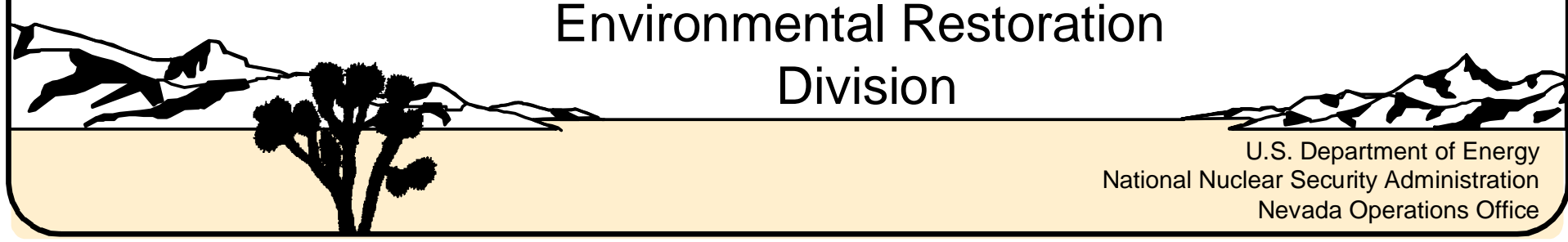


Available for public sale, in paper, from:

U.S. Department of Commerce

National Technical Information Service

5285 Port Royal Road

Springfield, VA 22161

Phone: 800.553 .6847

Fax: 703.605.6900

Email: orders@ntis.fedworld.gov

Online ordering: http://www.ntis.gov/ordering.htm

Available electronically at http://www.doe.gov/bridge

Available for a processing fee to U.S. Department of Energy and its contractors, in paper, from:

U.S. Department of Energy

Office of Scientific and Technical Information

P.O. Box 62

Oak Ridge, TN 37831-0062

Phone: 865.576 .8401

Fax: 865.576.5728

Email: reports@adonis.osti.gov

Reference herein to any specific commercial product, process, or service by trade name, trademark, manufacturer, or otherwise, does not necessarily constitute or imply its endorsement, recommendation, or favoring by the United States Government or any agency thereof or its contractors or subcontractors. 


\title{
SCREENING RISK ASSESSMENT FOR POSSIBLE RADIONUCLIDES IN THE AMCHITKA MARINE ENVIRONMENT
}

\author{
Prepared for \\ U.S. Department of Energy \\ National Nuclear Security Administration \\ Nevada Operations Office \\ Las Vegas, Nevada
}

Revision No.: 0

October 2002

Approved for public release; further dissemination unlimited. 


\section{SCREENING RISK ASSESSMENT FOR POSSIBLE RADIONUCLIDES IN THE AMCHITKA MARINE ENVIRONMENT}

Approved by: Signature Approved

Date: $10 / 31 / 02$

Monica Sanchez, Project Manager

Offsites Project

Date: $10 / 31 / 02$ 


\section{Table of Contents}

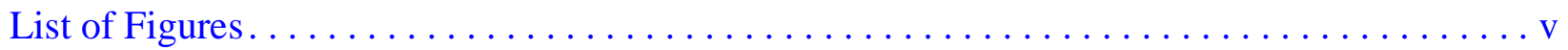

List of Tables. . . . . . . . . . . . . . . . . . . . . . . . . . . . . .

List of Acronyms and Abbreviations $\ldots \ldots \ldots \ldots \ldots \ldots \ldots \ldots \ldots \ldots \ldots \ldots \ldots \ldots \ldots$ viii

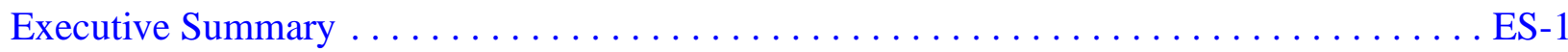

$1.0 \quad$ Introduction $\ldots \ldots \ldots \ldots \ldots \ldots \ldots \ldots \ldots \ldots \ldots \ldots \ldots \ldots \ldots \ldots \ldots \ldots \ldots \ldots, 1$

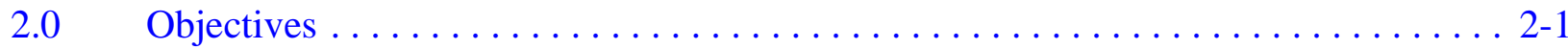

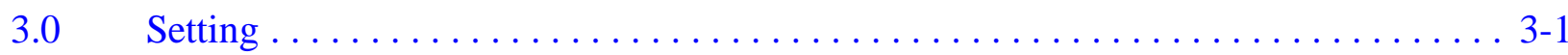

$4.0 \quad$ Conceptual Model . . . . . . . . . . . . . . . . . . . . . . . . . . 4 1

$5.0 \quad$ Steps of the Screening Risk Assessment. . . . . . . . . . . . . . . . . . . 5-1

$5.1 \quad$ Four Main Steps of Screening Risk Assessment .............. 5-1

5.2 Five Substeps of Screening Risk Assessment (Step B) . . . . . . . . . . 5-1

5.3 Eleven Elements. . . . . . . . . . . . . . . . . . . . . . . . . . . 5-2

$5.4 \quad$ Anticipated Exposure Volumes . . . . . . . . . . . . . . . . . . . . . . . 5-3

5.4.1 Small Volumes. . . . . . . . . . . . . . . . . . . . . . . . . 5-3

5.4.2 Large Volume .......................... 5-3

$5.5 \quad$ Calculational Process and Expected Output $\ldots \ldots \ldots \ldots \ldots \ldots \ldots \ldots$. . . . . . .

$5.6 \quad$ Risk Scenarios . . . . . . . . . . . . . . . . . . . . . . . . . . . . . 5-10

5.7 Application of Calculational Process. . . . . . . . . . . . . . . . 5-11

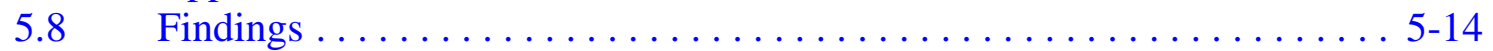

5.8.1 Scenario 1: Fish Subsistence Diet for Combined Source

of Cannikin, Long Shot, and Milrow (No Kelp) . . . . . . . . . 5-14

5.8.1.1 Base Case ....................... 5-14

5.8.1.2 Groundwater Modeling Sensitivity Case . . . . . . . 5-17

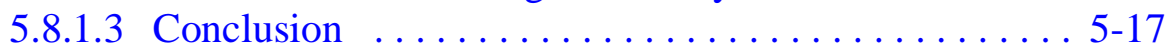

5.8.2 Scenario 2: Marine Mammal Subsistence Diet for

Combined Source of Cannikin, Long Shot,

and Milrow (No Kelp) . . . . . . . . . . . . . . . . 5-18

5.8.2.1 Base Case ...................... 5-18

5.8.2.2 Groundwater Modeling Sensitivity Case . . . . . . . 5-18

5.8.2.3 Conclusion ......................... . 5-19

5.8.3 Scenario 3: Commercial Catch Diet for Combined

Source of Cannikin, Long Shot, and Milrow (No Kelp) . . . . . . 5-19

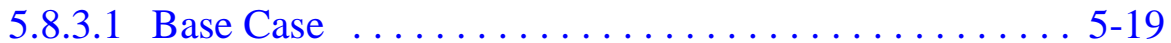

5.8.3.2 Groundwater Modeling Sensitivity Case . . . . . . . . 5-19

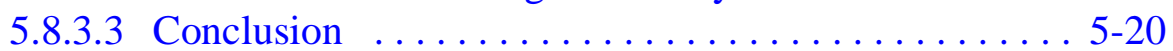

5.8.4 Scenario 4: Fish Subsistence Diet for Combined

Source of Cannikin, Long Shot, and Milrow (With Kelp) ... . 5 5-20

5.8.4.1 Base Case . . . . . . . . . . . . . . . . . . . . . . . . . . . 5-20 


\section{Table of Contents (Continued)}

5.8.4.2 Groundwater Modeling Sensitivity Case ... . . . . . 5-20

5.8.4.3 Conclusion .................... 5-21

5.8.5 Scenario 5: Marine Mammal Subsistence Diet for

Combined Source of Cannikin, Long Shot,

and Milrow (With Kelp) . . . . . . . . . . . . . . . . . 5-21

5.8.5.1 Base Case .................. . . . . 21

5.8.5.2 Groundwater Modeling Sensitivity Case ... . . . . 5-22

5.8.5.3 Conclusion .................... 5-22

5.8.6 Scenario 6: Commercial Catch Diet for Combined

Source of Cannikin, Long Shot, and Milrow (With Kelp) . . . . 5-22

5.8.6.1 Base Case ... . . . . . . . . . . . . . . . 5-22

5.8.6.2 Groundwater Modeling Sensitivity Case ....... . 5-23

5.8.6.3 Conclusion ................... 5-23

5.8.7 Scenario 7: Fish Subsistence Diet for Combined Sources

in the Aleut Culture and Communication Area . . . . . . . . 5-23

5.8.7.1 Base Case .................... 5-23

5.8.7.2 Groundwater Modeling Sensitivity Case ... . . . . . 5 5-24

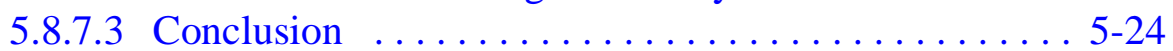

5.8.8 Scenario 8: Marine Mammal Subsistence Diet for

Combined Sources in the Aleut Culture and

Communication Area. . . . . . . . . . . . . . . . . 5-25

5.8.8.1 Base Case ................... 5-25

5.8.8.2 Groundwater Modeling Sensitivity Case ... . . . . 5-25

5.8.8.3 Conclusion .................... 5-26

5.8.9 Scenario 9: Commercial Catch Diet for Combined

Sources in the Aleut Culture and Communication Area . . . . . 5-26

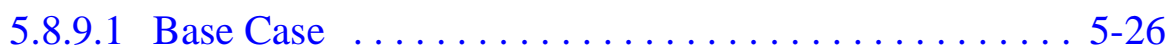

5.8.9.2 Groundwater Modeling Sensitivity Case ...... . 5-26

5.8.9.3 Conclusion ..................... 5-27

6.0 Data Quality and Uncertainty $\ldots \ldots \ldots \ldots \ldots \ldots \ldots \ldots \ldots \ldots \ldots \ldots \ldots \ldots$

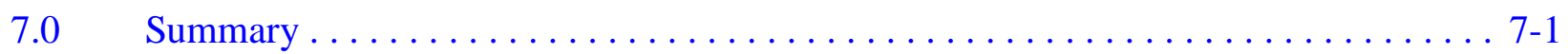

$8.0 \quad$ References . . . . . . . . . . . . . . . . . . . . . . . . . $8-1$

Appendix A - Exposition of Major Modeling Elements of Screening Risk Assessment for Possible Radionuclides in the Amchitka Marine Environment

A.1.0 Introduction . . . . . . . . . . . . . . . . . .

A.2.0 Radionuclides of Potential Concern $\ldots \ldots \ldots \ldots \ldots \ldots \ldots \ldots \ldots \ldots \ldots \ldots$. . . . . .

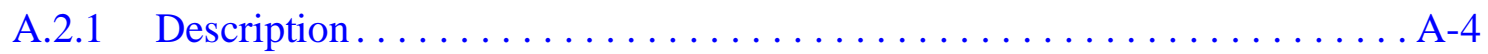

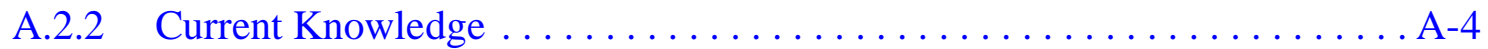

A.2.3 Discussion of Uncertainties . . . . . . . . . . . . . . . . . . . A-4

A.2.4 Implementation . . . . . . . . . . . . . . . . . . . . 


\section{Table of Contents (Continued)}

A.3.0 Locations of Releases $\ldots \ldots \ldots \ldots \ldots \ldots \ldots \ldots \ldots \ldots \ldots \ldots \ldots \ldots \ldots \ldots \ldots \ldots \ldots$

A.3.1 Description................................. A-7

A.3.2 Current Knowledge ........................... A-7

A.3.2.1 Groundwater Modeling . . . . . . . . . . . . . . . . A-7

A.3.2.2 Subsurface Orientation ....................... A-9

A.3.3 Discussion of Uncertainties . . . . . . . . . . . . . . . . . . . . . . A-9

A.3.4 Implementation . . . . . . . . . . . . . . . . .

A.4.0 Seabed Substrates $\ldots \ldots \ldots \ldots \ldots \ldots \ldots \ldots \ldots \ldots \ldots \ldots \ldots \ldots \ldots \ldots . \ldots \ldots$

A.4.1 Description................................ A-10

A.4.2 Current Knowledge ................................ . A-10

A.4.3 Discussion of Uncertainties . . . . . . . . . . . . . . . . . . . . . A-11

A.4.4 Implementation . . . . . . . . . . . . . . . . . . . . . . A -12

A.5.0 Transport by Currents . . . . . . . . . . . . . . . . . . . . . . . . . A-13

A.5.1 Description................................. A-13

A.5.2 Current Knowledge .............................. A-13

A.5.2.1 Oceanographic Setting....................... A-13

A.5.2.2 Current Pathways............................... A-14

A.5.2.3 Particle Dispersal .......................... A-15

A.5.3 Discussion of Uncertainties . . . . . . . . . . . . . . . . . . A-16

A.5.4 Implementation .............................. A-17

A.6.0 Dilution Including Plume $\ldots \ldots \ldots \ldots \ldots \ldots \ldots \ldots \ldots \ldots \ldots \ldots \ldots \ldots \ldots \ldots \ldots \ldots \ldots$

A.6.1 Description................................. A-18

A.6.2 Current Knowledge ............................ A-18

A.6.2.1 CORMIX Model Selection and Model Description . . . . . . . . A-19

A.6.2.2 Near-Shore Exposures in Plumes . . . . . . . . . . . . A-20

A.6.2.3 Offshore Exposure ....................... A-26

A.6.3 Discussion of Uncertainties . . . . . . . . . . . . . . . . . . . . A-27

A.6.4 Implementation . . . . . . . . . . . . . . . . . . . . . . . . . . A-29

A.7.0 Human Receptors . ............................ A-30

A.7.1 Description............................... A-30

A.7.2 Current Knowledge . . . . . . . . . . . . . . . . . . . . . . . . A-30

A.7.3 Discussion of Uncertainties . . . . . . . . . . . . . . . . . . . . . . . . A-30

A.7.4 Implementation . . . . . . . . . . . . . . . .

A.8.0 Distribution of Diet . . . . . . . . . . . . . . . . . . . . . . . A -33

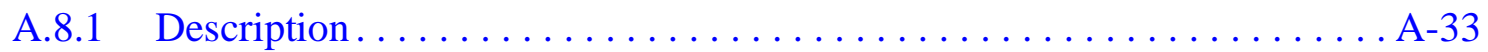

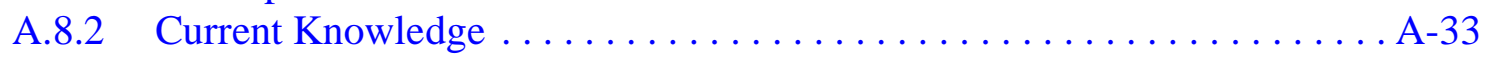

A.8.3 Discussion of Uncertainties . . . . . . . . . . . . . . . . . . A-34

A.8.4 Implementation ............................... A-35 


\section{Table of Contents (Continued)}

A.9.0 Bioconcentration Factors. $\ldots \ldots \ldots \ldots \ldots \ldots \ldots \ldots \ldots \ldots \ldots \ldots \ldots \ldots \ldots \ldots \ldots \ldots \ldots$

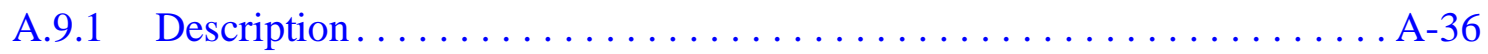

A.9.2 Current Knowledge ............................ A-36

A.9.3 Discussion of Uncertainties . . . . . . . . . . . . . . . . . A-37

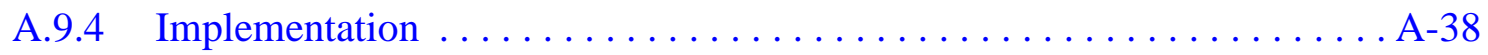

A.10.0 Fraction of Contaminated Diet . . . . . . . . . . . . . . . . . . . . . . . . A-40

A.10.1 Description ................................ A-40

A.10.2 Current Knowledge .............................. A-40

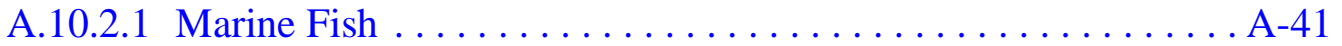

A.10.2.2 Marine Mammals......................... A-47

A.10.2.3 Derivation of Contaminated Fraction . . . . . . . . . . A-49

A.10.3 Discussion of Uncertainties . . . . . . . . . . . . . . . . . . A-50

A.10.4 Implementation . . . . . . . . . . . . . . . . . . . . .

A.11.0 Cancer Morbidity Risk Coefficients . . . . . . . . . . . . . . . . . A-53

A.11.1 Description ................................. A-53

A.11.2 Current Knowledge ............................. A-53

A.11.3 Discussion of Uncertainties . . . . . . . . . . . . . . . . . . A-53

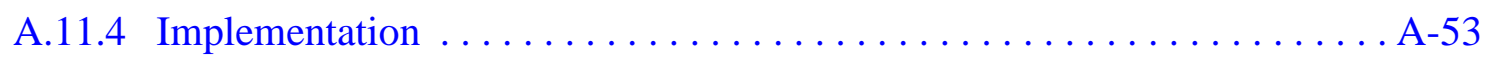

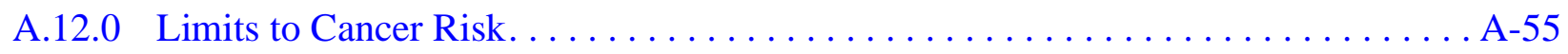

A.12.1 Description ................................. A-55

A.12.2 Current Knowledge .............................. A-55

A.12.3 Discussion of Uncertainties . . . . . . . . . . . . . . . . . . . A-55

A.12.4 Implementation ................................ A-56

A.13.0 Calculation of Risks . . . . . . . . . . . . . . . . . . . . . . . . . . A-57

A.13.1 Discussion of Uncertainties . . . . . . . . . . . . . . . . . . . A-57

A.14.0 Relationships of Site Closure Activities . . . . . . . . . . . . . . . . A-58

A.15.0 References . . . . . . . . . . . . . . . . . . . . . . . . . . . . . . . . A A-59 
Number

Title

1 Inset of Amchitka Island and Nearby Islands in Aleutian Islands

Relative to Larger Scale Geography..........................F-1

2 Conceptual Risk Assessment Model. ....................... F-2

3 Vertical Zonation or Exposure Depths for Kelp, Marine Mammals, and Marine Fishes Around Amchitka Island .....................F-3

$4 \quad$ Steps and Substeps in the Screening Risk Assessment

Relative to the Groundwater Model and Site Closure Plans ...............F-4

5 Scenario 1 - Fish Subsistence Diet for Combined Cannikin, Long Shot,

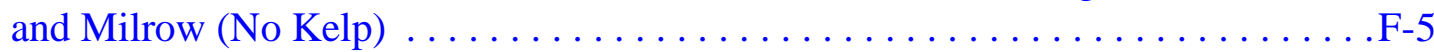

6 Scenario 2 - Mammal Subsistence Diet for Combined Cannikin, Long Shot,

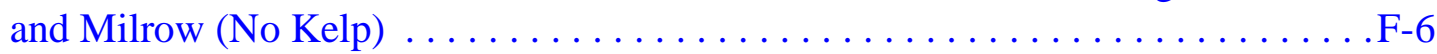

7 Scenario 3 - Commercial Catch Diet for Combined Cannikin, Long Row, and Milrow (No Kelp) ...............................

8 Scenario 4 - Fish Subsistence Diet for Combined Cannikin, Long Shot, and Milrow (With Kelp) ..............................

9 Scenario 5 - Mammal Subsistence Diet for Combined Cannikin, Long Shot, and Milrow (With Kelp) ................................

10 Scenario 6 - Commercial Catch Diet for Combined Cannikin, Long Shot, and Milrow (With Kelp) ................................

$11 \quad$ Scenario 7 - Fish Subsistence Diet for Aleut Culture and Communication Area ..................................F-11

12 Scenario 8 - Mammal Subsistence Diet for Aleut Culture and

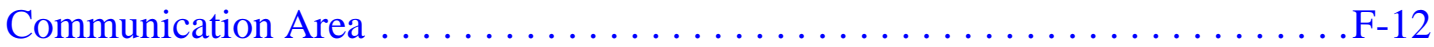

13 Scenario 9 - Commercial Catch Diet for Aleut Culture and Communication Area ................................

A.1 Conceptual Risk Assessment Model and Model Elements . . . . . . . . . . . AF-1

A.2 Locations of Cross-sections for Three Areas of Potential Release. . . . . . . . . AF-2

A.3 Cross-sections of Three Areas of Potential Release . . . . . . . . . . . . . AF-3

A.4 Ocean Currents Around Amchitka Island. . . . . . . . . . . . . . . . . . . . . AF-4

A.5 Predicted Plume at Cannikin Using EPA's CORMIX Model . . . . . . . . . . AF-5 
Number

Title

A.6 Predicted Plume at Long Shot Using EPA's CORMIX Model . . . . . . . . . . . AF-6

A.7 Predicted Plume at Milrow Using EPA's CORMIX Model. . . . . . . . . . . . AF-7

A.8 Predicted Plume at Milrow With Kelp Using EPA's CORMIX Model . . . . . . . AF-8

A.9 Locations of 3-D Volumes for Three Areas of Potential Release . . . . . . . . . AF-9

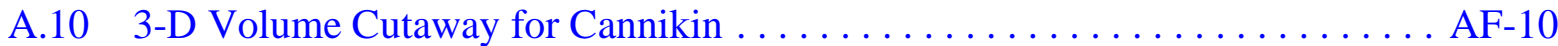

A.11 3-D Volume Cutaway For Long Shot. . . . . . . . . . . . . . AF-11

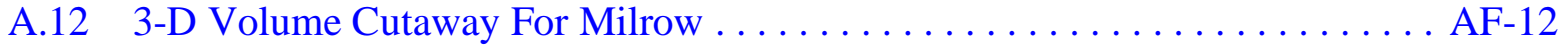

A.13 3-D Volume Cutaway For Milrow With Kelp . . . . . . . . . . . . . AF-13

A.14 Geography Around Aleutian Islands and Area of Aleut Culture and Communication as Well as the Large Offshore Exposure Volume (Inside Dashed Line $). . . \ldots \ldots \ldots \ldots \ldots \ldots \ldots \ldots$. . . . . . . . . . . . . . . . . .

A.15 Reporting Areas for Commercial Fishes $\ldots \ldots \ldots \ldots \ldots \ldots \ldots \ldots \ldots \ldots$ 


\section{List of Tables}

Number

Title

Page

1 Outline of the Calculation Process for Radionuclide Risk Factors . . . . . . . . 5-5

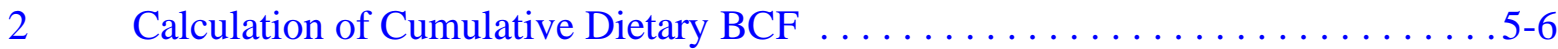

3 Factor to Calculate Radionuclide Concentration in Diet $\ldots \ldots \ldots \ldots \ldots \ldots$. . . . .

4 Annual Ingestion Exposure Factor for all Dietary Items Combined . . . . . . . . 5-8

5 Calculation of Radionuclide Risk Factor for Each Radionuclide. . . . . . . . . . 5-8

6 Radionuclide Risk Factors for Long Shot Exposure Volume. . . . . . . . . . . . . . . 5-9

7 Summary of Maximum Risk Values and the Calendar Year in Which

Those Maximum Values Occur for Each of the 9 Risk Scenarios Based on

Combinations of Groundwater Model Type, Dietary Exposure,

and Location . . . . . . . . . . . . . . . . . . . . . . . . . . . 5-15

8 Maximum Lifetime Risk Values for the Mean Radionuclide Flux

Lifetime Excess Cancer Risks for Each of the 9 Risk Scenarios,

Ranked from Highest to Lowest. . . . . . . . . . . . . . . . . . 5-28

A-1 Radionuclides Selected for Hydrogeological and Risk Assessment Modeling . . A A-5

A-2 Extremes and Statistically-Derived Boundaries and Depth-Defined

Boundaries of Modeled Release Zones for Radionuclides

(Distances From the Groundwater Divide at Amchitka) . . . . . . . . . . . A-8

A-3 Characteristics of Currents Affecting Flow Near Amchitka Island . . . . . . . A-16

A-4 Parameter Values Used in CORMIX Modeling . . . . . . . . . . . . . A-22

A-5 Summary of Dispersion Modeling for Discharges in the Amchitka

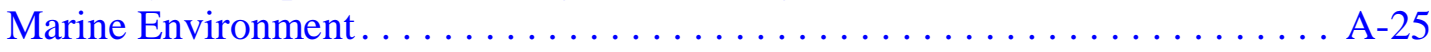

A-6 Subsistence Diet and Commercial Catch Diet Distribution Scenarios

for Amchitka Screening Risk Assessment . . . . . . . . . . . . . . A A-31

A-7 Bioconcentration Factors for Radionuclides by Biota Representing Groups

of Food Sources for Subsistence Consumers and Commercial Catch

Consumers Near Amchitka Island

A-8 Summary of Abundance, Biomass, and Life Expectancy Estimates

for Species Inhabiting Areas Near the Amchitka Coast . . . . . . . . . . . . . A A-41

A-9 Cancer Morbidity Risk Coefficients for Radionuclides

Selected for Screening Risk Assessment Modeling . . . . . . . . . . . . . . . . . A-54 


\section{List of Acronyms and Abbreviations}

3-D Three-dimensional

A/PIA Aleutian/Pribilof Island Association

ADEC Alaska Department of Environmental Conservation

BCF Bioconcentration factor

CEAM Center for Environmental Assessment Modeling

CMRC Cancer morbidity risk coefficient

CORMIX Cornell Mixing Zone Expert System

$\mathrm{cm} / \mathrm{s} \quad$ Centimeters per second

d Day

DCF Dietary concentration factor

DOE U.S. Department of Energy

DRI Desert Research Institute

EPA U.S. Environmental Protection Agency

$\mathrm{ft} \quad$ Foot (Feet)

h Hour

h/d Hours per day

IAEA International Atomic Energy Agency

IEF Ingestion exposure factor

IPHC International Pacific Halibut Commission

kcal/d Kilocalories per day

kg Kilogam

kg/d Kilograms per day

$\mathrm{kg} / \mathrm{km}^{2} \quad$ Kilograms per square kilometer

$\mathrm{kg} / \mathrm{m}^{3} \quad$ Kilograms per cubic meter

km Kilometer

$\mathrm{km}^{2} \quad$ Square kilometers

lbs Pounds

m Mete 


$\begin{array}{ll}\mathrm{mm} & \text { Millimeter } \\ \mathrm{m}^{3} & \text { Cubic meters } \\ \mathrm{m}^{3} / \mathrm{d} & \text { Cubic meters per day } \\ \mathrm{m}^{3} / \mathrm{s} & \text { Cubic meters per second } \\ \mathrm{m} / \mathrm{s} & \text { Meters per second } \\ \mathrm{mT} & \text { Metric ton } \\ \mathrm{mT} / \mathrm{km}{ }^{2} & \text { Metric tons per square kilometer } \\ \mathrm{NMFS} & \text { National Marine Fisheries Service } \\ \mathrm{NNW} & \text { North, northwest } \\ \mathrm{NOAA} & \text { National Oceanic and Atmospheric Administration } \\ \text { ONR } & \text { Office of Naval Research } \\ \mathrm{pCi} & \text { Picocurie } \\ \mathrm{pCi} / \mathrm{d} & \text { Picocuries per day } \\ \text { pCi/L } & \text { Picocuries per liter } \\ \text { pCi/m }{ }^{3} & \text { Picocuries per cubic meter } \\ \text { ROPC } & \text { Radionuclide of potential concern } \\ \text { RRF } & \text { Radionuclide risk factor } \\ \text { SAIC } & \text { Science Applications International Corporation } \\ \text { SSE } & \text { South, southeast } \\ \text { USFWS } & \text { U.S. Fish and Wildlife Service } \\ & \end{array}$




\section{Executive Summary}

Three underground nuclear tests were conducted in the deep subsurface of Amchitka Island in Alaska. The tests (i.e., Long Shot, Milrow, and Cannikin) were conducted in 1965, 1969, and 1971, respectively. There were extensive investigations conducted on these tests and their effect on the environment of the island. Evaluations at the time of testing indicated limited release of radionuclides and absence of risk from the testing; however, as part of its environmental stewardship program, the U.S. Department of Energy (DOE) is reevaluating these sites.

A screening risk assessment of potential radionuclide release into the marine environment is an important part of the DOE's environmental stewardship at Amchitka Island. The risk assessment is one of three interrelated activities: a groundwater model and this screening risk assessment, both of which guide the decisions in the third activity, the site closure plan. Thus, the overall objective of the work is to understand, and subsequently manage, any risk to humans and the environment through a closure and long-term stewardship plan.

The objective of the screening risk assessment, which is the topic of this report, is to predict whether possible releases of radionuclides at the ocean floor would represent potential risks to Native Alaskans by consumption of marine subsistence species. In addition, risks will be predicted for consumers of commercial catches of marine organisms. These risks are calculated beginning with estimates of possible radionuclide release at the seafloor (from a groundwater modeling study), into the seawater, through possible uptake by marine organisms, and finally possible consumption by humans.

Any materials (including radionuclides) in seawater are available for uptake by marine organisms. Some of these marine organisms are important subsistence species for Native Alaskans, including marine mammals, fish, invertebrates, and waterfowl. Important subsistence and commercial fish species include halibut, mackerel, pollock, and salmon.

For this risk assessment, it was assumed that marine mammals and fish are harvested near Amchitka Island and used for food by Native Alaskan's subsistence consumers. Harvested species are typically taken back to the villages, where they may be shared with everyone. These consumers are included in the human exposure compartment of the conceptual model which is 
part of this report. Since a large fraction of their diet is marine species, the Native Alaskans are likely to receive a larger exposure to any radionuclides that may be present in their subsistence foods than would commercial-catch users.

The risk assessment model has 11 elements, progressing from potential release at the seafloor through water and food chains to human intake, and are as follows:

1. Radionuclides of potential concern

2. Locations of releases

3. Seabed substrates

4. Transport by currents

5. Dilution, including plume

6. Human receptors

7. Distribution of diet

8. Bioconcentration factors

9. Fraction of contaminated diet

10. Cancer morbidity risk coefficients

11. Limits to cancer risk

Data for each of these elements were systematically found and synthesized from many sources and represent the best available knowledge. Whenever precise data were lacking, the most conservative data were selected. Conservative assumptions and values were used for radionuclide uptake factors and for marine food ingestion rates by human receptors. The dispersion of material in the marine environment utilized a U.S. Environmental Protection Agency (EPA)-approved model (CORMIX). In addition, the screening level of $1 \times 10^{-6}$ or 1 excess cancer in 1 million is considered by the EPA to be below the level of concern. The end result, as presented in this report, is a highly conservative estimate of potential risks. 
Three dietary exposure scenarios were evaluated using these data and conservative assumptions: two for subsistence diets and one for consumption of commercial catch. Within each of the two subsistence dietary exposure scenarios, two nearshore conditions were evaluated: no kelp at Milrow and with kelp present at Milrow. One offshore condition, the large Aleut culture and communication area, was also evaluated. This results in nine scenarios applied to two groundwater models: the base-case model that represents the best estimate of groundwater transport, and a sensitivity case that reduced matrix diffusion an order of magnitude below the best estimate. These scenarios are as follows:

- Combined source of Cannikin, Long Shot, and Milrow (no kelp); base-case groundwater model and sensitivity-case groundwater model

- Scenario 1: Fish subsistence diet

- Scenario 2: Marine mammal subsistence diet

- Scenario 3: Commercial catch diet

- Combined source of Cannikin, Long Shot, and Milrow (with kelp); base-case groundwater model and sensitivity-case groundwater model

- Scenario 4: Fish subsistence diet

- Scenario 5: Marine mammal subsistence diet

- Scenario 6: Commercial catch diet

- Combined sources of Cannikin, Long Shot, and Milrow (with kelp) in Aleut culture and communication area; base-case groundwater model and sensitivity-case groundwater model

- Scenario 7: Fish subsistence diet

- Scenario 8: Marine mammal subsistence diet

- Scenario 9: Commercial catch diet

Because the radionuclide source data from the Amchitka tests remain classified, the screening risk assessment methods required an innovative approach. The exposure terms were combined to form a radionuclide risk factor which is annual risk per picocurie per day of radionuclide flux. These factors are applied to compute the potential risk. 
The most important result of the Amchitka Island human health screening risk assessment is that the predicted lifetime risk values for the mean radionuclide flux from the 19 radionuclides released from the test detonations in 1965, 1969, and 1971 ranged from approximately 10,000-fold to 1,000,000-fold below EPA's point of departure for risk $\left(1.00 \times 10^{-6}\right)$. Even incorporating considerable uncertainty or conservatism into the calculation of radionuclide flux through groundwater and retaining the conservatism in the risk assessment parameters, the risk is still well below the EPA's lower level of concern. These values were predicted for the 1,000-year period from 1965 through 2965 for all nine risk scenario combinations.

In summary, the screening risk assessment, using conservative data and assumptions, shows potential risk levels to be well below the EPA's most conservative risk threshold for both subsistence users and commercial-catch consumers. 


\subsection{Introduction}

Three underground nuclear tests were conducted in the deep subsurface of Amchitka Island in Alaska. The tests (i.e., Long Shot, Milrow, and Cannikin) were conducted in 1965, 1969, and 1971, respectively. There were many extensive investigations conducted on these tests and their effect on the environment of the island. Evaluations at the time of testing indicated limited release of radionuclides and absence of risk from the testing; however, as part of its environmental stewardship program, the U.S. Department of Energy (DOE) is reevaluating these sites.

The current risk investigation focuses on the possible movement of radionuclides from the underground test chambers, through geological formations, to the ocean floor. From the ocean floor, radionuclides could further travel into the marine waters and into marine organisms. Some of these marine organisms make up the subsistence diet for Native Alaskans living in the Aleutian Islands, while some are a part of the abundant commercial catch from the Northern Pacific Ocean. The marine organisms could take up radionuclides from the marine water, thereby exposing the Native Alaskans to radionuclides as a result of ingesting the organisms. Exposure to ionizing radiation from ingested radionuclides carries with it the potential for harm (e.g., cancer).

Whether such exposure could happen will be determined by a two-part investigation that examines the following: (1) the possible movement of radionuclides in the geological formations to the ocean floor (Hassan et al., 2001) and (2) the possible movement of radionuclides in the water and food webs near Amchitka Island. There are interim work products for both parts (e.g., IT Corporation [1999] presented information pertinent to the risk assessment). The IT Corporation report describes how the second part of the investigation, the screening risk assessment, will be calculated from potential radionuclide releases at the seafloor, through the food web, to subsistence users and commercial consumers. From this, the predicted cancer risks from the potential radionuclide releases can be calculated.

\section{Document Organization}

This report includes seven primary sections and one appendix. The figures called out in the text of the main document are provided after Section 8.0, References. Likewise, the figures called out in Appendix A are provided after Section A.15.0, References. 


\subsection{Objectives}

The risk assessment is an important part of the DOE's environmental stewardship at Amchitka Island. Regarding the marine or ocean part of the system, there are three interrelated activities: a groundwater model and this screening risk assessment, both of which guide the decisions in the third activity, the site closure plan. Thus, the overall objective of the work is to understand, and subsequently manage, any risk to humans and the environment through a closure plan.

The objective of the screening risk assessment, which is the topic of this report, is to methodically predict whether possible releases of radionuclides at the ocean floor would represent potential risks to Native Alaskans by consumption of marine subsistence species. Also, risks will be predicted for consumers of commercial catches of marine organisms. These risks are calculated beginning with estimates of possible radionuclide seepage at the seafloor into the seawater (from the hydrogeologic study) through possible uptake by marine organisms, and finally possible consumption by humans. 


\subsection{Setting}

The Aleutian Islands rise from the Aleutian Ridge, an elongated, curved rim that rises above the seafloor, extends westward from the Bering Shelf, and separates the Pacific Ocean on the south from the Bering Sea on the north (Figure 1). Amchitka Island, one of the Rat Islands situated near the center of the Aleutian chain, is a narrow, elliptically-shaped land mass oriented south, southeast (SSE) - north, northwest (NNW) along its major axis.

Amchitka Island was the site of three underground nuclear tests, at depths ranging from 2,300 to 5,875 feet (ft). Each test created a cavity around the center of the detonation and a chimney of fragmented and collapsed rock above. The cavities and the chimneys contain radioactive byproducts of the nuclear detonation; some of these products were trapped in glass, which was created when the rock melted by the detonations cooled and hardened.

The rock beneath the island is saturated with groundwater, and the water table is very near the land surface. Because the test cavities are in the saturated zone, there is a potential for radionuclides to migrate in groundwater. Given the island setting, groundwater migrates to the ocean floor, where it mixes with seawater. Therefore, there is a potential for radionuclides to migrate from the test cavities to seawater.

The waters around Amchitka Island (parts of the Pacific Ocean and the Bering Sea) contain abundant marine species, including various kinds of fish and marine mammals. These fish and mammals make up a large part of the subsistence diet of Native Alaskans who live in the Aleutians. The conceptual model (discussed in Section 4.0) briefly describes the potential flow of radionuclides from the ocean floor, to marine organisms, and ultimately to human subsistence consumers or consumers of commercial catches. 


\subsection{Conceptual Model}

The conceptual model of transport of radionuclides from the ocean floor to human consumers is shown in Figure 2. From the ocean floor, radionuclides can potentially travel into the marine waters, where they would be moved by currents and diluted. This is indicated by the "Ocean Water and Currents" compartment of the conceptual model diagram.

Any materials (including radionuclides) in seawater are available for uptake by marine organisms. Some of these marine organisms are important subsistence species for Native Alaskans, such as Steller sea lions, harbor seals, northern fur seals, mussels and clams, crabs, octopus, pogie eggs and other fish eggs, sea urchins, migratory water fowl, bird eggs, and various species of fish. Important subsistence and commercial fish species include halibut, mackerel, pollock, and salmon. These species are included in the "Marine Food Webs" compartment of the conceptual model diagram (Figure 2). Some of these species reside in the upper depths of the ocean, while others live or feed mainly on the bottom. For example, sea urchins live on the ocean floor and sea otters dive to the bottom to prey on them, and crabs and octopus that live on the bottom are preyed upon by young halibut that live in deep water. The typical depth ranges of several of the subsistence species are shown in Figure 3. Migratory waterfowl are only briefly exposed to food from Amchitka sources; therefore, they are not considered further in this analysis.

Marine mammals and fish may be harvested near Amchitka Island and used for food by Native Alaskans. Also, some marine species may travel from the vicinity of Amchitka and be harvested in other areas. Harvested species are typically taken back to the villages, where they may be shared with everyone. These consumers are included in the "Human Exposure" compartment of the conceptual model diagram (Figure 2). Since a large fraction of their diet is marine species, the Native Alaskans are likely to receive a larger exposure to potential radionuclides in marine species than commercial-catch users. 


\subsection{Steps of the Screening Risk Assessment}

There are three main components of the overall site closure plan: the groundwater model, the screening risk assessment, and the closure plan itself (Figure 4). The activities required to prepare the risk assessment includes the following main steps identified in Section 5.1 and substeps identified in Section 5.2.

\subsection{Four Main Steps of Screening Risk Assessment}

The screening risk assessment has four main steps:

A. Use method paper: The method paper outlined the proposed procedures to be followed during the risk assessment. This has already been completed in the form of progress reports (IT, 1999) and the work developed earlier in 2000 through conversations with DOE, the Alaska Department of Environmental Conservation (ADEC), the U.S. Fish and Wildlife Service (USFWS), and the Aleutian/Pribilof Island Association (A/PIA).

B. Establish technical basis, including best professional practices: This report describes the technical basis for the risk assessment (as outlined in the method paper), and includes revisions to refine the exposure volumes, diets, and other technical parameters. The five substeps, each of which has its own work elements, are listed in Section 5.2.

C. Prepare screening risk assessment report: This constitutes the remainder of the current work.

\section{Respond to review comments}

Main activity (Step B) is further divided into substeps that flow into the site closure plan. Note that detailed explanations of each of the inputs or elements to the screening risk assessment are found in Attachment A to this report.

\subsection{Five Substeps of Screening Risk Assessment (Step B)}

The five substeps necessary for defining the technical basis for the risk assessment (Main Step B) are briefly described below:

1. Define conditions: This means that the radionuclides of potential concern (ROPCs) are identified, locations of potential release are predicted, ocean substrates are defined, current velocity and direction are known, and dilution is calculated. 
2. Set exposure scenarios: This refers to the volume of water available for dilution. There are two proposed volumes of marine water considered in this report: small (i.e., in the close vicinity of the potential release) and large (i.e., a large portion of the Bering Sea).

3. Select receptor scenarios: This refers to the human receptors that will be used and the diets that will be assumed. Both subsistence and commercial-catch exposures will be assumed.

4. Input data for model elements into equations: This refers to selection of the bioconcentration factors (BCFs), cancer morbidity risk coefficients (CMRCs) (formerly termed cancer slope factors), and dietary consumption rates.

5. Show and discuss risk per unit of radionuclide released: This is a graphical representation and detailed discussion of risk posed by the various radionuclides. Tables 1 through 5 show the process by which a risk factor will be calculated for each radionuclide in each scenario. This factor is called the radionuclide risk factor (RRF) because it gives the risk from one unit of flux. Flux is the rate of release of material, in this case radionuclides (i.e., 1 picocurie [pCi] of each radionuclide per day). The RRF will be multiplied by the predicted flux to calculate the risk from that radionuclide under that scenario. Tables 1 through 5 show not only the chain of computation but also provide example outputs. The resulting risk values are included in Figures 5 through 13.

\subsection{Eleven Elements}

As explained earlier, most substeps have one or more types of inputs or elements associated with the conceptual model. These 11 elements are:
1. ROPCs
2. Locations of releases
3. Seabed substrates
4. Transport by currents
5. Dilution, including plume
6. BCFs
7. Human receptors
8. Distribution of diet
9. Fraction of contaminated diet
10. CMRCs
11. Limits to cancer risk

An expanded treatment of each element is provided in Appendix A. A brief description is provided for each element followed by an exposition of current knowledge and the implementation for using the data per the above steps and substeps. 


\subsection{Anticipated Exposure Volumes}

The two relative sizes of exposure volumes of sea water were identified in Section 5.2. Predicted releases from each site into a small volume were combined to calculate risk among scenarios. Additionally, combined releases into a volume approximately the size of the Aleut culture and communication area were used to calculate overall risk. This section further explains and justifies these volumes.

\subsubsection{Small Volumes}

The small volumes are modeled plumes in which substances potentially released to the ocean floor are dispersed. The groundwater model predicts releases over a range of distances from shore. For plume modeling, it was assumed that the releases occur at a point midway between the $5^{\text {th }}$ and the $95^{\text {th }}$ percentiles of the distances predicted by the groundwater model. Those distances are approximately 3.0 kilometers $(\mathrm{km})$ from the shoreline for Cannikin, $2.0 \mathrm{~km}$ for Long Shot, and $2.0 \mathrm{~km}$ for Milrow.

Depthwise, the small volumes are located in a range from the shoreline at $0 \mathrm{ft}$ deep to the predicted outer limit of releases, near the 300-ft depth contour for Cannikin in the Bering Sea and Milrow in the Pacific Ocean, and around $180 \mathrm{ft}$ for Long Shot in the Bering Sea. This represents a horizontal expanse of about $3.8 \mathrm{~km}$ for Cannikin, about $4.4 \mathrm{~km}$ for Long Shot, and about $5.5 \mathrm{~km}$ for Milrow. The size of each small volume was calculated by using a dispersion model that takes into account the location of the release, wave action, and currents. For more details, see the element on dilution, including plume, in Appendix A, Section A.6.0.

One variant for Milrow assumes that kelp occupies the entire volume and retards the current by one-third. For details, see the element on seabed substrates in Appendix A, Section A.4.0.

\subsubsection{Large Volume}

A large volume of sea water was also used for dilution and exposure modeling. This volume represents the Aleut culture and communication area. Thousands of square miles of surface and about half-a-million cubic kilometers of marine waters are contained in this very large volume. For details, see the element on dilution, including plume, in Appendix A. 


\subsection{Calculational Process and Expected Output}

The standard method of performing a risk assessment for radionuclides in water is to begin with concentrations of constituents (i.e., radionuclides in seawater), calculate the estimated concentrations in the diet of human receptors by applying water-to-biota uptake factors, calculating the lifetime dose by multiplying the concentration by the food ingestion rate, and computing the risk by using CMRCs expressed as risk per $\mathrm{pCi}$ of radionuclide exposure during a lifetime. Risks from individual radionuclides can be added to compute a cumulative risk.

To estimate the concentration in seawater, it is necessary to know the flux of individual radionuclides into the sea. However, that information is classified. Therefore, neither the concentration nor the flux of radionuclides is stated in this report. As a result, the risk assessment presented in this report includes several unclassified terms. These terms are combined to form the RRF, which is the annual risk per picocurie per day $(\mathrm{pCi} / \mathrm{d})$ of radionuclide flux:

$$
\mathrm{RRF}=\mathrm{BCF} \times \mathrm{DIL} \times \mathrm{FrC} \times \mathrm{AIR} \times \mathrm{CMRC},
$$

Where:

$$
\begin{aligned}
& \mathrm{RRF}=\text { Radionuclide risk factor (cancer risk/year per pCi/d) } \\
& \mathrm{BCF}=\text { Bioconcentration factor (liters per kilogram) } \\
& \mathrm{DIL}=\text { Dilution factor }(\mathrm{pCi} / \text { liter per pCi/day }=\text { days per liter) } \\
& \mathrm{FrC}=\text { Fraction contaminated } \\
& \mathrm{AIR}=\text { Annual food ingestion rate (kilogram/year) } \\
& \mathrm{CMRC}=\text { Cancer morbidity risk coefficient }(\text { lifetime risk/pCi) }
\end{aligned}
$$

The terms of this equation are illustrated and explained in Tables 1 through 5 and the accompanying text. The RRF is analogous to the CMRC, but the RRF relates risk to daily flux rather than to a lifetime. The RRF can be used to make calculations of the risk from the hydrogeologically predicted radionuclide flux.

The RRF can also be used to handle many radionuclides at the same time and to calculate cumulative risks. Because the unit of risk is the same for all radionuclides (i.e., lifetime excess cancer risk), risks can be summed for a few or all radionuclides. The RRFs will be calculated for each radionuclide in each diet scenario. The RRFs will be applied to the output of groundwater modeling and to calculate 
the cumulative risk for each exposure scenario. The cumulative risks will be compared to a $10^{-6}$ risk threshold as described in Section 5.7, "Application of Calculational Process." This information will be used in the site closure report.

Table 1 outlines the groups of calculations that were done. Tables 2 through 5 present the steps in each set of calculations. Examples are also given in Tables 2 through 5 using the radionuclides tritium, strontium-90, and cesium-137. These radionuclides were chosen for illustrative purposes because estimates of their yields had been used for preliminary studies. Table 6 presents an example of the RRFs for Long Shot that were used to calculate radionuclide flux.

Table 1

Outline of the Calculation Process for Radionuclide Risk Factors

\begin{tabular}{|c|c|c|c|c|}
\hline Radionuclide & $\begin{array}{c}\text { Cumulative Dietary } \\
\text { Bioconcentration } \\
\text { Factor } \\
\text { (Table 2) }\end{array}$ & $\begin{array}{l}\text { Factor to Calculate } \\
\text { Radionuclide } \\
\text { Concentration } \\
\text { in Diet } \\
\text { (Table 3) }\end{array}$ & $\begin{array}{l}\text { Annual Ingestion } \\
\text { Exposure Factor } \\
\text { for All Dietary } \\
\text { Items Combined } \\
\text { (Table 4) }\end{array}$ & $\begin{array}{l}\text { Calculation of } \\
\text { Radionuclide Risk } \\
\text { Factor for Each } \\
\text { Radionuclide } \\
\text { (Table 5) }\end{array}$ \\
\hline $\begin{array}{l}\text { Tritium } \\
\text { Carbon-14 } \\
\text { Chlorine-36 } \\
\text { Strontium-90 } \\
\text { Yttrium-90 } \\
\text { lodine-129 } \\
\text { Technetium-99 } \\
\text { Cesium-137 } \\
\text { Samarium-151 } \\
\text { Europium-152 } \\
\text { Gadolinium-152 } \\
\text { Uranium-234 } \\
\text { Uranium-236 } \\
\text { Uranium-238 } \\
\text { Neptunium-237 } \\
\text { Plutonium-239 } \\
\text { Plutonium-240 } \\
\text { Plutonium-241 } \\
\text { Americium-241 }\end{array}$ & $\begin{array}{l}\text { Computes a } \\
\text { cumulative dietary } \\
\text { bioconcentration factor } \\
\text { for each scenario by } \\
\text { summing the product } \\
\text { of dietary fractions and } \\
\text { BCFs. }\end{array}$ & $\begin{array}{l}\text { Combines cumulative } \\
\text { dietary } \\
\text { bioconcentration } \\
\text { factor with dilution } \\
\text { factor and fraction of } \\
\text { diet that is } \\
\text { contaminated to } \\
\text { calculate dietary } \\
\text { concentration factor. }\end{array}$ & $\begin{array}{l}\text { Combines dietary } \\
\text { concentration } \\
\text { factor with annual } \\
\text { ingestion rate to } \\
\text { yield annual } \\
\text { ingestion exposure } \\
\text { factor for each } \\
\text { radionuclide. }\end{array}$ & $\begin{array}{l}\text { Combines annual } \\
\text { ingestion exposure } \\
\text { factor with cancer } \\
\text { morbidity risk } \\
\text { coefficient to yield } \\
\text { a radionuclide } \\
\text { cancer risk factor } \\
\text { for each } \\
\text { radionuclide. The } \\
\text { radionuclide risk } \\
\text { factor is multiplied } \\
\text { by the annual } \\
\text { average daily } \\
\text { radionuclide flux to } \\
\text { yield the annual } \\
\text { excess cancer risk. }\end{array}$ \\
\hline
\end{tabular}

The process for selecting radionuclides to be included in this risk assessment is described in Section A.2.0. The cumulative BCF is used to calculate the concentration of radionuclides in the contaminated portion of the diet from the concentration in seawater. The steps in the cumulative BCF calculation are presented in Table 2. These steps are to multiply the BCF for each radionuclide and each food item by the fraction of the diet represented by that food item and sum the results. 
Table 2

Calculation of Cumulative Dietary BCF

\begin{tabular}{|c|c|c|c|c|}
\hline \multirow{2}{*}{ Dietary item } & \multirow{2}{*}{ Parameter } & \multicolumn{3}{|c|}{$\begin{array}{l}\text { Example Radionuclides } \\
\text { (19 radionuclides are considered) }\end{array}$} \\
\hline & & Tritium & Strontium-90 & Cesium-137 \\
\hline Marine fish & $\begin{array}{l}\text { Fraction of marine fish in } \text { diet }^{a} \\
\text { Published } B C F^{b}(\mathrm{~L} / \mathrm{kg}) \\
\text { Partial dietary } B C F^{\mathrm{c}}(\mathrm{L} / \mathrm{kg})\end{array}$ & $\begin{array}{l}0.9 \\
1.0 \\
0.9\end{array}$ & $\begin{array}{c}0.9 \\
0.926 \\
0.833\end{array}$ & $\begin{array}{c}0.9 \\
100 \\
90\end{array}$ \\
\hline Marine mammals & $\begin{array}{l}\text { Fraction of marine mammals in diet }{ }^{\mathrm{a}} \\
\text { Published } \mathrm{BCF}^{\mathrm{b}}(\mathrm{L} / \mathrm{kg}) \\
\text { Partial dietary } B C F^{\mathrm{c}}(\mathrm{L} / \mathrm{kg})\end{array}$ & $\begin{array}{l}0.05 \\
1.0 \\
0.05\end{array}$ & $\begin{array}{l}0.05 \\
1.0 \\
0.05\end{array}$ & $\begin{array}{l}0.05 \\
100 \\
5.0\end{array}$ \\
\hline Crustaceans & $\begin{array}{l}\text { Fraction of crustaceans in } \text { diet }^{a} \\
\text { Published } B C F^{b}(L / k g) \\
\text { Partial dietary } B C F^{c}(L / k g)\end{array}$ & $\begin{array}{l}0.01 \\
1.0 \\
0.01\end{array}$ & $\begin{array}{l}0.01 \\
2.0 \\
0.02\end{array}$ & $\begin{array}{c}0.01 \\
30 \\
0.3\end{array}$ \\
\hline Mollusks & $\begin{array}{l}\text { Fraction of mollusks in } \text { diet }^{\mathrm{a}} \\
\text { Published } \mathrm{BCF}^{\mathrm{b}}(\mathrm{L} / \mathrm{kg}) \\
\text { Partial dietary } \mathrm{BCF}^{\mathrm{c}}(\mathrm{L} / \mathrm{kg})\end{array}$ & $\begin{array}{l}0.01 \\
1.0 \\
0.01\end{array}$ & $\begin{array}{c}0.01 \\
10 \\
0.1\end{array}$ & $\begin{array}{c}0.01 \\
30 \\
0.3\end{array}$ \\
\hline $\begin{array}{l}\text { Plants (including } \\
\text { kelp) }\end{array}$ & $\begin{array}{l}\text { Fraction of plants in diet }{ }^{\mathrm{a}} \\
\text { Published } \mathrm{BCF}^{\mathrm{b}}(\mathrm{L} / \mathrm{kg}) \\
\text { Partial dietary } \mathrm{BCF}^{\mathrm{c}}(\mathrm{L} / \mathrm{kg})\end{array}$ & $\begin{array}{c}0.01 \\
1.0 \\
0.01\end{array}$ & $\begin{array}{c}0.01 \\
5.0 \\
0.05\end{array}$ & $\begin{array}{c}0.01 \\
50 \\
0.5\end{array}$ \\
\hline $\begin{array}{c}\text { Other } \\
\text { (nonmarine) food }\end{array}$ & $\begin{array}{l}\text { Fraction of other foods in diet }{ }^{\mathrm{a}} \\
\mathrm{CF}(0 \text { for non-marine foods }) \\
\text { Partial dietary } \mathrm{BCF}^{\mathrm{c}}(\mathrm{L} / \mathrm{kg})\end{array}$ & $\begin{array}{c}0.02 \\
0 \\
0\end{array}$ & $\begin{array}{c}0.02 \\
0 \\
0\end{array}$ & $\begin{array}{c}0.02 \\
0 \\
0\end{array}$ \\
\hline Total diet & Cumulative dietary $\mathrm{BCF}^{\mathrm{d}}(\mathrm{L} / \mathrm{kg})$ & 0.98 & 1.05 & 96.1 \\
\hline
\end{tabular}

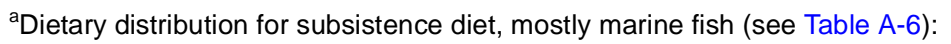

$\begin{array}{ll}\text { Fish } & 0.9 \\ \text { Mammals } & 0.05 \\ \text { Crustaceans } & 0.01 \\ \text { Mollusks } & 0.01 \\ \text { Plants } & 0.01 \\ \text { Other (non-marine) } & 0.02\end{array}$

${ }^{\mathrm{b}}$ From the appendix to the report, Table A-7

${ }^{\circ}$ Dietary fraction multiplied by BCF

${ }^{d}$ Sum of partial dietary BCFs

$\mathrm{L} / \mathrm{kg}=$ Liters per kilogram

The cumulative dietary BCFs are multiplied by a dilution factor (Section A.6.2.2) and the fraction of the diet that is assumed to be contaminated (Section A.10.0). This computation is illustrated in Table 3.

Table 4 uses the output from Table 3 (dietary concentration factor [DCF]), the average daily ingestion rate, and a conversion factor to convert from ingestion per day to ingestion per year as inputs. The DCF was multiplied by the average daily ingestion rate (assumed to be 1.25 kilogram per day 
Table 3

Factor to Calculate Radionuclide Concentration in Diet

\begin{tabular}{|c|c|c|c|c|}
\hline Radionuclide & $\begin{array}{c}\text { Cumulative BCFs } \\
(\mathrm{L} / \mathbf{k g})\end{array}$ & $\begin{array}{l}\text { Dilution Factor }{ }^{a} \\
\qquad(d / L)\end{array}$ & $\begin{array}{l}\text { Fraction of Diet } \\
\text { That is } \\
\text { Contaminated }^{\mathrm{b}}\end{array}$ & $\begin{array}{c}\text { Dietary } \\
\text { Concentration Factor } \\
(\mathrm{d} / \mathrm{kg})\end{array}$ \\
\hline $\begin{array}{l}19 \text { Selected } \\
\text { radionuclides }\end{array}$ & $\begin{array}{l}\text { Table 2: Dietary } \\
\text { fraction of each item } \\
\text { is multiplied by the } \\
\text { bioconcentration } \\
\text { factor of each item, } \\
\text { and the products are } \\
\text { summed. }\end{array}$ & $\begin{array}{l}\text { DIL converts } \\
\text { radionuclide flux } \\
(\mathrm{pCi} / \mathrm{d}) \text { to } \\
\text { radionuclide } \\
\text { concentration in } \\
\text { water }(\mathrm{pCi} / \mathrm{L}) \text {. }\end{array}$ & $\begin{array}{l}\text { Fraction of diet that } \\
\text { is contaminated } \\
\text { (FrC) is calculated } \\
\text { from the sizes of the } \\
\text { plume and the } \\
\text { fishing or hunting } \\
\text { area and the density } \\
\text { of marine food. }\end{array}$ & $\begin{array}{l}\text { Cumulative BCF } \\
\text { multiplied by the } \\
\text { dilution factor and the } \\
\text { fraction of diet that is } \\
\text { contaminated: } \mathrm{DCF} \\
(\mathrm{d} / \mathrm{kg})=\sum(\mathrm{DF} \times \mathrm{BCF}) \times \\
\text { DIL } \times \text { FrC. }\end{array}$ \\
\hline $\begin{array}{l}\text { Example: } \\
\text { Tritium } \\
\text { Strontium-90 } \\
\text { Cesium-137 }\end{array}$ & $\begin{array}{l}0.98 \\
1.05 \\
96.1\end{array}$ & $\begin{array}{l}1.11 \mathrm{E}-11 \\
1.11 \mathrm{E}-11 \\
1.11 \mathrm{E}-11\end{array}$ & $\begin{array}{l}3.6 \mathrm{E}-04 \\
3.6 \mathrm{E}-04 \\
3.6 \mathrm{E}-04\end{array}$ & $\begin{array}{l}3.90 \mathrm{E}-15 \\
4.18 \mathrm{E}-15 \\
3.83 \mathrm{E}-13\end{array}$ \\
\hline
\end{tabular}

\footnotetext{
$\mathrm{BCF}=$ Bioconcentration factor

DIL = Dilution factor

$\mathrm{FrC}=$ Fraction of diet that is contaminated

$\mathrm{DCF}=$ Dietary concentration factor

$\mathrm{DF}=$ Fraction of diet made up by each dietary item

$\mathrm{pCi} / \mathrm{d}=$ Picocuries per day

$\mathrm{pCi} / \mathrm{L}=$ Picocuries per liter

$\mathrm{L} / \mathrm{kg}=$ Liters per kilogram

$d / L=$ Day per liter

${ }^{a}$ Calculated for the Long Shot plume as described in Attachment A, Section A.6.2.2.

${ }^{b}$ Calculated as described in Attachment A, Section A.10.4.
}

[kg/day] for Native Alaskans and $0.86 \mathrm{~kg} /$ day for consumers of commercial catch; see Section A.8.2) and the conversion factor of 365 days per year to yield the annual ingestion exposure factor (IEF). The output of Table 4 constitutes input to Table 5.

Table 5 uses the annual ingestion exposure factor from Table 4 along with the CMRC to calculate the RRF. The CMRC is a factor that is used to predict the annual contribution to the probability of morbidity from cancer resulting from exposure to radiation over a 70-year lifetime. The CMRC is adjusted for dietary absorption of ingested radionuclides and for variability of sensitivity to carcinogens during different life stages (see Attachment A, Section A.11.0). Therefore, it accounts for exposure of both children and adults.

As an example, RRFs for the nineteen radionuclides and the three diet scenarios for the Long Shot exposure volume are presented in Table 6. 
Table 4

Annual Ingestion Exposure Factor for all Dietary Items Combined

\begin{tabular}{|c|c|c|c|}
\hline Radionuclide & $\begin{array}{l}\text { Dietary } \\
\text { Concentration } \\
\text { Factor }(\mathbf{d} / \mathbf{k g})\end{array}$ & Annual Ingestion Rate (kg/y) & $\begin{array}{c}\text { Calculation of Annual } \\
\text { Ingestion Exposure Factor } \\
(\mathrm{d} / \mathrm{y})\end{array}$ \\
\hline $\begin{array}{l}19 \text { Selected } \\
\text { radionuclides }\end{array}$ & $\begin{array}{l}\text { Dietary concentration } \\
\text { factor from Table } 3 \text {. }\end{array}$ & $\begin{array}{l}\text { Annual ingestion rate (daily ingestion rate } \\
\text { multiplied by days/year): } \\
\text { AIR }(\mathrm{kg} / \mathrm{y})=\mathrm{IR}(\mathrm{kg} / \mathrm{d}) \times 365.25 \text { days per } \\
\text { year }=1.25 \mathrm{~kg} / \mathrm{d} \times 365.25 \mathrm{~d} / \mathrm{y}=4.55 \mathrm{E}+02 \\
\text { year. }\end{array}$ & $\begin{array}{l}\text { Annual ingestion exposure } \\
\text { factor is the dietary } \\
\text { concentration factor } \\
\text { multiplied by annual } \\
\text { ingestion rate: } \\
(\mathrm{d} / \mathrm{y})=\mathrm{DCF}(\mathrm{d} / \mathrm{kg}) \times \mathrm{AIR} \\
(\mathrm{kg} / \mathrm{y}) \text {. When multiplied by } \\
\text { flux, this yields the annual } \\
\text { dietary exposure (pCi/year). }\end{array}$ \\
\hline $\begin{array}{l}\text { Example: } \\
\text { Tritium } \\
\text { Strontium-90 } \\
\text { Cesium-137 }\end{array}$ & $\begin{array}{l}3.90 \mathrm{E}-15 \\
4.18 \mathrm{E}-15 \\
3.83 \mathrm{E}-13\end{array}$ & $\begin{array}{l}4.55 \mathrm{E}+02 \\
4.55 \mathrm{E}+02 \\
4.55 \mathrm{E}+02\end{array}$ & $\begin{array}{l}1.78 \mathrm{E}-12 \\
1.90 \mathrm{E}-12 \\
1.74 \mathrm{E}-10\end{array}$ \\
\hline
\end{tabular}

$\mathrm{d} / \mu \mathrm{g}=$ Day per kilogram

$\mathrm{kg} / \mathrm{y}=$ Kilogram per year

AIR = Annual ingestion rate

$\mathrm{IR}=$ Ingestion rate

Table 5

Calculation of Radionuclide Risk Factor for Each Radionuclide

\begin{tabular}{|c|c|c|c|}
\hline Radionuclide & $\begin{array}{l}\text { Annual Ingestion } \\
\text { Exposure Factor } \\
(\mathrm{d} / \mathrm{y})\end{array}$ & $\begin{array}{l}\text { Cancer Morbidity } \\
\text { Risk Coefficient } \\
\text { (cancer risk/pCi) }\end{array}$ & $\begin{array}{l}\text { Calculation of Radionuclide Risk Factor } \\
\text { (cancer risk/y per pCi/d) }\end{array}$ \\
\hline $\begin{array}{l}19 \text { Selected } \\
\text { radionuclides }\end{array}$ & $\begin{array}{l}\text { Annual ingestion } \\
\text { exposure factor } \\
\text { from Table } 4 .\end{array}$ & $\begin{array}{l}\text { Cancer morbidity risk } \\
\text { coefficient is the } \\
\text { probability of excess } \\
\text { cancers per pCi of } \\
\text { radionuclide ingested } \\
\text { in a } 70 \text {-year lifetime } \\
\text { (excess cases/pCi). } \\
\text { Source of CMRCs is } \\
\text { EPA }(2001) \text {. }\end{array}$ & $\begin{array}{l}\text { Radionuclide risk factor for lifetime excess cancer } \\
\text { risk is the annual ingestion exposure factor } \\
\text { multiplied by the cancer morbidity risk coefficients: } \\
\text { RRF }[(\text { excess cases/y)/(pCi/d)] = IEF (d/year) } x \\
\text { CMRC (excess cases } / p C i) \text {. When multiplied by } \\
\text { flux (pCi/d), yields annual contribution to } \\
\text { lifetime excess cancer risk (excess cases per } \\
\text { year). }\end{array}$ \\
\hline $\begin{array}{l}\text { Examples: } \\
\text { Tritium } \\
\text { Strontium-9 } \\
\text { Cesium-137 }\end{array}$ & $\begin{array}{l}1.78 \mathrm{E}-12 \\
1.90 \mathrm{E}-12 \\
1.74 \mathrm{E}-10\end{array}$ & $\begin{array}{l}6.51 \mathrm{E}-14 \\
9.53 \mathrm{E}-11 \\
3.74 \mathrm{E}-11\end{array}$ & $\begin{array}{l}1.16 \mathrm{E}-25 \\
1.31 \mathrm{E}-22 \\
6.52 \mathrm{E}-21\end{array}$ \\
\hline
\end{tabular}

$d / y=$ Day per year 
Table 6

Radionuclide Risk Factors for Long Shot Exposure Volume

\begin{tabular}{|c|c|c|c|}
\hline \multirow[b]{2}{*}{ Radionuclide } & \multicolumn{3}{|c|}{ Diet for Exposure Scenarios } \\
\hline & $\begin{array}{c}\text { Subsistence } \\
\text { Consumption, } \\
\text { Mostly } \\
\text { Marine Fish } \\
\text { [(risk/y)/(pCi/d)] }\end{array}$ & $\begin{array}{c}\text { Subsistence } \\
\text { Consumption, } \\
\text { Mostly } \\
\text { Marine Mammals } \\
{[(\text { risk/y)/(pCi/d)] }}\end{array}$ & $\begin{array}{c}\text { Consumption } \\
\text { of Commercial } \\
\text { Catch } \\
{[(\text { risk } / y) /(p C i / d)]}\end{array}$ \\
\hline Tritium & $1.16 \mathrm{E}-25$ & 1.16E-25 & $3.60 \mathrm{E}-27$ \\
\hline Carbon-14 & $6.14 \mathrm{E}-20$ & $6.15 E-21$ & 2.34E-21 \\
\hline Chlorine-36 & 3.07E-24 & $6.85 E-24$ & 8.88E-26 \\
\hline Strontium-90 & $1.31 \mathrm{E}-22$ & $1.39 E-22$ & $7.40 \mathrm{E}-24$ \\
\hline Yttrium-90 & $2.31 \mathrm{E}-21$ & $1.50 \mathrm{E}-21$ & $4.21 \mathrm{E}-22$ \\
\hline Technetium-99 & 4.17E-22 & $2.81 E-22$ & $6.51 E-23$ \\
\hline lodine-129 & 1.13E-20 & $7.42 \mathrm{E}-21$ & $1.78 \mathrm{E}-22$ \\
\hline Cesium-137 & $6.52 \mathrm{E}-21$ & $6.52 E-21$ & 1.67E-22 \\
\hline Samarium-151 & 7.96E-22 & 2.73E-22 & 4.46E-23 \\
\hline Europium-152 & $6.04 \mathrm{E}-21$ & $2.65 E-21$ & $4.98 \mathrm{E}-22$ \\
\hline Gadolinium-152 & $3.86 \mathrm{E}-20$ & $1.22 \mathrm{E}-20$ & $2.51 \mathrm{E}-21$ \\
\hline Uranium-234 & 3.99E-22 & $2.52 E-22$ & $2.78 \mathrm{E}-23$ \\
\hline Uranium-236 & 3.77E-22 & 2.39E-22 & 2.63E-23 \\
\hline Uranium-238 & $3.61 \mathrm{E}-22$ & 2.29E-22 & $2.52 E-23$ \\
\hline Neptunium-237 & $2.18 \mathrm{E}-21$ & $9.05 E-22$ & 2.83E-22 \\
\hline Plutonium-239 & $2.81 E-20$ & $1.82 E-20$ & $3.43 E-21$ \\
\hline Plutonium-240 & 2.81E-20 & $1.82 \mathrm{E}-20$ & $3.43 E-21$ \\
\hline Plutonium-241 & 3.69E-22 & 2.39E-22 & 4.49E-23 \\
\hline Americium-241 & 8.02E-20 & $6.99 E-20$ & $1.44 \mathrm{E}-20$ \\
\hline
\end{tabular}

Risk/y = Risk per year 
The RRF for each radionuclide was multiplied by the daily flux for that radionuclide to calculate the annual contribution to lifetime risk of excess cancer morbidity. Risks for all radionuclides at all locations were then summed to yield a total daily risk.

The risk calculation includes an exposure period of 70 years. The flux is not constant. Instead, it increases with time to a maximum and then decreases again; therefore, the exposure similarly increases to a maximum and decreases again. As a result, the calculated lifetime cancer risk depends on when the exposure begins and ends. For the risk evaluation, annual risks were summed for overlapping 70-year periods beginning at the first detonation and continuing for 1,000 years. Thus, the reported risks were a 70-year sum where the first reported value is the risk from year 0 to year 70, the second is the risk from year 1 to year 71, and so forth.

Three exposure scenarios were analyzed for each combination of sites (see Section 5.6). Each scenario was analyzed by computing the RRF and the annual ingestion exposure factor. From those results, the lifetime risks for exposure of 70 years duration were calculated.

\subsection{Risk Scenarios}

Three dietary exposure scenarios were applied, two for subsistence diets and one for consumption of commercial catch. Within each of the two subsistence dietary exposure scenarios, there are two conditions: no kelp at Milrow and with kelp at Milrow. In addition to a base-case scenario that represents the best estimate of groundwater transport, there is a groundwater modeling sensitivity case that gives the result if there is reduced matrix diffusion. These nine groundwater scenarios are as follows:

- Combined source of Cannikin, Long Shot, and Milrow (no kelp); base-case groundwater model and sensitivity-case groundwater model

- Scenario 1: Fish subsistence diet for combined Cannikin, Long Shot, and Milrow (no kelp)

- Scenario 2: Marine mammal subsistence diet for combined Cannikin, Long Shot, and Milrow (no kelp)

- Scenario 3: Commercial catch diet for combined Cannikin, Long Shot, and Milrow (no kelp) 
- Combined source of Cannikin, Long Shot, and Milrow (with kelp); base-case groundwater model and sensitivity-case groundwater model

- Scenario 4: Fish subsistence diet for combined Cannikin, Long Shot, and Milrow (with kelp)

- Scenario 5: Marine mammal subsistence diet for combined Cannikin, Long Shot, and Milrow (with kelp)

- Scenario 6: Commercial catch diet for combined Cannikin, Long Shot, and Milrow (with kelp)

- Combined sources in Aleut culture and communication area; base-case groundwater model and sensitivity-case groundwater model

- Scenario 7: Fish subsistence diet for Aleut culture and communication area

- Scenario 8: Marine mammal subsistence diet for Aleut culture and communication area

- Scenario 9: Commercial catch diet for Aleut culture and communication area

To use these scenarios, an RRF was computed for each plume within each scenario. Risks for each were computed by multiplying each RRF by the modeled radionuclide fluxes. Risks for individual plumes were then summed to arrive at final cumulative risks in each scenario: (1) the sum of individual plumes, including Milrow (without kelp); (2) the sum of individual plumes, including Milrow (with kelp); and (3) the Aleut culture and communication area.

\subsection{Application of Calculational Process}

In the beginning of the site closure plan process, results come together from the groundwater model and the screening risk assessment (Figure 4). The results from the groundwater model are predicted locations and times of release of radionuclides. Other results of the groundwater model are possible fluxes of radionuclides entering marine water from areas of potential release on the ocean floor. Results of the screening risk assessment are modeled lifetime cancer risks from all radionuclides to human consumers eating marine food exposed to radionuclides potentially released from the Amchitka test sites.

The RRFs calculated by methods described in this report are used to calculate risks from fluxes predicted by the groundwater model. The risks from each radionuclide are summed to compute the annual risks, which are not classified because the nature and concentrations of individual 
radionuclides released by the blasts cannot be discerned when the risks from individual radionuclides are added together. These are the annual risks that are presented as lifetime risks by summing the annual risks for 70 years at a time.

The annual and lifetime risks are calculated for the modeled fluxes of 19 radionuclides through groundwater that would be expected from devices similar to the ones detonated at Amchitka. Calculations are made for 18 scenarios composed of various combinations of 2 groundwater flux models, 3 locations, and 3 dietary exposures. The groundwater flux model types, exposure locations, and dietary exposures are briefly described below.

Two different groundwater flux model scenarios are used to calculate the annual and lifetime risks: a base case and a sensitivity case. The base-case groundwater model represents the best estimate of groundwater model parameters. The sensitivity-case model represents radionuclide fluxes with reduced matrix diffusion, which means that some radionuclides are allowed to move rapidly and spread out less than the best estimates of parameters predict. Some aspects of the groundwater models are uncertain, due to data limitations and the natural spatial variability of the subsurface. This uncertainty is included in the groundwater models and is expressed as a standard deviation around the mean fluxes. The mean flux of the base-case model is the best estimate; by adding the standard deviation to the mean, a conservative estimate (meaning allowing higher fluxes) is obtained that accounts for uncertainty in our estimate of the mean. The same is done for the sensitivity case where the mean flux of this case can be compared to the base-case model to show the impact of matrix diffusion reduction, and by adding the standard deviation to this mean, the conservative estimate sensitivity to matrix diffusion is evaluated. It is important to realize that subtracting the standard deviation is equally valid for evaluating uncertainty as adding the standard deviation to the mean results. When the standard deviation is subtracted, no radionuclides from the tests reach the seafloor in any of the model calculations.

The estimated daily fluxes of radionuclides from the three tests are averaged for each of 1,000 years after the first test in 1965. The annual averages are multiplied by RRFs (Section 5.5) to obtain the annual risk for each radionuclide and for each test. All of the risks for a given year are then summed to obtain a single annual risk for each scenario.

Seventy-year cumulative risk values (lifetime risks to human health for developing cancer) are calculated by summing the annual risks for 70-year intervals, beginning with each successive year of 
model output. Thus, the value shown as the 70-year cumulative risk for the year 1965 is the risk for a lifetime exposure that began in 1965 and will end in 2034. This value is referred to hereafter as the "lifetime risk."

As shown above, three dilution scenarios are evaluated for calculating the annual and lifetime predicted risks: (1) Cannikin, Long Shot, and Milrow (no kelp); (2) Cannikin, Long Shot, and Milrow (with kelp); and (3) Aleut culture and communication area. The risk scenarios to human health from the 19 radionuclides are presented for both groundwater flux model scenarios and all 3 dilution scenarios.

The dietary exposure scenarios used to calculate the annual and lifetime risks include fish subsistence consumption, marine mammal subsistence consumption, and commercial catch consumption. The risks for each of the three dietary exposure scenarios are calculated for all three dilution scenarios for a total of nine risk scenarios. Predicted annual risks and predicted lifetime risks for all scenarios are presented in Section 5.8. The nine human health risk scenarios that are evaluated in this report were listed previously, showing their combinations of sources, groundwater flux model type, and dietary exposure scenarios.

Plots of the annual risk values for the mean radionuclide fluxes are prepared. These plots show the time elapsed since the first detonation (in years) on the $\mathrm{x}$-axis and the annual excess cancer risk on the $\mathrm{y}$-axis. However, the plots of annual risk values for mean radionuclide flux only show the narrower time frame between 0 and 100 years after detonations. The narrower range of years is chosen so the smaller scale enhances visualization of how the annual risk for mean radionuclide flux increased from 0 at time of the first detonation (1965) to the maximum risk value in relation to the present time (2002).

Plots of the lifetime risk values for the mean flux and the mean plus 2 standard deviations are prepared for each of the 18 risk scenarios. The plots show the time elapsed since the first detonation (in years) on the x-axis (0 to 1,000 years), and lifetime excess cancer risk on the y-axis (log scale). The lifetime excess cancer risk values are unitless probabilities that someone in the population will develop cancer during a 70-year lifetime as a result of lifelong exposure to radionuclides from the Amchitka devices. For example, a lifetime excess cancer risk value of $1.0 \times 10^{-5}$ represents a probability that 1 person out of 100,000 will develop cancer as a result of exposure to Amchitka radionuclides during a 70-year lifetime. This is also equivalent to saying that the probability of a 
given person developing cancer is $1.0 \times 10^{-5}$ more than the usual population frequency of cancer. The U.S. Environmental Protection Agency's (EPA's) “point of departure” for risk, $1.0 \times 10^{-6}$ (EPA, 1998) is also shown on the plots. This value represents EPA's lower limit of concern for carcinogens and the threshold below which EPA considers the risks to be undetectable. If the average lifetime risks are below $1.0 \times 10^{-6}$, EPA typically will not require further action. EPA's upper bound for average lifetime risk is $1.0 \times 10^{-4}(\mathrm{EPA}, 1998)$. The upper bound for average lifetime risk represents the threshold above which EPA considers the risks to be unacceptable and will likely require further action to reduce the risks to acceptable levels. Conditions that result in lifetime risks between $1.0 \times 10^{-6}$ and $1.0 \times 10^{-4}$ require further consideration of the need to reduce risks.

\section{$5.8 \quad$ Findings}

This section discusses the plots and written narratives of the predicted annual risk values for the mean radionuclide fluxes. In addition, the plots of the predicted lifetime risk values for the mean radionuclide flux and the mean plus 2 standard deviations that were prepared for each of the nine risk scenarios are discussed. The discussions focus on describing the predicted maximum lifetime risk values for the mean radionuclide flux and the mean plus 2 standard deviations for each of the nine scenarios and comparing those maximum values to EPA's point of departure for risk value of $1.0 \times 10^{-6}$. The discussions also indicate the years in which the predicted maximum lifetime risk values occur and their relation to the present year (2002).

In each scenario, results are first presented for the groundwater model base case, whose mean is the best estimate of risk. The base case is followed by the groundwater model sensitivity case, in which radionuclides are not retarded by their expected interaction with the subsurface.

\subsubsection{Scenario 1: Fish Subsistence Diet for Combined Source of Cannikin, Long Shot, and Milrow (No Kelp)}

\subsubsection{Base Case}

A plot of the modeled lifetime risk values for the mean radionuclide flux for the fish subsistence dietary exposure scenario for the combined source of Cannikin, Long Shot, and Milrow (no kelp), base-case groundwater model, along with the plot for the mean plus 2 standard deviations, is shown in Figure 5A for the entire modeled period. The maximum lifetime risk value for the mean radionuclide flux was $9.7 \times 10^{-11}$ lifetime excess cancer risk (Table 7), which is more than 
Table 7

Summary of Maximum Risk Values and the Calendar Year in Which Those Maximum Values Occur for Each of the 9 Risk Scenarios Based on Combinations of Groundwater Model Type, Dietary Exposure, and Location

(Page 1 of 2)

\begin{tabular}{|c|c|c|c|c|c|c|}
\hline \multirow[b]{2}{*}{$\begin{array}{l}\text { Groundwater Model Type, Dietary } \\
\text { Exposure, and Location Scenarios }\end{array}$} & \multicolumn{3}{|c|}{ Base-Case Groundwater Model Scenarios } & \multicolumn{3}{|c|}{ Sensitivity-Case Groundwater Model Scenarios } \\
\hline & $\begin{array}{c}\text { Maximum } \\
\text { Lifetime Risk } \\
\text { Values for } \\
\text { Mean } \\
\text { Radionuclide } \\
\text { Flux }\end{array}$ & $\begin{array}{l}\text { Maximum } \\
\text { Lifetime Risk } \\
\text { Values for Mean } \\
\text { Radionuclide } \\
\text { Flux + } 2 \text { S.D. }\end{array}$ & $\begin{array}{c}\text { Calendar Year } \\
\text { When Exposure } \\
\text { Began for } \\
\text { Maximum Lifetime } \\
\text { Risk for Mean } \\
\text { Radionuclide Flux }\end{array}$ & $\begin{array}{c}\text { Maximum } \\
\text { Lifetime Risk } \\
\text { Values for } \\
\text { Mean } \\
\text { Radionuclide } \\
\text { Flux }\end{array}$ & $\begin{array}{c}\text { Maximum } \\
\text { Lifetime Risk } \\
\text { Values for } \\
\text { Mean } \\
\text { Radionuclide } \\
\text { Flux }+2 \text { S.D. }\end{array}$ & $\begin{array}{c}\text { Calendar Year } \\
\text { When Exposure } \\
\text { Began for } \\
\text { Maximum Lifetime } \\
\text { Risk or Mean } \\
\text { Radionuclide Flux }\end{array}$ \\
\hline $\begin{array}{l}\text { Scenario 1: Fish subsistence diet exposure } \\
\text { at the combined Cannikin, Long Shot, and } \\
\text { Milrow (no kelp) location }\end{array}$ & $9.7 \mathrm{E}-11$ & $1.6 \mathrm{E}-09$ & 1994 & 1.7E-08 & $1.8 \mathrm{E}-07$ & 1968 \\
\hline $\begin{array}{l}\text { Scenario 2: Mammal subsistence diet } \\
\text { exposure at the combined Cannikin, Long } \\
\text { Shot, and Milrow (no kelp) location }\end{array}$ & $5.3 \mathrm{E}-11$ & $8.9 \mathrm{E}-10$ & 1990 & $9.7 \mathrm{E}-09$ & $9.4 \mathrm{E}-08$ & 1968 \\
\hline $\begin{array}{l}\text { Scenario 3: Commercial catch diet exposure } \\
\text { at the combined Cannikin, Long Shot, and } \\
\text { Milrow (no kelp) location }\end{array}$ & $4.2 \mathrm{E}-12$ & $7.0 \mathrm{E}-11$ & 1993 & $7.4 \mathrm{E}-10$ & 7.2E-09 & 1968 \\
\hline $\begin{array}{l}\text { Scenario 4: Fish subsistence diet exposure } \\
\text { at the combined Cannikin, Long Shot, and } \\
\text { Milrow (with kelp) location }\end{array}$ & $9.7 \mathrm{E}-11$ & $1.6 \mathrm{E}-09$ & 1994 & $1.9 \mathrm{E}-08$ & 2.3E-07 & 1968 \\
\hline $\begin{array}{l}\text { Scenario 5: Mammal subsistence diet } \\
\text { exposure at the combined Cannikin, Long } \\
\text { Shot, and Milrow (with kelp) location }\end{array}$ & 5.3E-11 & $8.9 \mathrm{E}-10$ & 1990 & $1.1 \mathrm{E}-08$ & $1.3 \mathrm{E}-07$ & 1968 \\
\hline $\begin{array}{l}\text { Scenario 6: Commercial catch diet exposure } \\
\text { at the combined Cannikin, Long Shot, and } \\
\text { Milrow (with kelp) location }\end{array}$ & 4.2E-12 & $7.0 \mathrm{E}-11$ & 1993 & $7.9 \mathrm{E}-10$ & 8.7E-09 & 1968 \\
\hline $\begin{array}{l}\text { Scenario 7: Fish subsistence diet exposure } \\
\text { at the Aleut culture and communication area } \\
\text { location }\end{array}$ & $2.1 \mathrm{E}-11$ & $3.4 \mathrm{E}-10$ & 1994 & 3.5E-09 & $3.5 \mathrm{E}-08$ & 1968 \\
\hline
\end{tabular}


Table 7

Summary of Maximum Risk Values and the Calendar Year in Which Those Maximum Values Occur for Each of the 9 Risk Scenarios Based on Combinations of Groundwater Model Type, Dietary Exposure, and Location

(Page 2 of 2)

\begin{tabular}{|c|c|c|c|c|c|c|}
\hline \multirow[b]{2}{*}{$\begin{array}{l}\text { Groundwater Model Type, Dietary } \\
\text { Exposure, and Location Scenarios }\end{array}$} & \multicolumn{3}{|c|}{ Base-Case Groundwater Model Scenarios } & \multicolumn{3}{|c|}{ Sensitivity-Case Groundwater Model Scenarios } \\
\hline & $\begin{array}{l}\text { Maximum } \\
\text { Lifetime Risk } \\
\text { Values for } \\
\text { Mean } \\
\text { Radionuclide } \\
\text { Flux }\end{array}$ & $\begin{array}{l}\text { Maximum } \\
\text { Lifetime Risk } \\
\text { Values for Mean } \\
\text { Radionuclide } \\
\text { Flux + } 2 \text { S.D. }\end{array}$ & $\begin{array}{c}\text { Calendar Year } \\
\text { When Exposure } \\
\text { Began for } \\
\text { Maximum Lifetime } \\
\text { Risk for Mean } \\
\text { Radionuclide Flux }\end{array}$ & $\begin{array}{c}\text { Maximum } \\
\text { Lifetime Risk } \\
\text { Values for } \\
\text { Mean } \\
\text { Radionuclide } \\
\text { Flux }\end{array}$ & $\begin{array}{c}\text { Maximum } \\
\text { Lifetime Risk } \\
\text { Values for } \\
\text { Mean } \\
\text { Radionuclide } \\
\text { Flux + } 2 \text { S.D. }\end{array}$ & $\begin{array}{c}\text { Calendar Year } \\
\text { When Exposure } \\
\text { Began for } \\
\text { Maximum Lifetime } \\
\text { Risk or Mean } \\
\text { Radionuclide Flux }\end{array}$ \\
\hline $\begin{array}{l}\text { Scenario 8: Mammal subsistence diet } \\
\text { exposure at the Aleut culture and } \\
\text { communication area location }\end{array}$ & $1.1 \mathrm{E}-11$ & $1.9 \mathrm{E}-10$ & 1990 & $2.0 \mathrm{E}-09$ & $1.9 \mathrm{E}-08$ & 1968 \\
\hline $\begin{array}{l}\text { Scenario 9: Commercial catch diet exposure } \\
\text { at the Aleut culture and communication area } \\
\text { location }\end{array}$ & $8.9 E-13$ & $1.5 \mathrm{E}-11$ & 1993 & $1.5 \mathrm{E}-10$ & $1.4 \mathrm{E}-09$ & 1968 \\
\hline
\end{tabular}

a $\quad$ S.D. = Standard deviations 
10,000-fold lower than EPA's point of departure for risk of $1.0 \times 10^{-6}$. The maximum lifetime risk value for the mean radionuclide flux plus 2 standard deviations was $1.6 \times 10^{-9}$ (Table 7), which is more than 500-fold lower than the EPA's point of departure for risk.

The maximum modeled lifetime risk for the mean radionuclide flux was for a 70-year lifetime of exposure that began in 1994. Lifetime risks are predicted to have decreased for exposures that have begun since that year to the current value of $9.6 \times 10^{-11}$, and will continue to decrease in the future (Figure 5A).

\subsubsection{Groundwater Modeling Sensitivity Case}

A plot of the modeled lifetime risk values for the mean radionuclide flux for the fish subsistence dietary exposure scenario for the combined source of Cannikin, Long Shot, and Milrow (no kelp), sensitivity-case groundwater model, along with the plot for the mean plus 2 standard deviations, is shown in Figure 5B for the entire modeled period. The maximum lifetime risk value for the mean radionuclide flux was $1.7 \times 10^{-8}$ lifetime excess cancer risk (Table 7), which is more than 50-fold lower than EPA's point of departure for risk of $1.0 \times 10^{-6}$. The maximum lifetime risk value for the mean radionuclide flux plus 2 standard deviations was $1.8 \times 10^{-7}$ (Table 7), which is more than 5-fold lower than the EPA's point of departure for risk.

The maximum modeled lifetime risk for the mean radionuclide flux was for exposure that began in 1968. Lifetime risks are predicted to have decreased for exposures that have begun since that year to the current value of $8.4 \times 10^{-9}$, and will continue to decrease in the future (Figure 5B).

\subsubsection{Conclusion}

All of the modeled lifetime risk values for the mean radionuclide flux (as well as the mean plus 2 standard deviation values) during the entire 1,000-year period evaluated for this dietary exposure, location, and base-case and sensitivity-case models are below EPA's point of departure for risk. 


\subsubsection{Scenario 2: Marine Mammal Subsistence Diet for Combined Source of Cannikin, Long Shot, and Milrow (No Kelp)}

\subsubsection{Base Case}

A plot of the modeled lifetime risk values for the mean radionuclide flux for the marine mammal subsistence dietary exposure scenario for the combined source of Cannikin, Long Shot, and Milrow (no kelp), base-case groundwater model, along with the plot for the mean plus 2 standard deviations, is shown in Figure 6A for the entire modeled period. The maximum lifetime risk value for the mean radionuclide flux was $5.3 \times 10^{-11}$ lifetime excess cancer risk (Table 7), which is more than 10,000-fold lower than EPA's point of departure for risk of $1.0 \times 10^{-6}$. The maximum lifetime risk value for the mean radionuclide flux plus 2 standard deviations was $8.9 \times 10^{-10}$ (Table 7), which is more than 1,000-fold lower than the EPA's point of departure for risk.

The maximum modeled lifetime risk for the mean radionuclide flux was for exposure that began in 1990. Lifetime risks are predicted to have decreased for exposures that have begun since that year to the current value of $5.0 \times 10^{-11}$, and will continue to decrease in the future (Figure 6A).

\subsubsection{Groundwater Modeling Sensitivity Case}

A plot of the modeled lifetime risk values for the mean radionuclide flux for the marine mammal subsistence dietary exposure scenario for the combined source of Cannikin, Long Shot, and Milrow (no kelp), sensitivity-case groundwater model, along with the plot for the mean plus 2 standard deviations, is shown in Figure 6B for the entire modeled period. The maximum lifetime risk value for the mean radionuclide flux was $9.7 \times 10^{-9}$ lifetime excess cancer risk (Table 7), which is more than 100 -fold lower than EPA's point of departure for risk of $1.0 \times 10^{-6}$. The maximum lifetime risk value for the mean radionuclide flux plus 2 standard deviations was $9.4 \times 10^{-8}$ (Table 7), which is more than 10-fold lower than the EPA point of departure for risk.

The maximum modeled lifetime risk for the mean radionuclide flux was for exposure that began in 1968. Lifetime risks are predicted to have decreased for exposures that have begun since that year to the current value of $3.8 \times 10^{-9}$, and will continue to decrease in the future (Figure 6B). 


\subsubsection{Conclusion}

All of the modeled lifetime risk values for the mean radionuclide flux (as well as the mean plus 2 standard deviation values) during the entire 1,000-year period evaluated for this dietary exposure, location, and base-case model and sensitivity-case models are far below EPA's point of departure for risk.

\subsubsection{Scenario 3: Commercial Catch Diet for Combined Source of Cannikin, Long Shot, and Milrow (No Kelp)}

\subsubsection{Base Case}

A plot of the modeled lifetime risk values for the mean radionuclide flux for the commercial catch dietary exposure scenario for the combined source of Cannikin, Long Shot, and Milrow (no kelp), base-case groundwater model, along with the plot for the mean plus 2 standard deviations, is shown in Figure 7A for the entire modeled period. The maximum lifetime risk value for the mean radionuclide flux was $4.2 \times 10^{-12}$ lifetime excess cancer risk (Table 7), which is more than 200,000-fold lower than EPA's point of departure for risk of $1.0 \times 10^{-6}$. The maximum lifetime risk value for the mean radionuclide flux plus 2 standard deviations was $7.0 \times 10^{-11}$ (Table 7), which is more than 10,000-fold lower than the EPA's point of departure for risk.

The maximum modeled lifetime risk for the mean radionuclide flux was for exposure that began in 1993. Lifetime risks are predicted to have decreased for exposures that have begun since that year to the current value of $4.1 \times 10^{-12}$, and will continue to decrease in the future (Figure 7A).

\subsubsection{Groundwater Modeling Sensitivity Case}

A plot of the modeled lifetime risk values for the mean radionuclide flux for the commercial catch dietary exposure scenario for the combined source of Cannikin, Long Shot, and Milrow (no kelp), sensitivity-case groundwater model, along with the plot for the mean plus 2 standard deviations, is shown in Figure 7B for the entire modeled period. The maximum lifetime risk value for the mean radionuclide flux was $7.4 \times 10^{-10}$ lifetime excess cancer risk (Table 7), which is more than 1,000-fold lower than EPA's point of departure for risk of $1.0 \times 10^{-6}$. The maximum lifetime risk value for the mean radionuclide flux plus 2 standard deviations was $7.2 \times 10^{-9}$ (Table 7), which is more than 100 -fold lower than the EPA's point of departure for risk. 
The maximum modeled lifetime risk for the mean radionuclide flux was for exposure that began in 1968. Lifetime risks are predicted to have decreased for exposures that have begun since that year to the current value of $3.4 \times 10^{-10}$, and will continue to decrease in the future (Figure 7B).

\subsubsection{Conclusion}

All of the modeled lifetime risk values for the mean radionuclide flux (as well as the mean plus 2 standard deviation values) during the entire 1,000-year period evaluated for this dietary exposure, location, and base-case model and sensitivity-case models are far below EPA's point of departure for risk.

\subsubsection{Scenario 4: Fish Subsistence Diet for Combined Source of Cannikin, Long Shot, and Milrow (With Kelp)}

\subsubsection{Base Case}

A plot of the modeled lifetime risk values for the mean radionuclide flux for the fish subsistence dietary exposure scenario for the combined source of Cannikin, Long Shot, and Milrow (with kelp), base-case groundwater model, along with the plot for the mean plus 2 standard deviations, is shown in Figure 8A for the entire modeled period. The maximum lifetime risk value for the mean radionuclide flux was $9.7 \times 10^{-11}$ lifetime excess cancer risk (Table 7), which is more than 10,000-fold lower than EPA's point of departure for risk of $1.0 \times 10^{-6}$. The maximum lifetime risk value for the mean radionuclide flux plus 2 standard deviations was $1.6 \times 10^{-9}$ (Table 7), which is more than 500-fold lower than the EPA's point of departure for risk.

The maximum modeled lifetime risk for the mean radionuclide flux was for exposure that began in 1994. Lifetime risks are predicted to have decreased for exposures that have begun since that year to the current value of $9.6 \times 10^{-11}$, and will continue to decrease in the future (Figure 8A).

\subsubsection{Groundwater Modeling Sensitivity Case}

A plot of the modeled lifetime risk values for the mean radionuclide flux for the fish subsistence dietary exposure scenario for the combined source of Cannikin, Long Shot, and Milrow (with kelp), sensitivity-case groundwater model, along with the plot for the mean plus 2 standard deviations, is shown in Figure $8 \mathrm{~B}$ for the entire modeled period. The maximum lifetime risk value for the mean 
radionuclide flux was $1.9 \times 10^{-8}$ lifetime excess cancer risk (Table 7), which is more than 50-fold lower than EPA's point of departure for risk of $1.0 \times 10^{-6}$. The maximum lifetime risk value for the mean radionuclide flux plus 2 standard deviations was $2.3 \times 10^{-7}$ (Table 7), which is more than 5-fold lower than the EPA's point of departure for risk.

The maximum modeled lifetime risk for the mean radionuclide flux was for exposure that began in 1968. Lifetime risks are predicted to have decreased for exposures that have begun since that year to the current value of $9.2 \times 10^{-9}$, and will continue to decrease in the future (Figure 8B).

\subsubsection{Conclusion}

All of the modeled lifetime risk values for the mean radionuclide flux (as well as the means plus 2 standard deviation values) during the entire 1,000 year period evaluated for this dietary exposure location, and base-case model and sensitivity case models are below EPA's point of departure for risk.

\subsubsection{Scenario 5: Marine Mammal Subsistence Diet for Combined Source of Cannikin, Long Shot, and Milrow (With Kelp)}

\subsubsection{Base Case}

A plot of the modeled lifetime risk values for the mean radionuclide flux for the marine mammal subsistence dietary exposure scenario for the combined source of Cannikin, Long Shot, and Milrow (with kelp), base-case groundwater model, along with the plot for the mean plus 2 standard deviations, is shown in Figure 9A for the entire modeled period. The maximum lifetime risk value for the mean radionuclide flux was $5.3 \times 10^{-11}$ lifetime excess cancer risk (Table 7), which is nearly 20,000-fold lower than EPA's point of departure for risk of $1.0 \times 10^{-6}$. The maximum lifetime risk value for the mean radionuclide flux plus 2 standard deviations was $8.9 \times 10^{-10}$ (Table 7), which is more than 1,000-fold lower than the EPA's point of departure for risk.

The maximum modeled lifetime risk for the mean radionuclide flux was for exposure that began in 1990. Lifetime risks are predicted to have decreased for exposures that have begun since that year to the current value of $5.0 \times 10^{-11}$, and will continue to decrease in the future (Figure 9A). 


\subsubsection{Groundwater Modeling Sensitivity Case}

A plot of the modeled lifetime risk values for the mean radionuclide flux for the marine mammal subsistence dietary exposure for the combined source of Cannikin, Long Shot, and Milrow (with kelp), sensitivity-case groundwater model scenario, along with the plot for the mean plus 2 standard deviations, is shown in Figure 9B for the entire modeled period. The maximum lifetime risk value for the mean radionuclide flux was $1.1 \times 10^{-8}$ lifetime excess cancer risk (Table 7), which is nearly 100 -fold lower than EPA's point of departure for risk of $1.0 \times 10^{-6}$. The maximum lifetime risk value for the mean radionuclide flux plus 2 standard deviations was $1.3 \times 10^{-7}$ (Table 7), which is nearly 8 -fold lower than the EPA's point of departure for risk.

The maximum modeled lifetime risk for the mean radionuclide flux was for exposure that began in 1968. Lifetime risks are predicted to have decreased for exposures that have begun since that year to the current value of $4.3 \times 10^{-9}$, and will continue to decrease in the future (Figure 9B).

\subsubsection{Conclusion}

All of the modeled lifetime risk values for the mean radionuclide flux (as well as the mean plus 2 standard deviation values) during the entire 1,000-year period evaluated for this dietary exposure, location, and base-case model and sensitivity-case models are far below EPA's point of departure for risk.

\subsubsection{Scenario 6: Commercial Catch Diet for Combined Source of Cannikin, Long Shot, and Milrow (With Kelp)}

\subsubsection{Base Case}

A plot of the modeled lifetime risk values for the mean radionuclide flux for the commercial catch dietary exposure scenario for the combined source of Cannikin, Long Shot, and Milrow (with kelp), base-case groundwater model, along with the plot for the mean plus 2 standard deviations, is shown in Figure 10A for the entire modeled period. The maximum lifetime risk value for the mean radionuclide flux was $4.2 \times 10^{-12}$ lifetime excess cancer risk (Table 7), which is more than 200,000-fold lower than EPA's point of departure for risk of $1.0 \times 10^{-6}$. The maximum lifetime risk value for the mean radionuclide flux plus 2 standard deviations was $7.0 \times 10^{-11}$ (Table 7), which is more than 10,000-fold lower than the EPA's point of departure for risk. 
The maximum modeled lifetime risk for the mean radionuclide flux was for exposure that began in 1993. Lifetime risks are predicted to have decreased for exposures that have begun since that year to the current value of $4.1 \times 10^{-12}$, and will continue to decrease in the future (Figure 10A).

\subsubsection{Groundwater Modeling Sensitivity Case}

A plot of the modeled lifetime risk values for the mean radionuclide flux for the commercial catch dietary exposure scenario for the combined source of Cannikin, Long Shot, and Milrow (with kelp), sensitivity-case groundwater model, along with the plot for the mean plus 2 standard deviations, is shown in Figure 10B for the entire modeled period. The maximum lifetime risk value for the mean radionuclide flux was $7.9 \times 10^{-10}$ lifetime excess cancer risk (Table 7), which is more than 1,000-fold lower than EPA's point of departure for risk of $1.0 \times 10^{-6}$. The maximum lifetime risk value for the mean radionuclide flux plus 2 standard deviations was $8.7 \times 10^{-9}$ (Table 7), which is more than 100 -fold lower than the EPA's point of departure for risk.

The maximum modeled lifetime risk for the mean radionuclide flux was for exposure that began in 1968. Lifetime risks are predicted to have decreased for exposures that have begun since that year to the current value of $3.7 \times 10^{-10}$, and will continue to decrease in the future (Figure 10B).

\subsubsection{Conclusion}

All of the modeled lifetime risk values for the mean radionuclide flux (as well as the mean plus 2 standard deviation values) during the entire 1,000-year period evaluated for this dietary exposure, location, and base-case model and sensitivity-case models are far below EPA's point of departure for risk.

\subsubsection{Scenario 7: Fish Subsistence Diet for Combined Sources in the Aleut Culture and Communication Area}

\subsubsection{Base Case}

A plot of the modeled lifetime risk values for the mean radionuclide flux for the fish subsistence dietary exposure scenario for the combined sources of Cannikin, Long Shot, and Milrow, base-case groundwater model in the Aleut culture and communication area, along with the plot for the mean plus 2 standard deviations, is shown in Figure 11A for the entire modeled period. The maximum 
lifetime risk value for the mean radionuclide flux was $2.1 \times 10^{-11}$ lifetime excess cancer risk (Table 7), which is nearly 50,000-fold lower than EPA's point of departure for risk of $1.0 \times 10^{-6}$. The maximum lifetime risk value for the mean radionuclide flux plus 2 standard deviations was $3.4 \times 10^{-10}$ (Table 7), which is nearly 3,000-fold lower than the EPA's point of departure for risk.

The maximum modeled lifetime risk for the mean radionuclide flux was for exposure that began in 1994. Lifetime risks are predicted to have decreased for exposures that have begun since that year to the current value of $2.0 \times 10^{-11}$, and will continue to decrease in the future (Figure 11A).

\subsubsection{Groundwater Modeling Sensitivity Case}

A plot of the modeled lifetime risk values for the mean radionuclide flux for the fish subsistence dietary exposure scenario for the combined source in the Aleut culture and communication area, sensitivity-case groundwater model, along with the plot for the mean plus 2 standard deviations, is shown in Figure 11B for the entire modeled period. The maximum lifetime risk value for the mean radionuclide flux was $3.5 \times 10^{-9}$ lifetime excess cancer risk (Table 7), which is nearly 300 -fold lower than EPA's point of departure for risk of $1.0 \times 10^{-6}$. The maximum lifetime risk value for the mean radionuclide flux plus 2 standard deviations was $3.5 \times 10^{-8}$ (Table 7), which is nearly 30 -fold lower than the EPA's point of departure for risk.

The maximum modeled lifetime risk for the mean radionuclide flux was for exposure that began in 1968. Lifetime risks are predicted to have decreased for exposures that have begun since that year to the current value of $1.6 \times 10^{-9}$, and will continue to decrease in the future (Figure 11B).

\subsubsection{Conclusion}

All of the modeled lifetime risk values for the mean radionuclide flux (as well as the mean plus 2 standard deviation values) during the entire 1,000-year period evaluated for this dietary exposure, location, and base-case model and sensitivity-case models are far below EPA's point of departure for risk. 


\subsubsection{Scenario 8: Marine Mammal Subsistence Diet for Combined Sources in the Aleut Culture and Communication Area}

\subsubsection{Base Case}

A plot of the modeled lifetime risk values for the mean radionuclide flux for the marine mammal subsistence dietary exposure scenario for the combined sources of Cannikin, Long Shot, and Milrow, base-case groundwater model in the Aleut culture and communication area, along with the plot for the mean plus 2 standard deviations, is shown in Figure 12A for the entire modeled period. The maximum lifetime risk value for the mean radionuclide flux was $1.1 \times 10^{-11}$ lifetime excess cancer risk (Table 7), which is nearly 100,000-fold lower than EPA's point of departure for risk of $1.0 \times 10^{-6}$. The maximum lifetime risk value for the mean radionuclide flux plus 2 standard deviations was $1.9 \times 10^{-10}$ (Table 7), which is more than 5,000-fold lower than the EPA's point of departure for risk.

The maximum modeled lifetime risk for the mean radionuclide flux was for exposure that began in 1990. Lifetime risks are predicted to have decreased for exposures that have begun since that year to the current value of $1.07 \times 10^{-11}$, and will continue to decrease in the future (Figure 12A).

\subsubsection{Groundwater Modeling Sensitivity Case}

A plot of the modeled lifetime risk values for the mean radionuclide flux for the marine mammal subsistence dietary exposure scenario for the combined sources in the Aleut culture and communication area, along with the plot for the mean plus 2 standard deviations, is shown in Figure 11B for the entire modeled period. The maximum lifetime risk value for the mean radionuclide flux was $2.0 \times 10^{-9}$ lifetime excess cancer risk (Table 7), which is 500-fold lower than EPA's point of departure for risk of $1.0 \times 10^{-6}$. The maximum lifetime risk value for the mean radionuclide flux plus 2 standard deviations was $1.9 \times 10^{-8}$ (Table 7), which is more than 50-fold lower than the EPA's point of departure for risk.

The maximum modeled lifetime risk for the mean radionuclide flux was for exposure that began in 1968. Lifetime risks are predicted to have decreased for exposures that have begun since that year to the current value of $7.7 \times 10^{-10}$, and will continue to decrease in the future (Figure 11B). 


\subsubsection{Conclusion}

All of the modeled lifetime risk values for the mean radionuclide flux (as well as the mean plus 2 standard deviation values) during the entire 1,000-year period evaluated for this dietary exposure, location, and base-case model and sensitivity-case models are far below EPA's point of departure for risk.

\subsubsection{Scenario 9: Commercial Catch Diet for Combined Sources in the Aleut Culture and Communication Area}

\subsubsection{Base Case}

A plot of the modeled lifetime risk values for the mean radionuclide flux for the commercial catch dietary exposure scenario for the combined sources of Cannikin, Long Shot, and Milrow, base-case groundwater model in the Aleut culture and communication area, along with the plot for the mean plus 2 standard deviations, is shown in Figure 13A for the entire modeled period. The maximum lifetime risk value for the mean radionuclide flux was $8.9 \times 10^{-13}$ lifetime excess cancer risk (Table 7), which is more than 1,000,000-fold lower than EPA's point of departure for risk of $1.0 \times 10^{-6}$. The maximum lifetime risk value for the mean radionuclide flux plus 2 standard deviations was $1.5 \times 10^{-11}$ (Table 7), which is more than 60,000 -fold lower than the EPA's point of departure for risk.

The maximum modeled lifetime risk for the mean radionuclide flux was for exposure that began in 1993. Lifetime risks are predicted to have decreased for exposures that have begun since that year to the current value of $8.7 \times 10^{-13}$, and will continue to decrease in the future (Figure 13A).

\subsubsection{Groundwater Modeling Sensitivity Case}

A plot of the modeled lifetime risk values for the mean radionuclide flux for the commercial catch dietary exposure scenario for the combined sources in the Aleut culture and communication area, sensitivity-case groundwater model, along with the plot for the mean plus 2 standard deviations, is shown in Figure 13B for the entire modeled period. The maximum lifetime risk value for the mean radionuclide flux was $1.5 \times 10^{-10}$ lifetime excess cancer risk (Table 7), which is more than 6,000-fold lower than EPA's point of departure for risk of $1.0 \times 10^{-6}$. The maximum lifetime risk value for the 
mean radionuclide flux plus 2 standard deviations was $1.4 \times 10^{-9}$ (Table 7), which is more than 700-fold lower than the EPA's point of departure for risk.

The maximum modeled lifetime risk for the mean radionuclide flux was for exposure that began in 1968. Lifetime risks are predicted to have decreased for exposures that have begun since that year to the current value of $6.6 \times 10^{-11}$, and will continue to decrease in the future (Figure 13B).

\subsubsection{Conclusion}

All of the modeled lifetime risk values for the mean radionuclide flux (as well as the mean plus 2 standard deviation values) during the entire 1,000-year period evaluated for this dietary exposure, location, and base-case model and sensitivity-case models are far below EPA's point of departure for risk. 
Table 8

Maximum Lifetime Risk Values for the Mean Radionuclide Flux

Lifetime Excess Cancer Risks for Each of the 9 Risk Scenarios,

Ranked from Highest to Lowest

\begin{tabular}{|c|c|c|c|c|c|c|}
\hline \multirow[b]{2}{*}{ Rank } & \multirow[b]{2}{*}{$\begin{array}{l}\text { Scenario } \\
\text { Number }\end{array}$} & \multirow[b]{2}{*}{$\begin{array}{l}\text { Dietary Exposure, Location } \\
\text { Groundwater Model Type Combination }\end{array}$} & \multicolumn{2}{|c|}{$\begin{array}{l}\text { Base-Case Groundwater Model } \\
\text { Scenarios }\end{array}$} & \multicolumn{2}{|c|}{$\begin{array}{l}\text { Sensitivity-Case Groundwater } \\
\text { Model Scenarios }\end{array}$} \\
\hline & & & $\begin{array}{c}\text { Maximum } \\
\text { Lifetime Risk } \\
\text { Values for } \\
\text { Mean } \\
\text { Radionuclide } \\
\text { Flux }\end{array}$ & $\begin{array}{l}\text { Maximum } \\
\text { Lifetime Risk } \\
\text { Values for Mean } \\
\text { Radionuclide } \\
\text { Flux + } 2 \text { S.D. }\end{array}$ & $\begin{array}{c}\text { Maximum } \\
\text { Lifetime Risk } \\
\text { Values for } \\
\text { Mean } \\
\text { Radionuclide } \\
\text { Flux }\end{array}$ & $\begin{array}{c}\text { Maximum } \\
\text { Lifetime Risk } \\
\text { Values for } \\
\text { Mean } \\
\text { Radionuclide } \\
\text { Flux + 2 S.D. }\end{array}$ \\
\hline 1 & 4 & $\begin{array}{l}\text { Fish subsistence diet exposure for combined Cannikin, } \\
\text { Long Shot, and Milrow (with kelp) }\end{array}$ & $9.7 \times 10^{-11}$ & $1.6 \times 10^{-9}$ & $1.9 \times 10^{-8}$ & $2.3 \times 10^{-7}$ \\
\hline 2 & 1 & $\begin{array}{l}\text { Fish subsistence diet for combined Cannikin, Long Shot, } \\
\text { and Milrow (with no kelp) }\end{array}$ & $9.7 \times 10^{-11}$ & $1.6 \times 10^{-9}$ & $1.7 \times 10^{-8}$ & $1.8 \times 10^{-7}$ \\
\hline 3 & 5 & $\begin{array}{l}\text { Marine mammal subsistence diet for combined Cannikin, } \\
\text { Long Shot, and Milrow (with kelp) }\end{array}$ & $5.3 \times 10^{-11}$ & $8.9 \times 10^{-10}$ & $1.1 \times 10^{-8}$ & $1.3 \times 10^{-7}$ \\
\hline 4 & 2 & $\begin{array}{l}\text { Marine mammal subsistence diet for combined Cannikin, } \\
\text { Long Shot, and Milrow (with no kelp) }\end{array}$ & $5.3 \times 10^{-11}$ & $8.9 \times 10^{-10}$ & $9.7 \times 10^{-9}$ & $9.4 \times 10^{-8}$ \\
\hline 5 & 7 & $\begin{array}{l}\text { Fish subsistence diet for Aleut culture and } \\
\text { communication area }\end{array}$ & $2.1 \times 10^{-11}$ & $3.4 \times 10^{-10}$ & $3.5 \times 10^{-9}$ & $3.5 \times 10^{-8}$ \\
\hline 6 & 8 & $\begin{array}{l}\text { Marine mammal subsistence diet for Aleut culture and } \\
\text { communication area }\end{array}$ & $1.1 \times 10^{-11}$ & $1.9 \times 10^{-10}$ & $2.0 \times 10^{-9}$ & $1.9 \times 10^{-8}$ \\
\hline 7 & 6 & $\begin{array}{l}\text { Commercial catch for combined Cannikin, Long Shot, } \\
\text { and Milrow (with kelp) }\end{array}$ & $4.2 \times 10^{-12}$ & $7.0 \times 10^{-11}$ & $7.9 \times 10^{-10}$ & $8.7 \times 10^{-9}$ \\
\hline 8 & 3 & $\begin{array}{l}\text { Commercial catch for combined Cannikin, Long Shot, } \\
\text { and Milrow (with no kelp) }\end{array}$ & $4.2 \times 10^{-12}$ & $7.0 \times 10^{-11}$ & $7.4 \times 10^{-10}$ & $7.2 \times 10^{-9}$ \\
\hline 9 & 9 & Commercial catch for culture and communications area & $8.9 \times 10^{-13}$ & $1.5 \times 10^{-11}$ & $1.5 \times 10^{-10}$ & $1.4 \times 10^{-9}$ \\
\hline
\end{tabular}




\subsection{Data Quality and Uncertainty}

These results were calculated by using the best available knowledge about the Amchitka marine environment assembled and synthesized from many sources. For example, the best estimate of potential groundwater flux at the ocean floor is the mean or average of the results of groundwater modeling with peer-reviewed models. Modeling the dispersion of radionuclides in seawater used an EPA-approved model (CORMIX). In turn, this model used the best available data from Amchitka on current velocity, salinity gradients, and other inputs.

Whenever precise data were lacking or if there was uncertainty about parameters, values were conservatively chosen from the available data to calculate higher potential exposures rather than lower exposures. For example, subsistence fishers (Sections A.7 and A.8) were modeled as eating more fish than reported by Aleut communities, all people in all non-Aleut populations were assumed to eat fish from the Bering Sea and northern Pacific Ocean at conservative consumption rates (Section A.8.0), and marine fish and mammals were modeled in food chains (Section A.9.0 and Section A.10.0) as having higher uptake factors from seawater and food than is likely in a real setting. Subsistence consumers (Section A.8.0) were modeled as eating a quantity of food per day that is an upper bound of reported ingestion rates. Subsistence fishers (Section A.10.0) were assumed to fish in an area where they could harvest contaminated fish for a longer period of the time than is likely. Further, the screening level of $1 \times 10^{-6}$ or one excess cancer case in a million people (Section A.12.0) is considered by the EPA to be below the level of concern. Thus, conservative values were used in the absence of precise data.

Although the best estimates of parameter values were used, some could be above or below the actual numerical values. For nearshore exposure (Section A.6.2.2), the groundwater fluxes are mean values and could be higher or lower (CORMIX model input parameter values are based on measured conditions near Amchitka, and the dilution factor for each plume is based on best scientific judgment and could be higher or lower). The dilution factor for offshore exposure (Section A.6.2.3) is based on a published dilution model, but it also has some uncertainty. Cancer morbidity risk coefficients (Section A.11.0) are central tendency values that EPA states have some uncertainty, and the actual coefficient could be higher or lower. In such situations, a conservative value was used as appropriate in a screening risk assessment. 
Uncertainties also exist in the groundwater flow and transport modeling that feeds into the risk assessment. The same technical approach was used in that effort whereby parameter values were chosen to allow more rapid transport than slower, if precise data were lacking. For example, although limited data with significant uncertainties indicate the fracture porosity at Amchitka is on the order of $1 \times 10^{-3}$, a value of $5 \times 10^{-4}$ (resulting in faster groundwater velocities) was used for the mean porosity in the modeling in order to be conservative. A parametric uncertainty analysis was performed for the groundwater modeling and those parameters whose uncertainty significantly impacted the radionuclide breakthrough were included as uncertainties in the final modeling. This allows the consequences of uncertainty to be quantified for the groundwater model, expressed as a standard deviation of the breakthrough curves. Including the standard deviation in the risk calculations allows the groundwater model uncertainty to be carried into the risk assessment. The mean plus two standard deviations presented in this report is a highly conservative expression of the uncertainty coming from the groundwater model. The mean minus two standard deviations (and the mean minus one standard deviation as well) is equally valid and shows no release of radionuclides from any of the tests to the seafloor in 1,000 years.

Uncertainty about the selection of radionuclides of potential concern (Section A.2.0) and calculation of risk using output of other sections (Section A.14.0) is expected to have little effect on the results because there is little uncertainty about these elements. Uncertainty about the locations of releases (Section A.3.0), seabed substrates (Section A.4.0), transport by currents (Section A.5.0), and biomass density of fish (Section A.10.0), have a minor mathematical influence on the results.

In summary, the screening risk assessment used conservative data and conservative assumptions, and the results show potential risk levels to be well below the most conservative EPA risk thresholds for both subsistence users and commercial catch consumers. Because many of the parameter values were chosen to be very conservative, the results may overstate the risks by more than two orders of magnitude. 


\subsection{Summary}

1. The most significant finding is that risks to human health from all the dietary exposure scenarios and locations from the sum of 19 selected radionuclides potentially released from the detonations are calculated to be well below EPA's lower limit of concern and so low that EPA considers them to be undetectable. The calculated lifetime excess cancer risks for the best estimate of groundwater flow and transport range from $8.9 \times 10^{-13}$ to $9.7 \times 10^{-11}$. This is 10,000 to $1,000,000$ fold lower than EPA's point of departure for a risk value of $1 \times 10^{-6}$.

2. Uncertainty in the estimate of groundwater flow and transport is expressed as a standard deviation for the mean flux. Considering two standard deviations added to the mean allows a highly conservative expression of uncertainty. The calculated lifetime excess cancer risks for the mean plus two standard deviations of radionuclide flux ranges from $1.5 \times 10^{-11}$ to $1.6 \times 10^{-9}$. If the upper bound of uncertainty is considered, the lower bound must be as well. Two standard deviations subtracted from the mean mathematically yields no radionuclide flux to the environment and no excess cancer risk. Therefore, a highly conservative range of groundwater flux values yields risks ranging from no excess risk to 600-fold below EPA's point of departure.

3. A sensitivity analysis was also performed with the groundwater model, allowing more rapid transport by reducing matrix diffusion below the best estimate. The calculated lifetime excess cancer risk for the sensitivity case ranged from $1.5 \times 10^{-10}$ to $1.9 \times 10^{-8}$ for the mean, $1.4 \times 10^{-9}$ to $2.3 \times 10^{-7}$ for the mean plus two standard deviations, and no excess risk for the mean minus two standard deviations. Thus, even incorporating significant conservatism into the calculation of radionuclide flux through groundwater, the risk is still well below EPA's lower limit of concern.

4. Conservative values for risk assessment model parameters were chosen from the best available knowledge. The degree of conservatism in the choice of parameters for dispersion modeling, definitions of the exposed populations, percent of diet coming from the vicinity of Amchitka, amount of fish and marine mammals consumed in the diet, and bioconcentration factors for radionuclides contributed to an overestimate of risk by an estimated two orders of magnitude or more.

5. The predicted lifetime risk values for the nine scenarios for the mean radionuclide flux are ranked from highest to lowest in Table 8, with the highest mean flux value $9.7 \times 10^{-11}$. This value is for the scenario of fish subsistence dietary exposure at the combined Cannikin, Long Shot, and Milrow location (with or without kelp), groundwater model base case.

6. The maximum lifetime risk value of $9.7 \times 10^{-11}$ occurred for exposure beginning in 1968 , three years after the first detonation in October 1965. Risks have decreased since that time and are predicted to continue to decrease through the year 2965 and beyond the modeled period. 
7. The lowest of the maximum lifetime risk values for the mean radionuclide flux, $8.9 \times 10^{-13}$, was for the commercial catch dietary exposure, Aleut culture and communication area location, base-case groundwater model scenario.

8. For all nine risk scenarios that were evaluated, the lifetime risk values for the mean radionuclide flux for the sensitivity-case groundwater model were approximately 100-fold greater than lifetime risk values for the mean radionuclide flux for the base-case groundwater model.

In summary, the most important result of the Amchitka Island human screening risk assessment is that the predicted lifetime risk values for the mean radionuclide flux from the 19 radionuclides released from the test detonations in 1965, 1969, and 1971 ranged from approximately 10,000-fold to 1,000,000-fold below EPA's point of departure for risk $\left(1.00 \times 10^{-6}\right)$. Even incorporating significant uncertainty into the calculation of radionuclide flux through groundwater and adding additional conservatism in the risk assessment parameters, the risk is still well below the EPA's lower level of concern. These values were predicted for the entire 1,000-year period from 1965 through 2965 for all nine risk scenario combinations of dietary exposure, locations, and groundwater model type. 


\subsection{References}

EPA, see U.S. Environmental Protection Agency.

Hassan, A., K. Pohlmann, and J. Chapman. 2001. Modeling Groundwater Flow and Transport of Radionuclides at Amchitka Island's Underground Nuclear Tests: Milrow, Long Shot, and Cannikin, DOE/NV/11 508-51, Publication No. 45172, 251 p. Las Vegas, NV: Desert Research Institute.

IT, see IT Corporation.

IT Corporation. 1999. Amchitka Subsurface Human Health Risk Assessment Interim Work Product. Las Vegas, NV.

U.S. Environmental Protection Agency. 1998. Risk Assessment Guidance for Superfund: Volume I, Human Health Evaluation Manual (Part D, Standardized Planning, Reporting, and Review of Superfund Risk Assessments), Publication 9285.7-01D. Washington, DC: Office of Emergency and Remedial Response.

U.S. Environmental Protection Agency. 2001. Radionuclide Table: Radionuclide Carcinogencity -Slope Factors. As accessed at http://www.epa.gov/radiation/heast/download.htm on 6 June. 

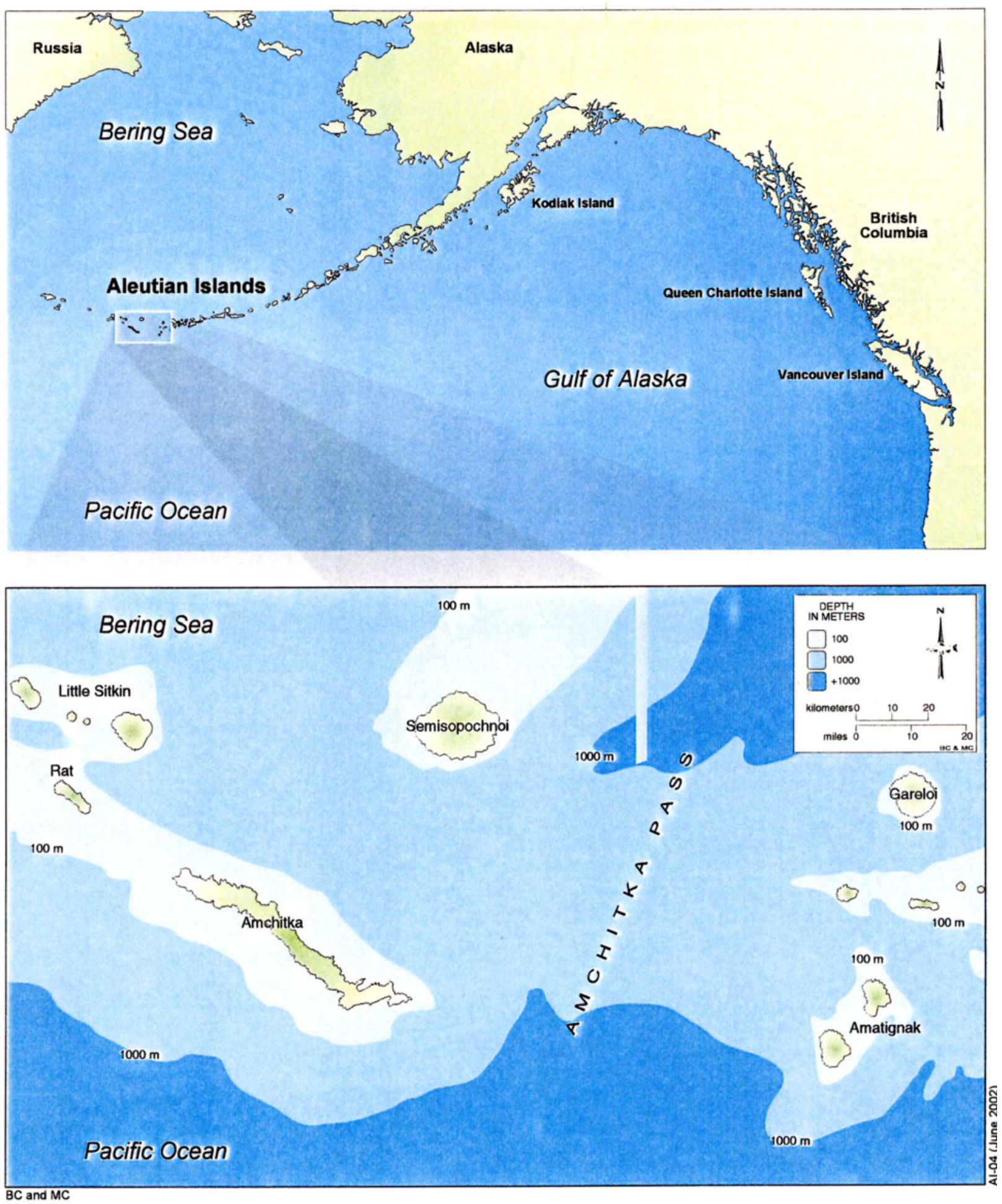

Figure 1

Inset of Amchitka Island and Nearby Islands in Aleutian Islands

Relative to Larger Scale Geography 


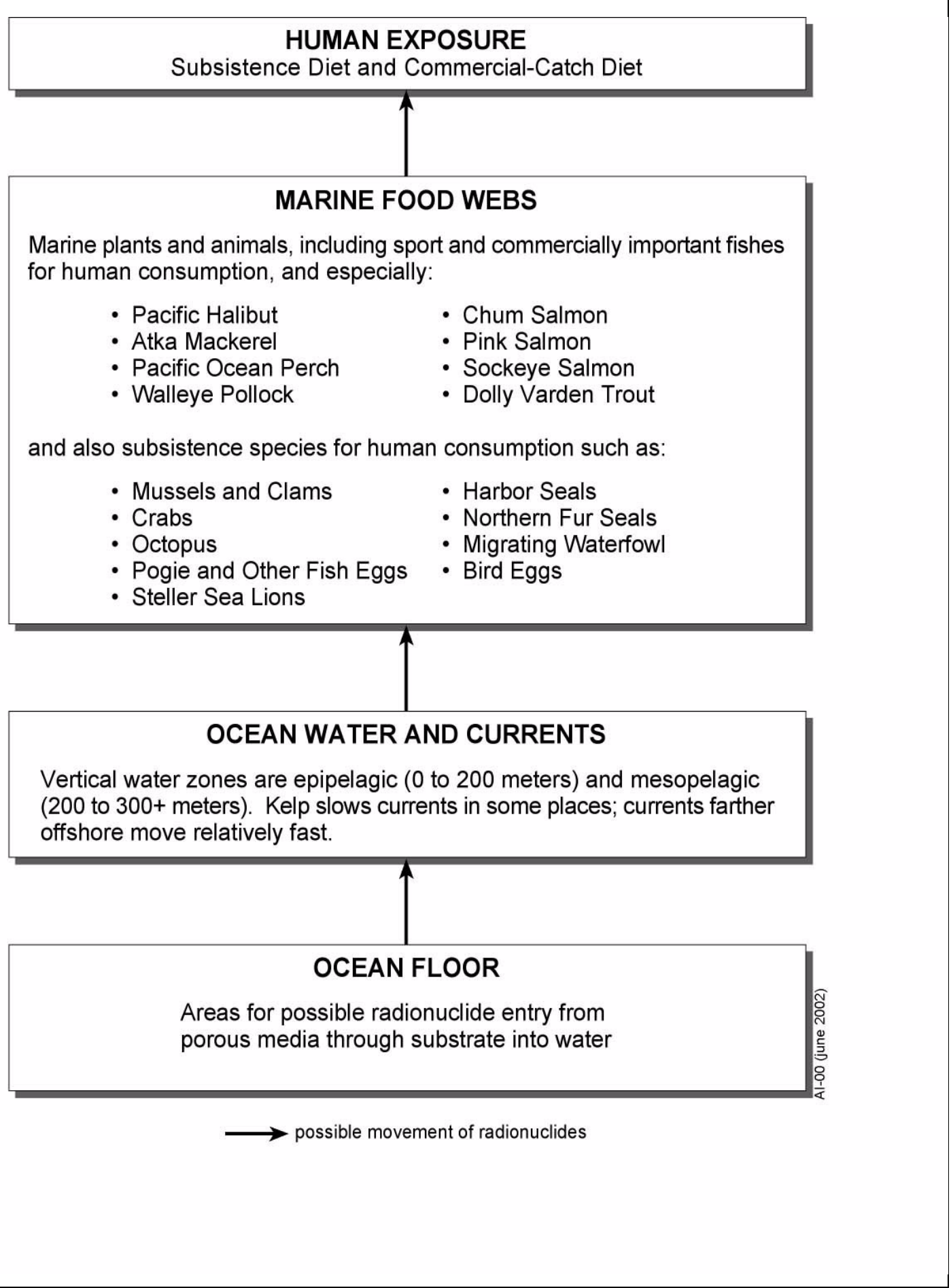

Figure 2

Conceptual Risk Assessment Model 


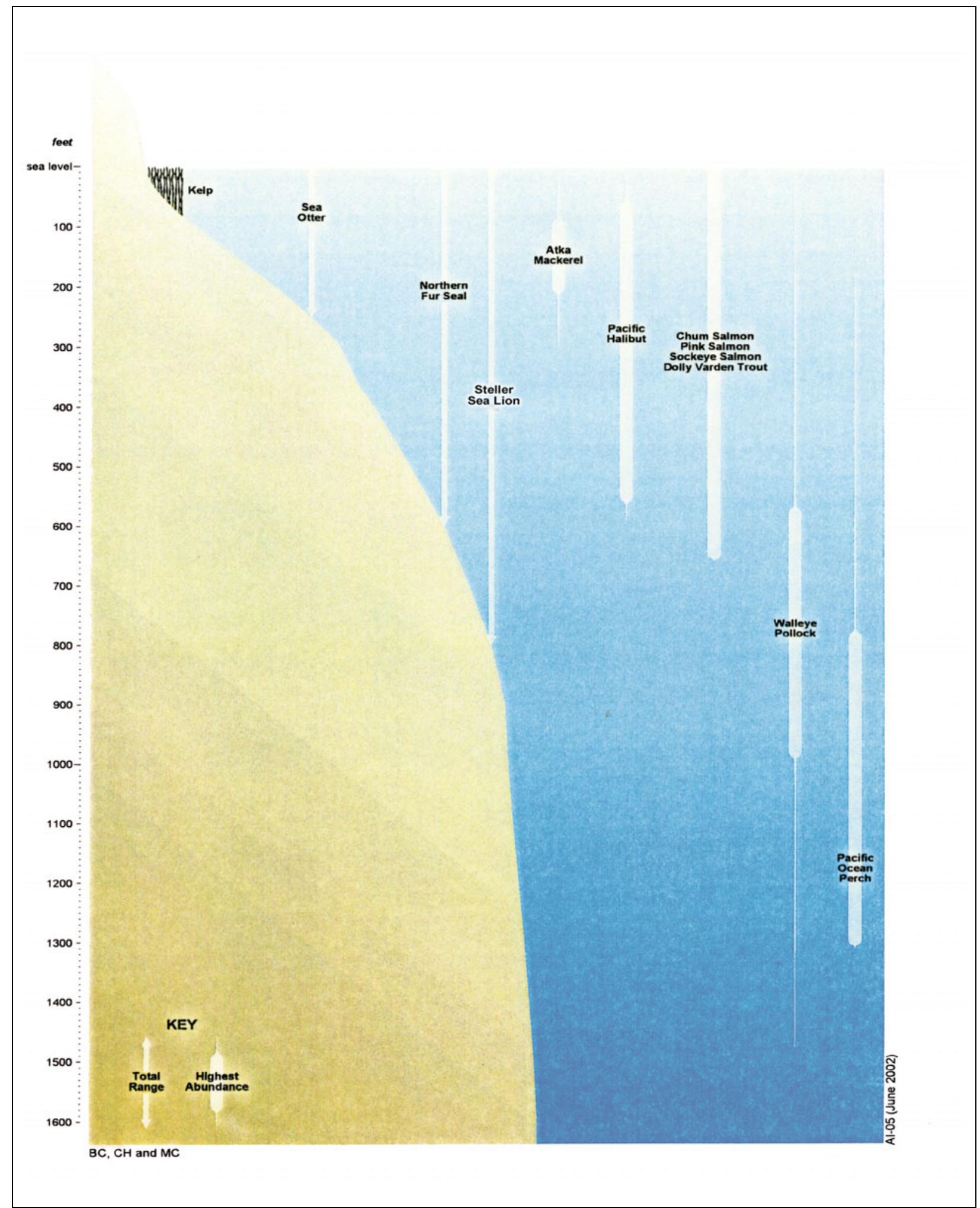

Figure 3

Vertical Zonation or Exposure Depths for Kelp, Marine Mammals, and Marine Fishes Around Amchitka Island 


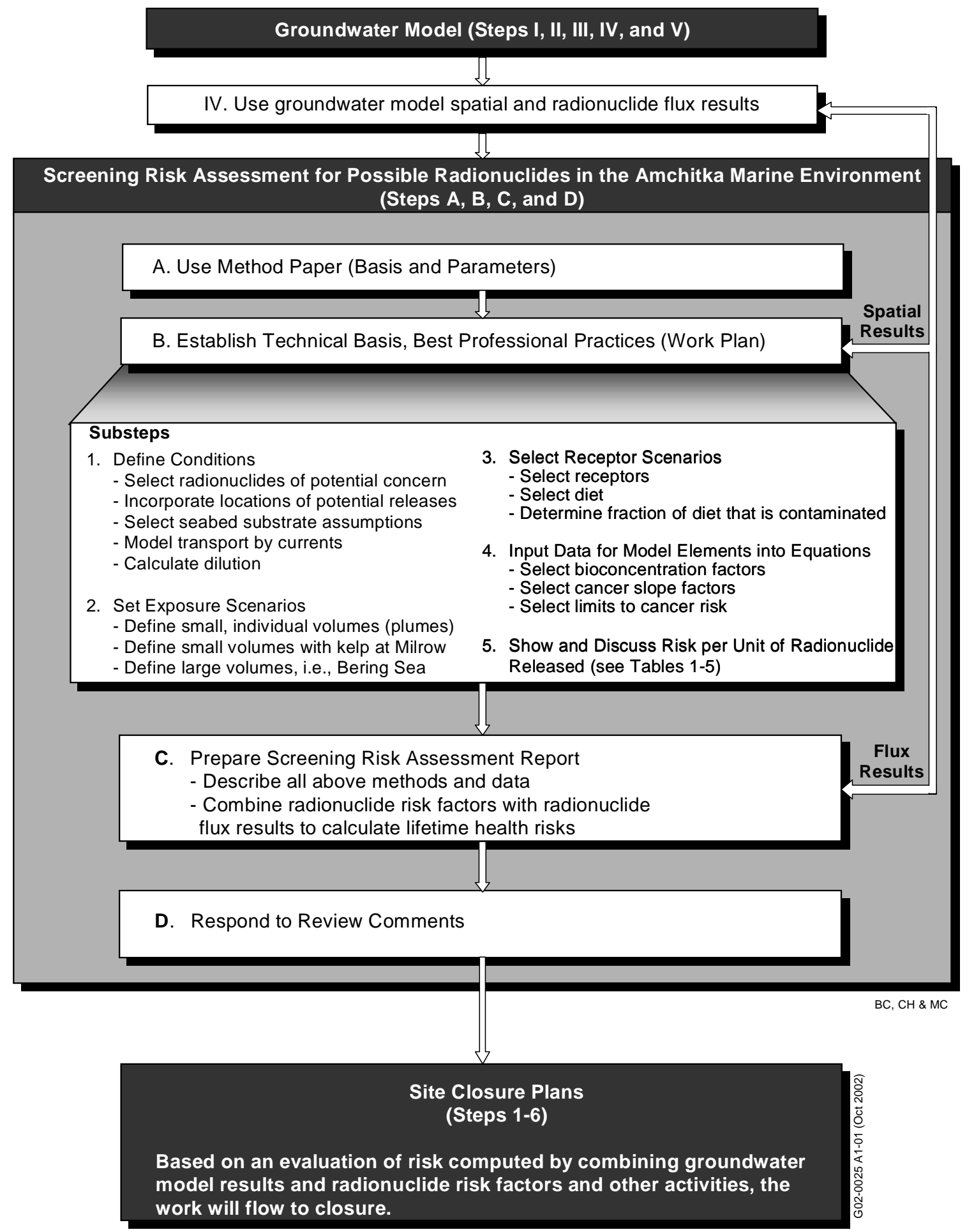

Figure 4

Steps and Substeps in the Screening Risk Assessment Relative to the Groundwater Model and Site Closure Plans 


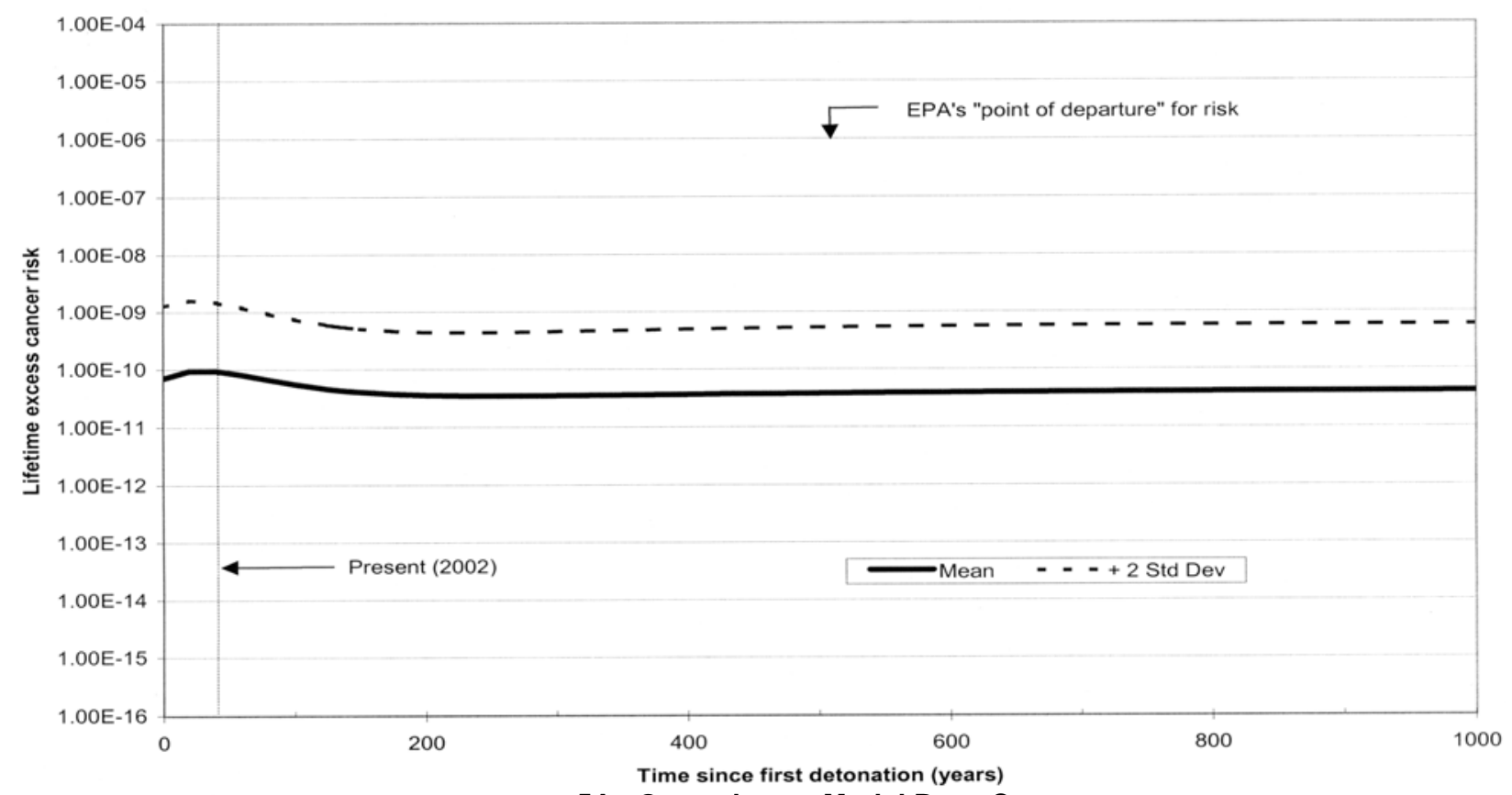

5A. Groundwater Model Base Case

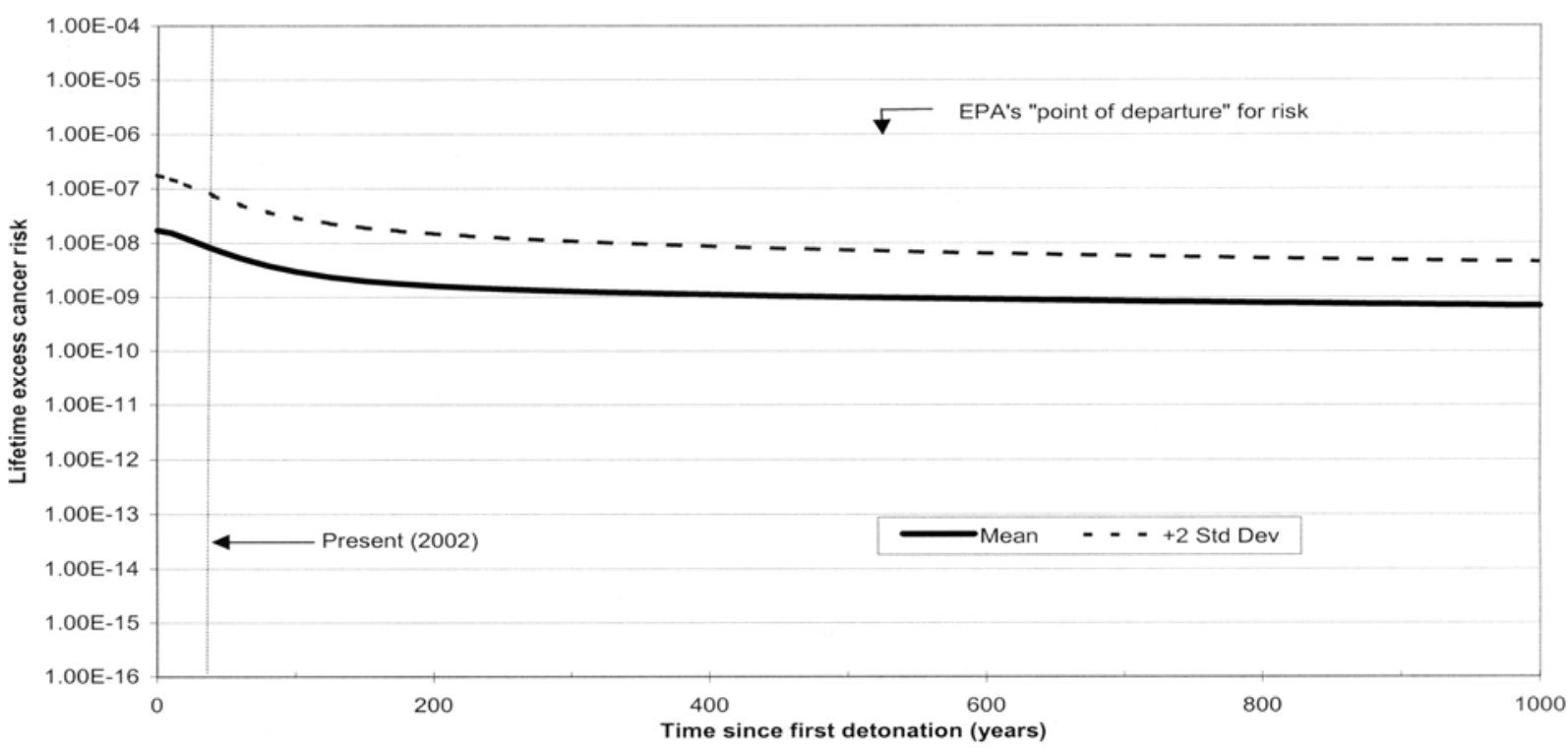

5B. Groundwater Model Sensitivity Case

Figure 5

Scenario 1 - Fish Subsistence Diet for Combined Cannikin, Long Shot, and Milrow (No Kelp) 


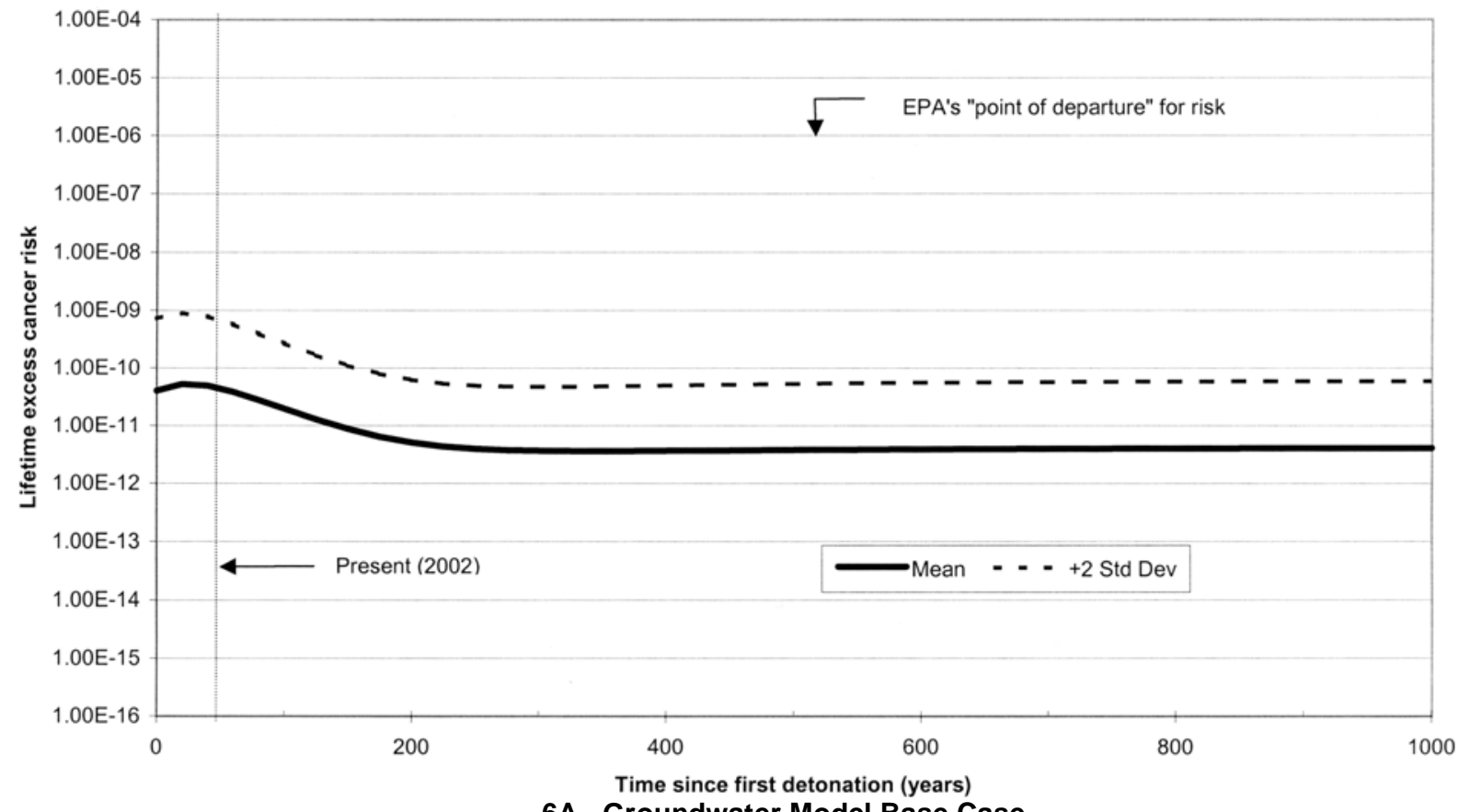

6A. Groundwater Model Base Case

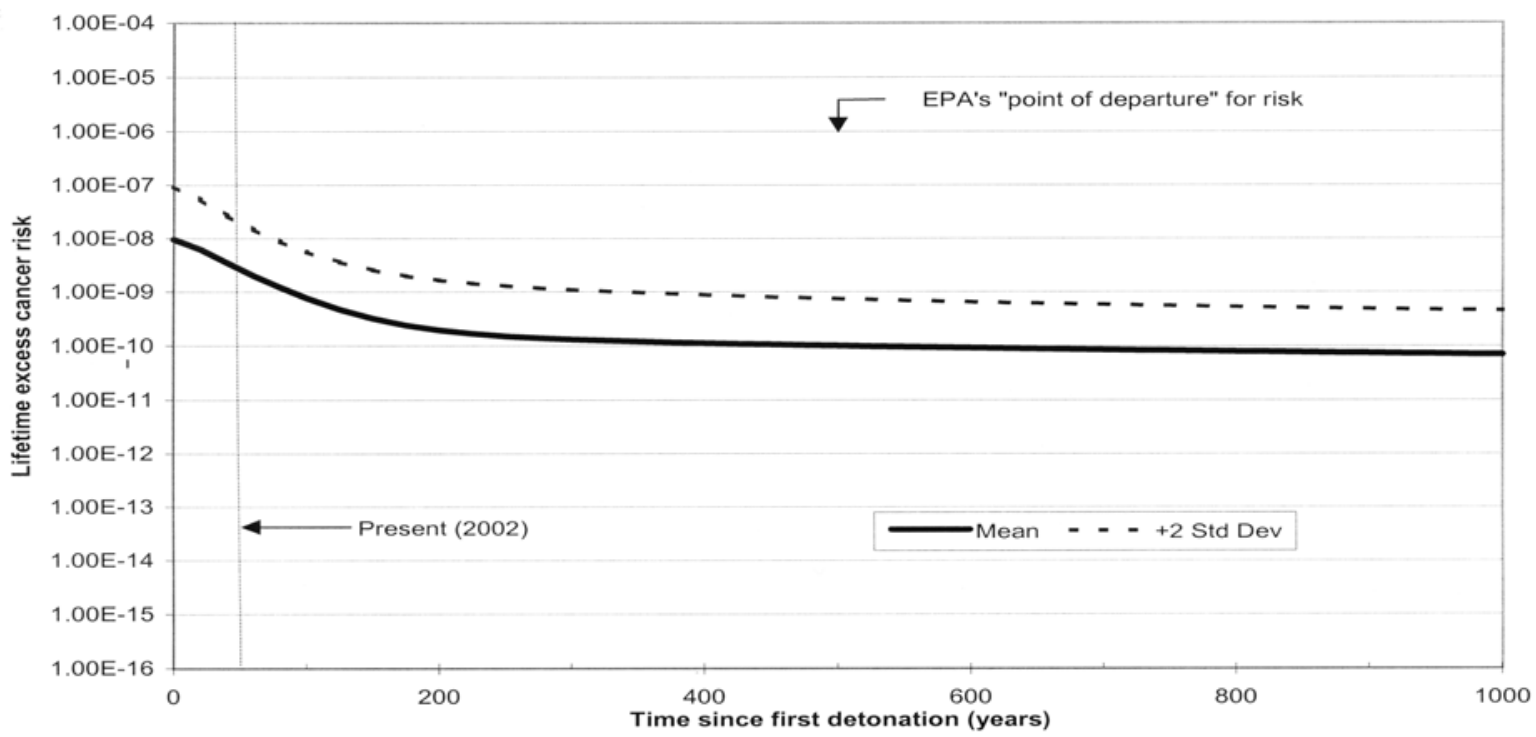

6B. Groundwater Model Sensitivity Case

Figure 6

Scenario 2 - Mammal Subsistence Diet for Combined Cannikin, Long Shot, and Milrow (No Kelp) 


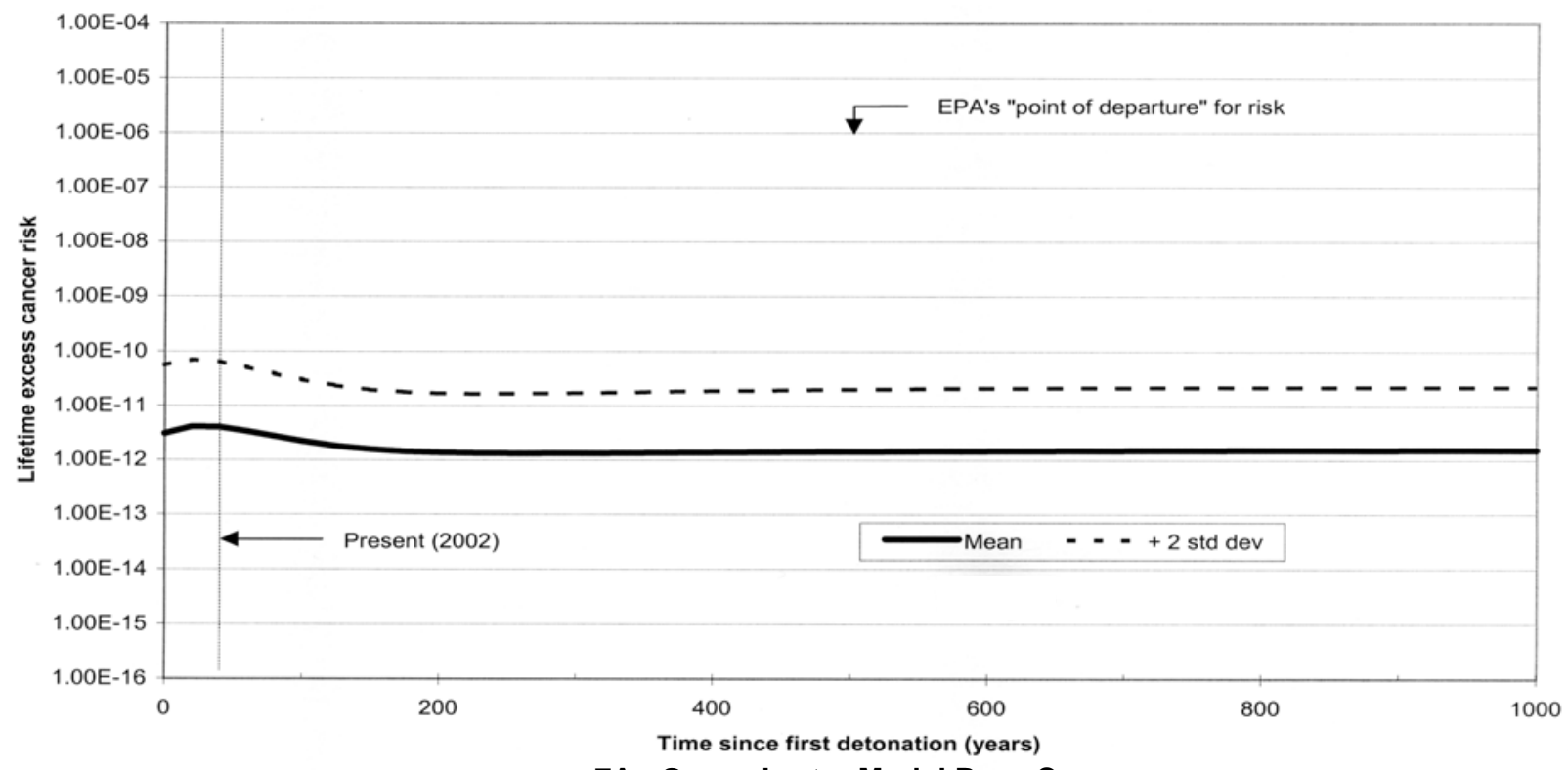

7A. Groundwater Model Base Case

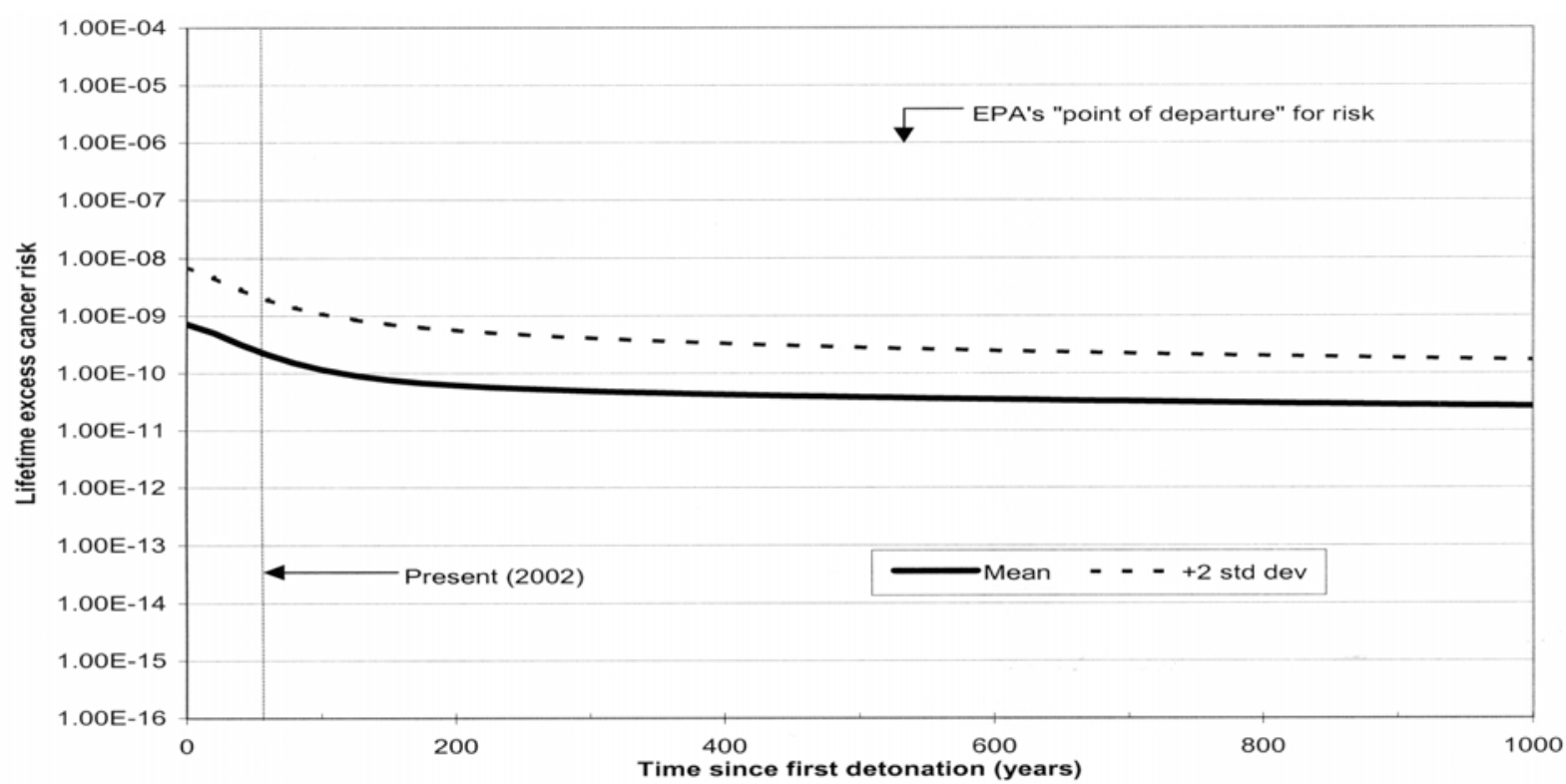

7B. Groundwater Model Sensitivity Case

Figure 7

Scenario 3 - Commercial Catch Diet for Combined Cannikin, Long Row, and Milrow (No Kelp) 


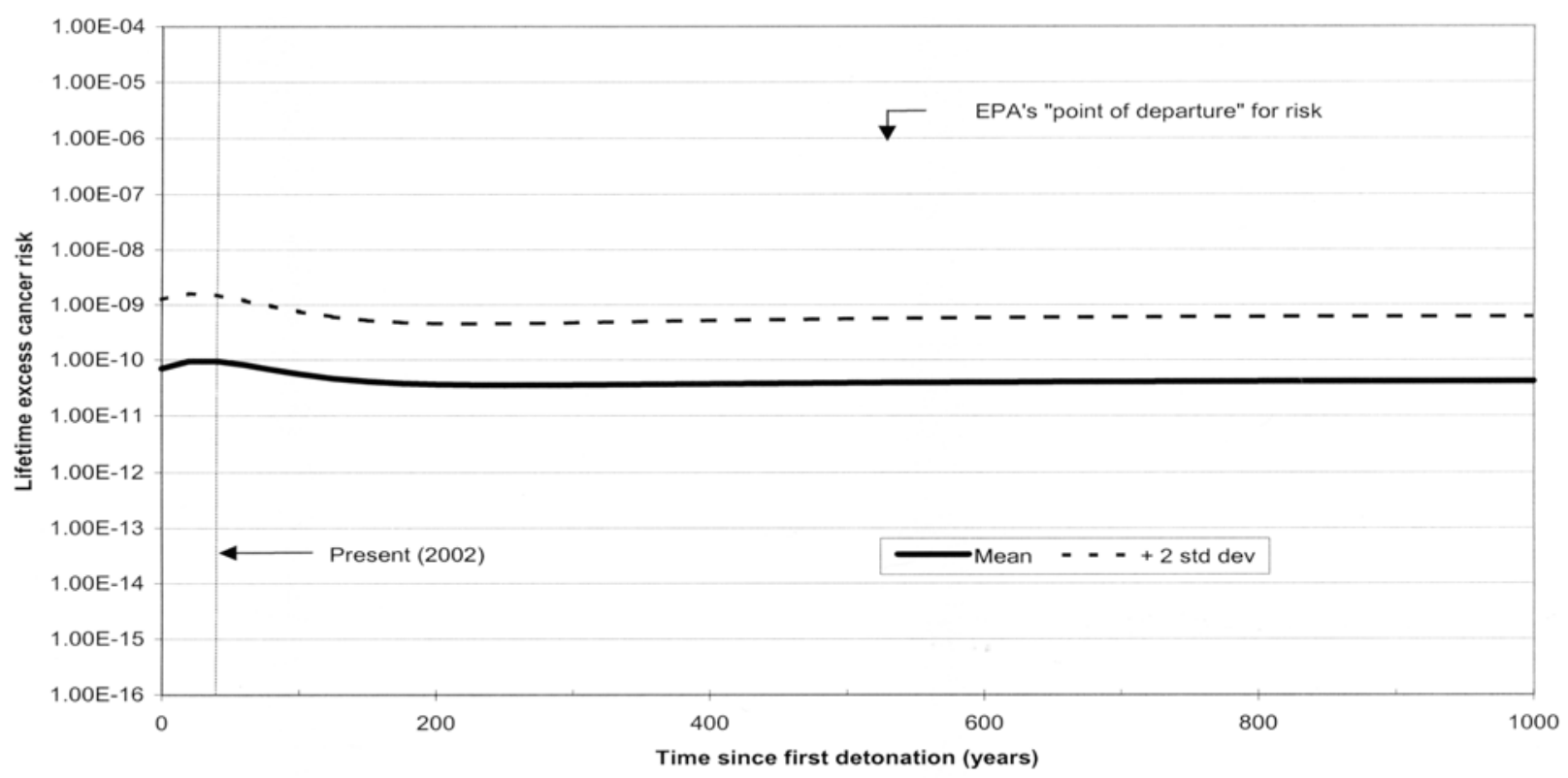

8A. Groundwater Model Base Case

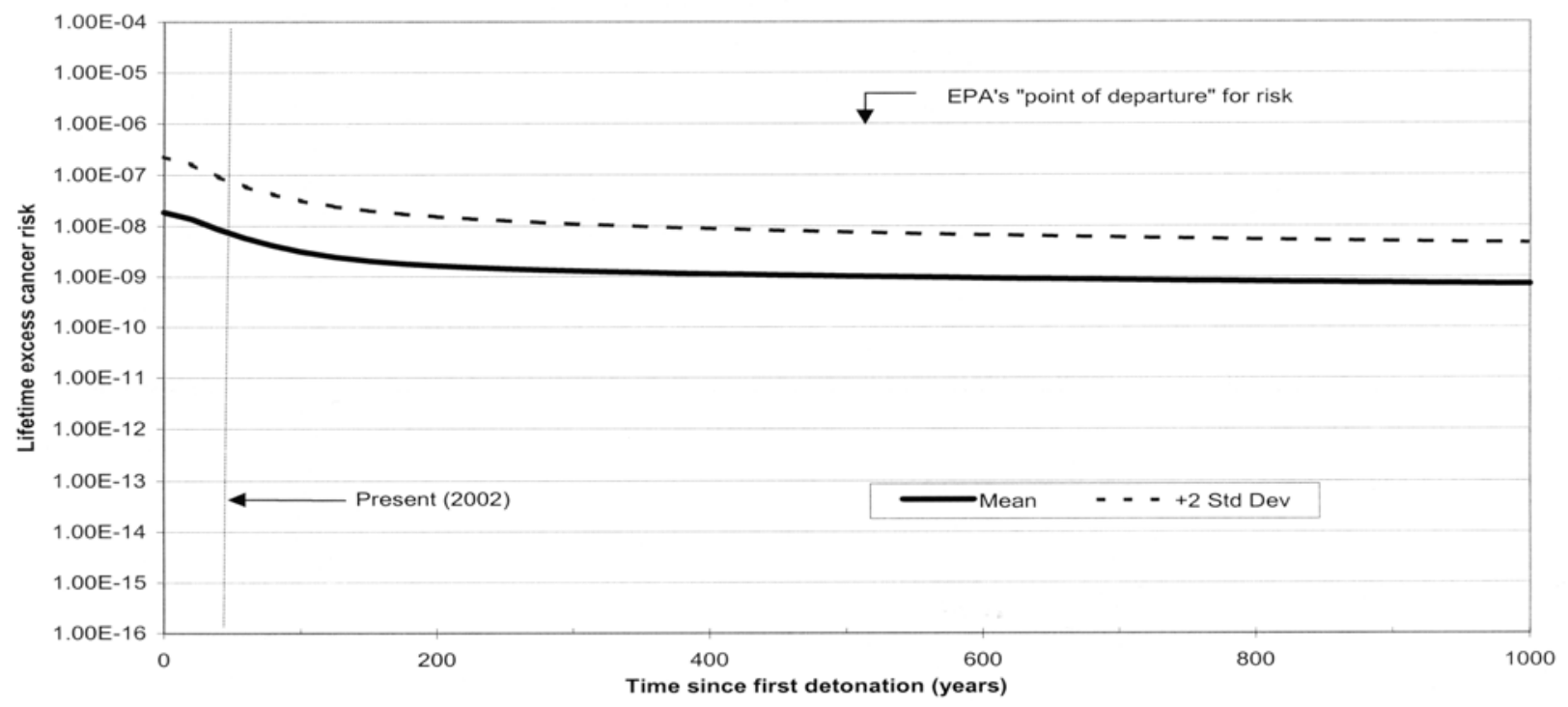

8B. Groundwater Model Sensitivity Case

Figure 8

Scenario 4 - Fish Subsistence Diet for Combined Cannikin, Long Shot, and Milrow (With Kelp) 


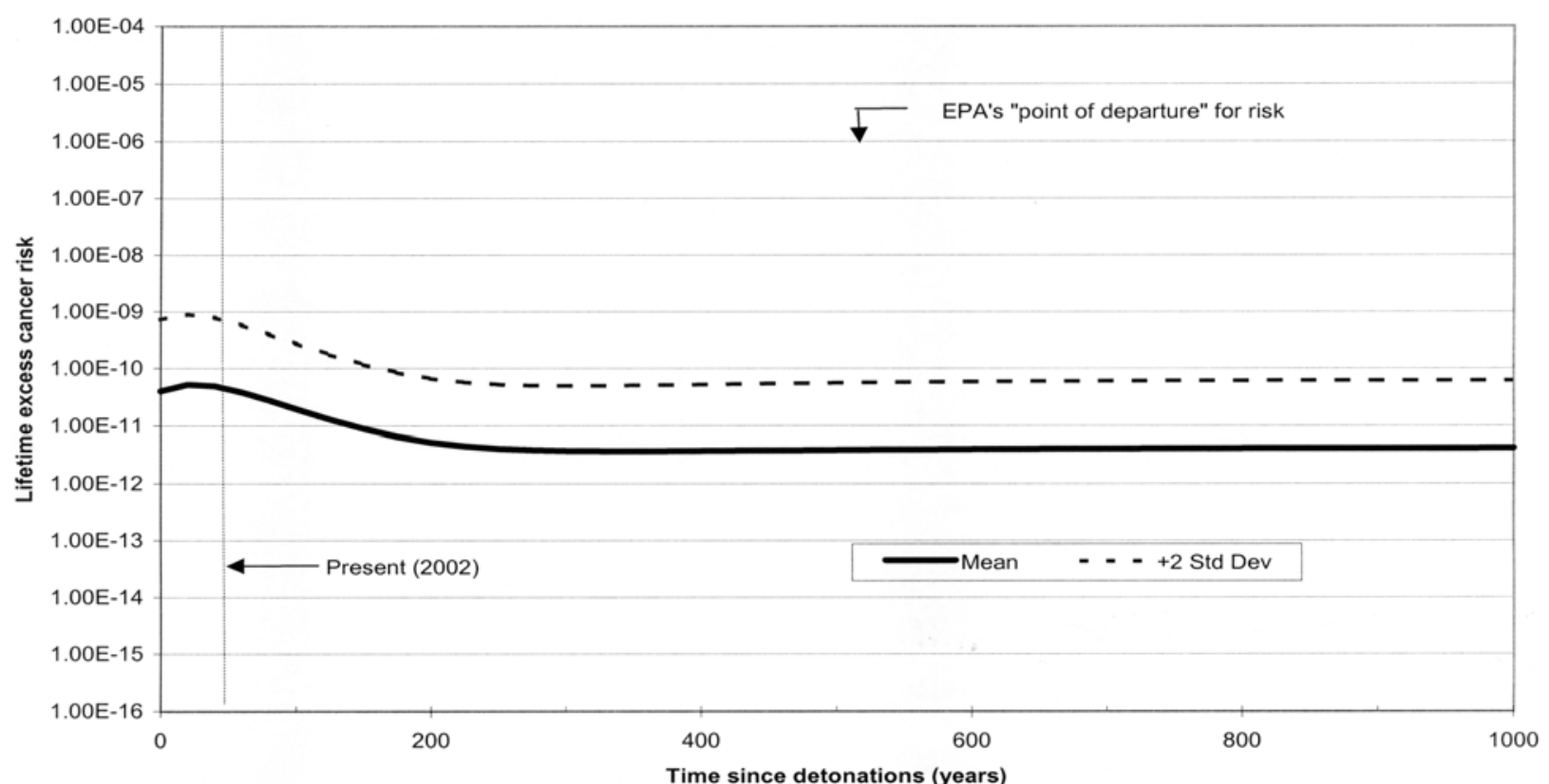

9A. Groundwater Model Base Case

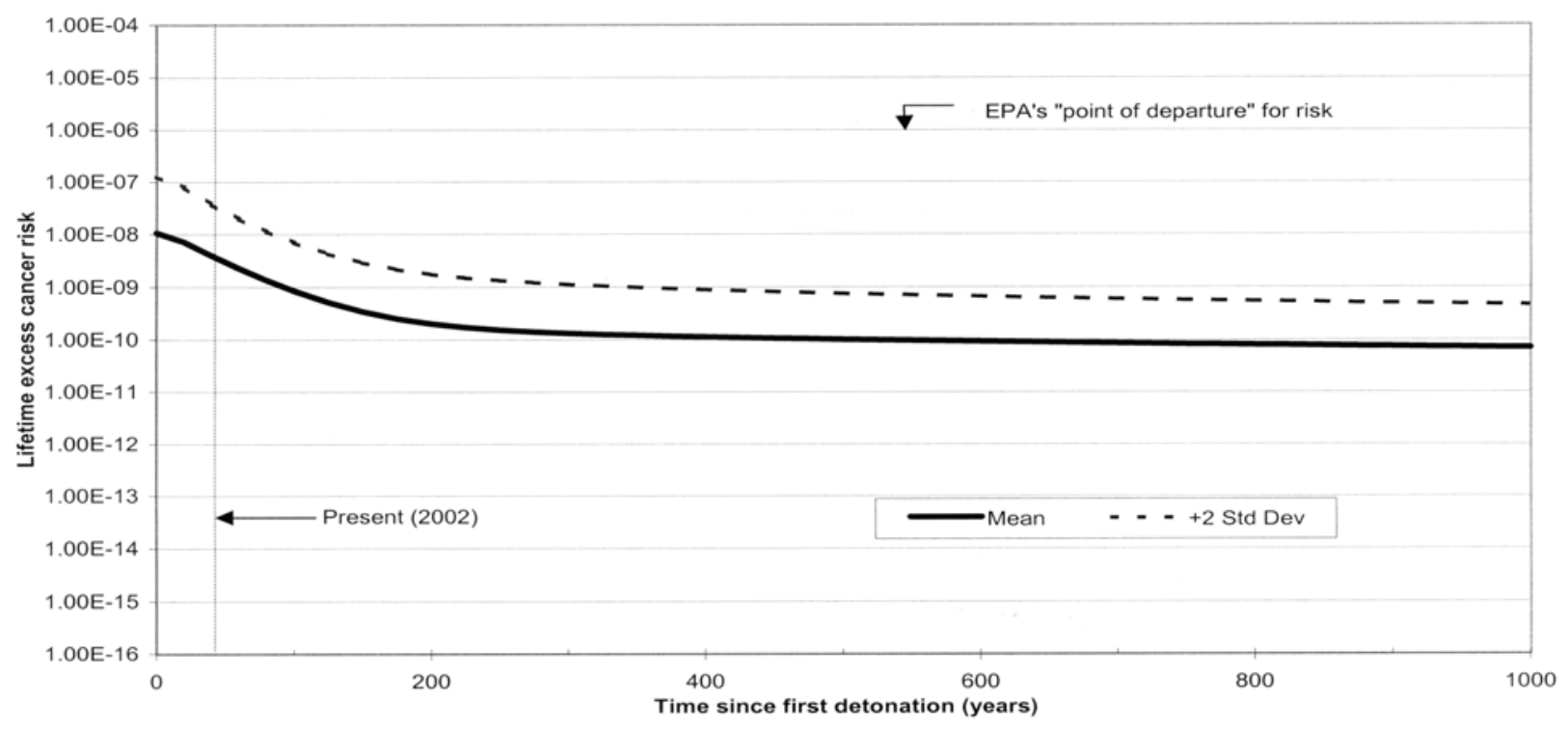

9B. Groundwater Model Sensitivity Case

Figure 9

Scenario 5 - Mammal Subsistence Diet for Combined Cannikin, Long Shot, and Milrow (With Kelp) 


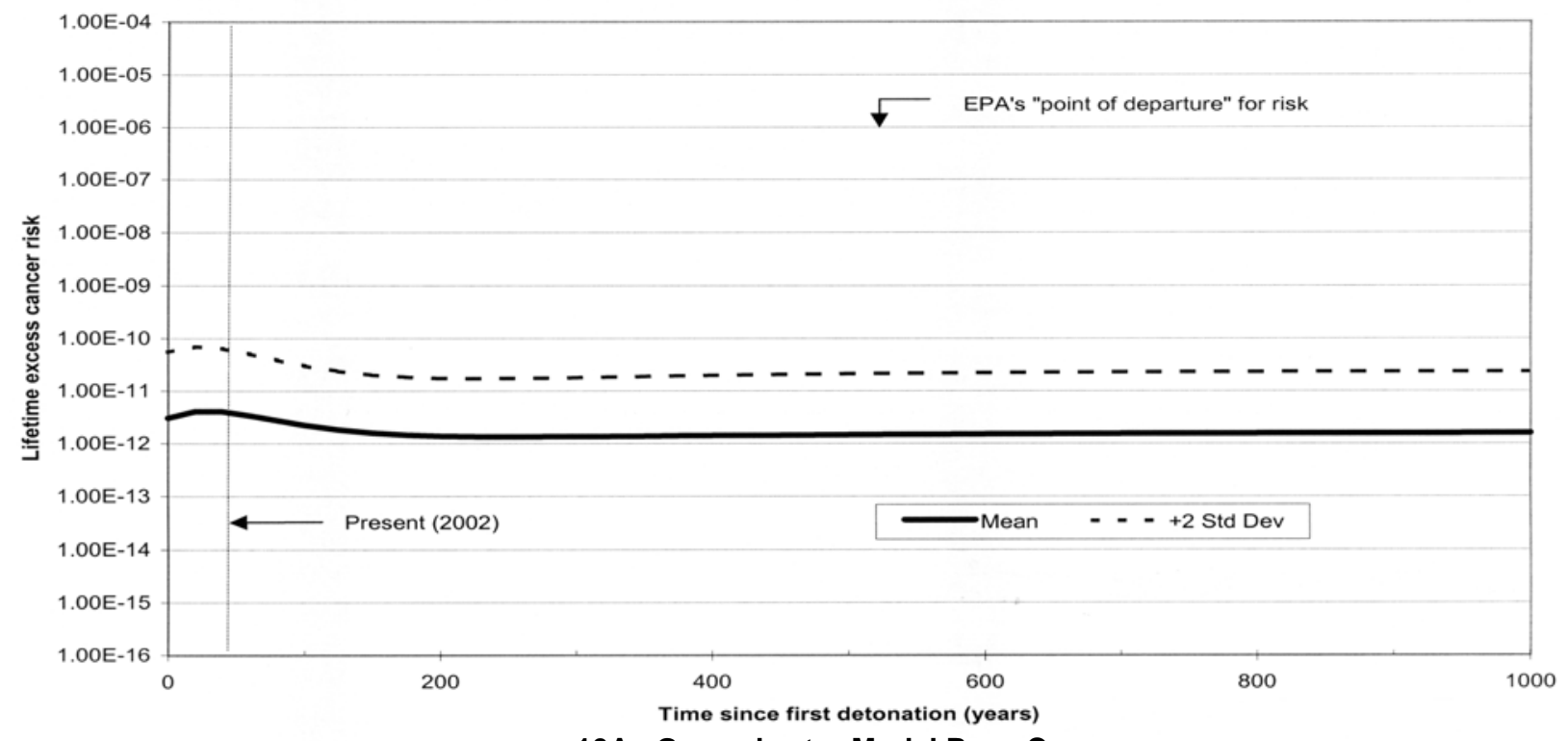

10A. Groundwater Model Base Case

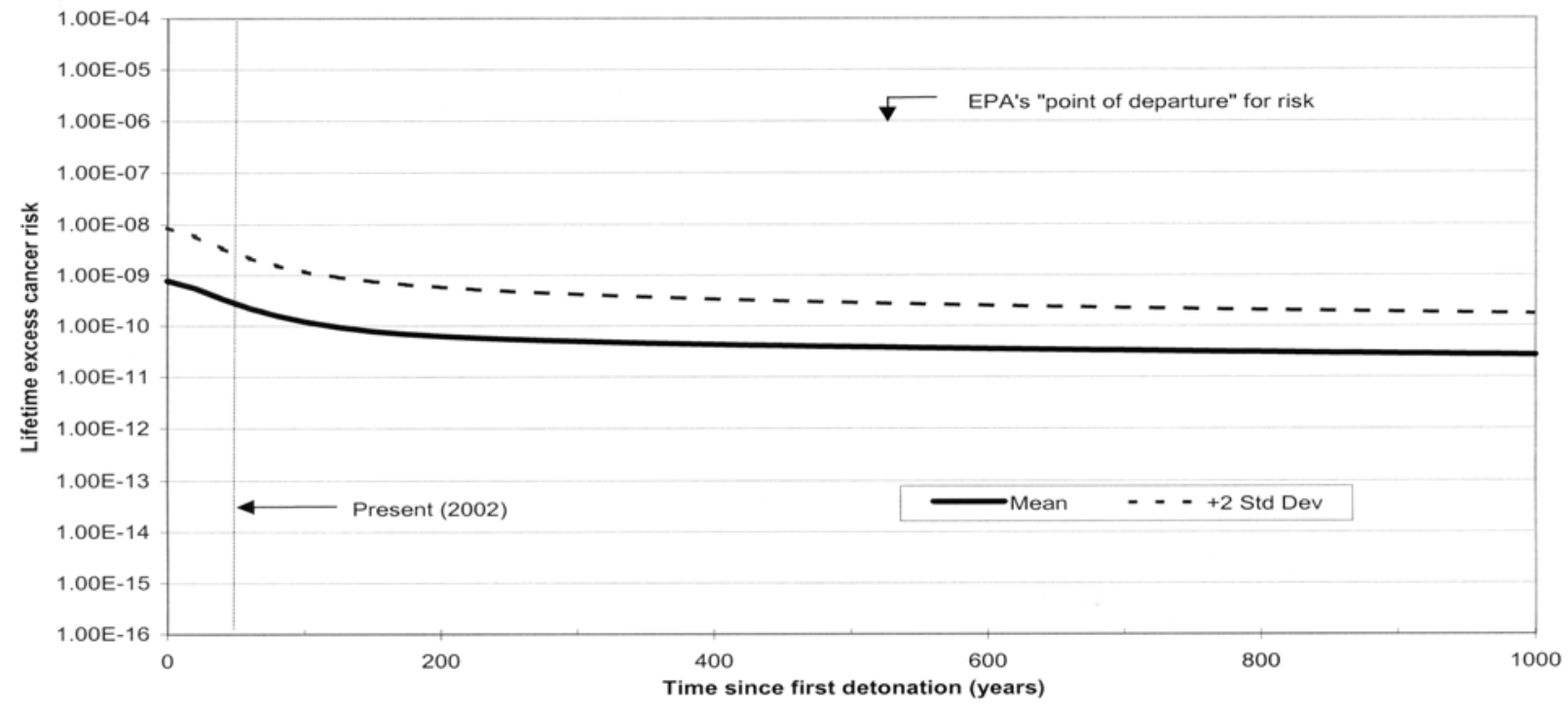

10B. Groundwater Model Sensitivity Case

Figure 10

Scenario 6 - Commercial Catch Diet for Combined Cannikin, Long Shot, and Milrow (With Kelp) 


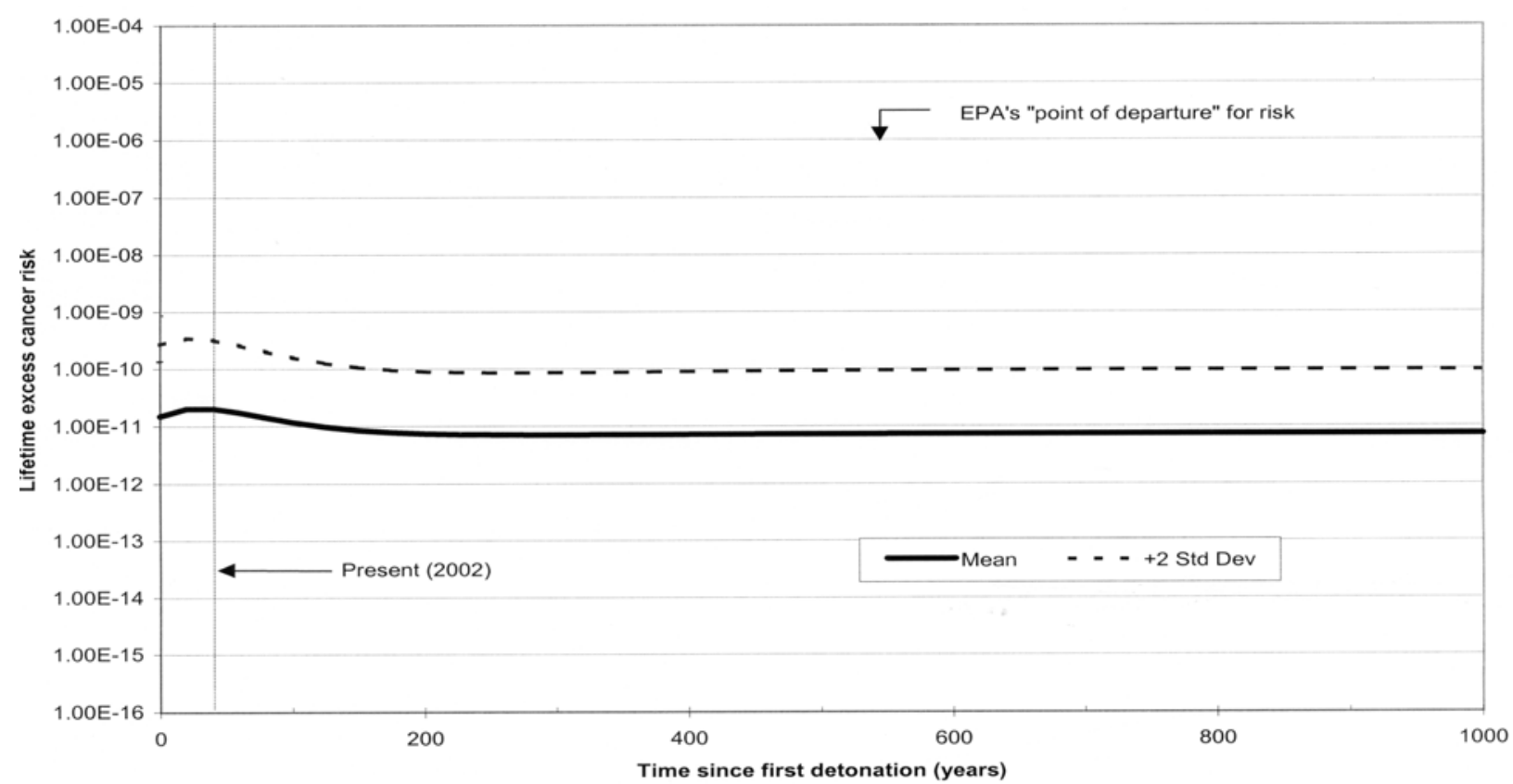

11A. Groundwater Model Base Case

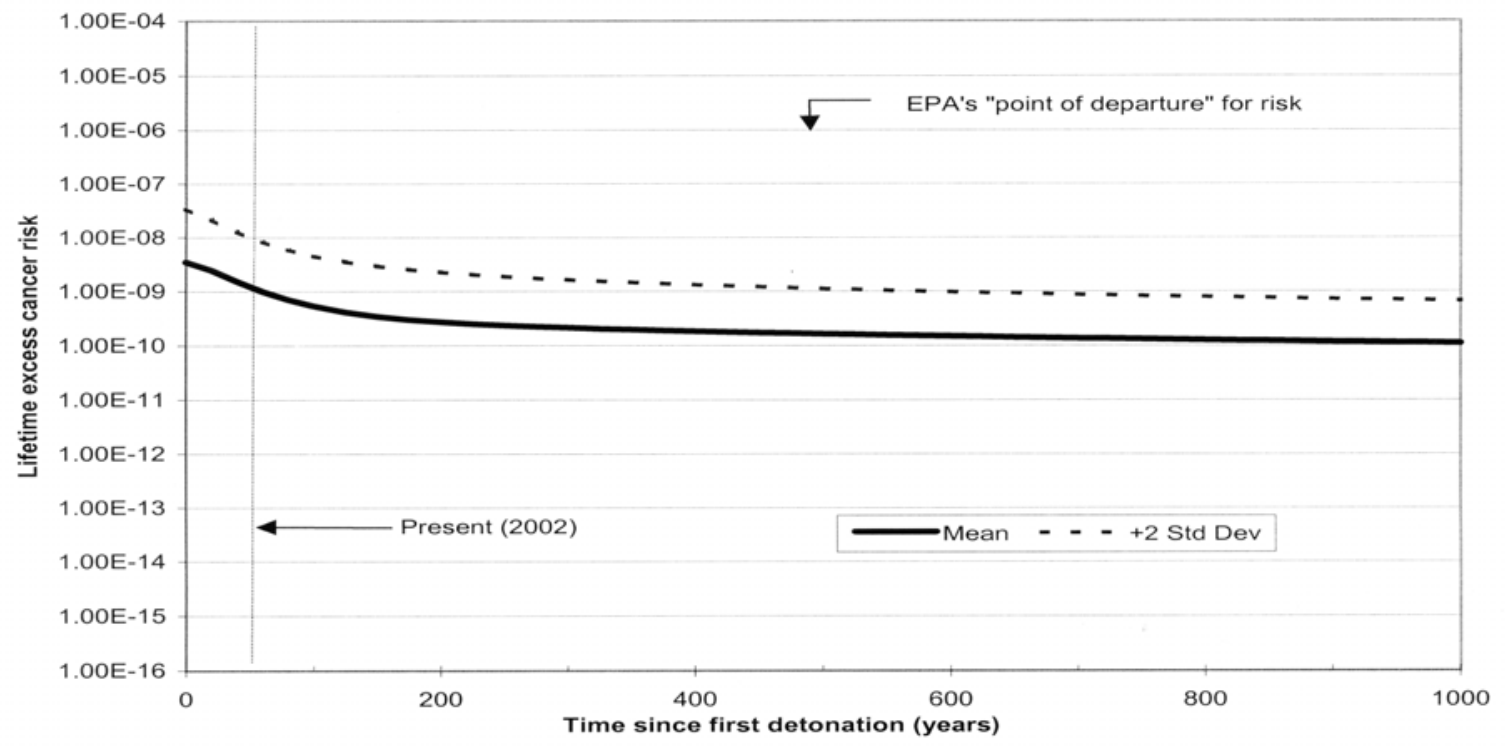

11B. Groundwater Model Sensitivity Case

Figure 11

Scenario 7 - Fish Subsistence Diet for Aleut Culture and Communication Area 


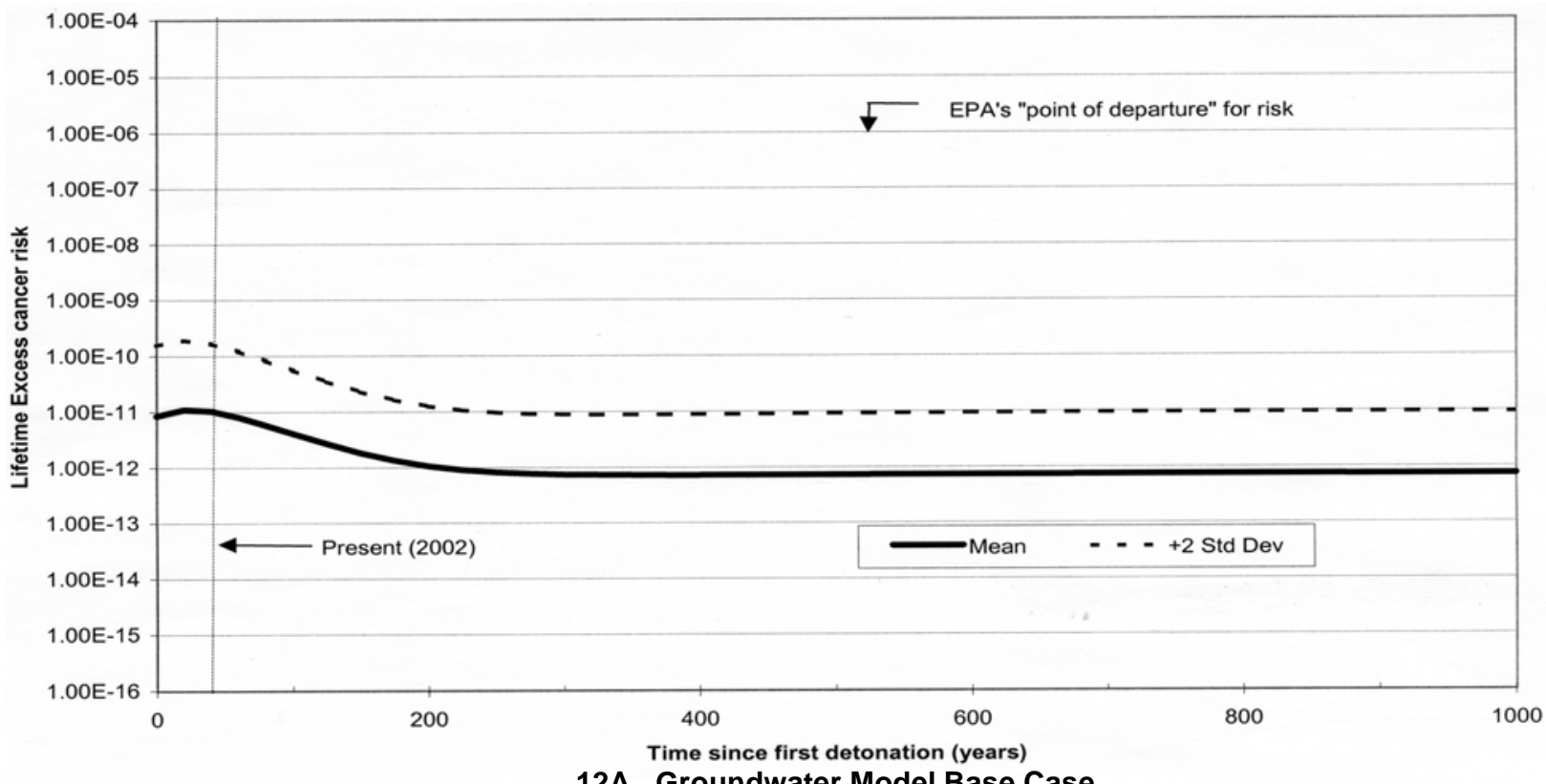

12A. Groundwater Model Base Case

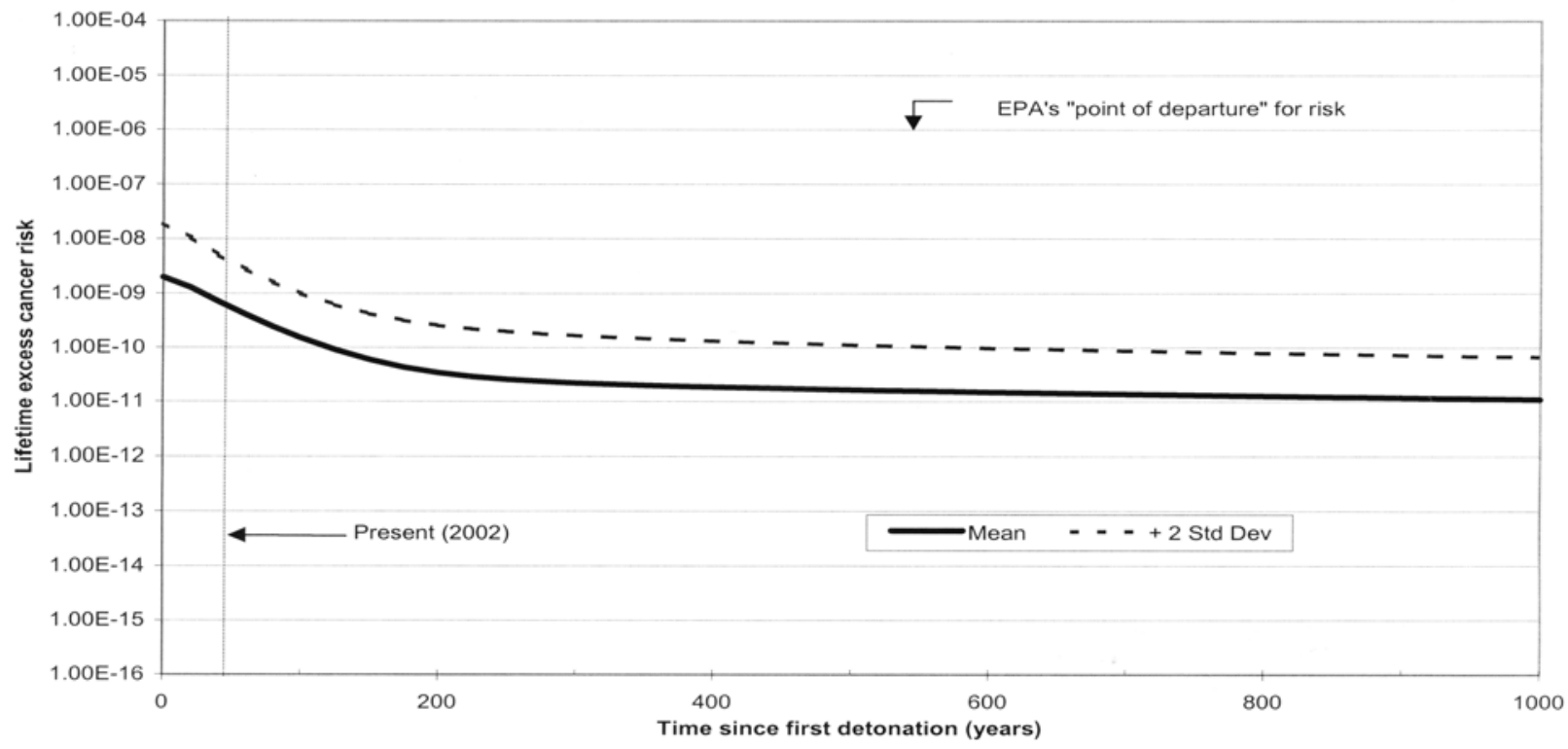

12B. Groundwater Model Sensitivity Case

Figure 12

Scenario 8 - Mammal Subsistence Diet for Aleut Culture and Communication Area 


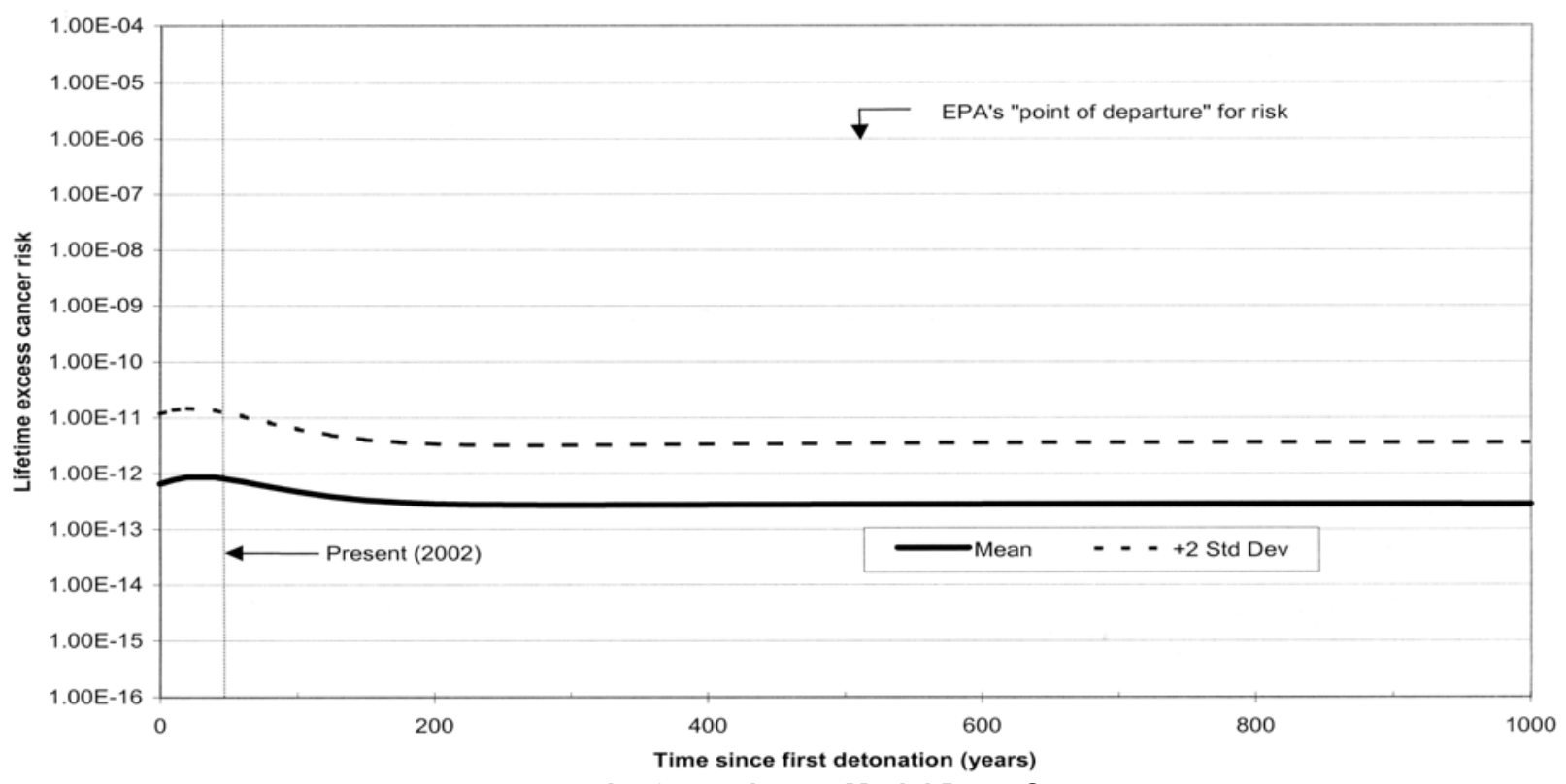

13A. Groundwater Model Base Case

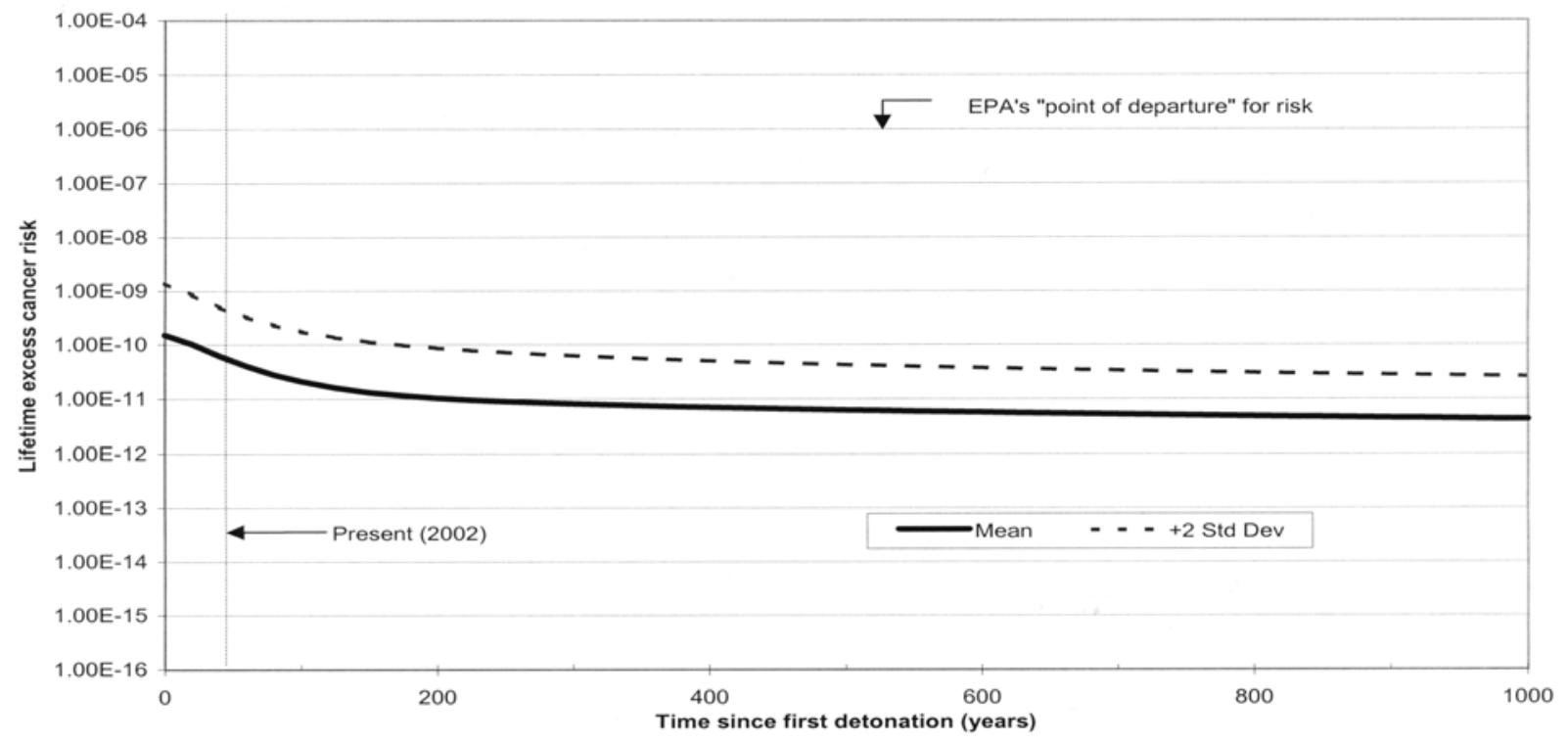

13B. Groundwater Model Sensitivity Case

Figure 13

Scenario 9 - Commercial Catch Diet for Aleut Culture and Communication Area 


\section{Appendix A}

Exposition of Major Modeling Elements of Screening Risk Assessment for Possible Radionuclides in the Amchitka Marine Environment 


\section{A.1.0 Introduction}

This appendix describes 11 major elements of the model for two types of human exposure (i.e., subsistence users and commercial catch consumers) to possible radionuclides from nuclear tests on Amchitka Island. Specifically, the model focuses on 19 radionuclides associated with the Amchitka tests that might be transported by groundwater to the seafloor. The document also summarizes the current state of our knowledge about the modeling elements and the use of the available data for the risk assessment modeling.

Model elements have been advanced in a series of intermediate reports that have received DOE and stakeholder inputs. The elements are identified to the right of a schematic (Figure A.1) that shows the inputs that are required to describe the possible flow of radionuclides from the ocean floor to native Alaskan consumers of marine biota (subsistence users) and consumers of commercial catches. Those elements, progressing from release at the bottom of the schematic to human intake at the top of the schematic, are as follows:

1. Radionuclides of potential concern

2. Locations of releases

3. Seabed substrates

4. Transport by currents

5. Dilution including plume

6. Human receptors

7. Distribution of diet

8. Bioconcentration factors

9. Fraction of contaminated diet

10. Cancer morbidity risk coefficients

11. Limits to cancer risk 
The following text discusses each element, starting with the ROPCs through transport and diet and ending with the limits to cancer risk. Cancer risk is initially expressed as a radionuclide risk factor, which was multiplied by the predicted radionuclide fluxes to compute cumulative risks from food eaten by the subsistence user or commercial catch consumer. Discussion of each element begins with a description, presents current knowledge, and then describes how the process is being implemented. 


\section{A.2.0 Radionuclides of Potential Concern}

\section{A.2.1 Description}

Nineteen radionuclides were chosen for this study. They are radionuclides that (1) could have been present in, or produced by, the nuclear devices detonated on Amchitka; (2) have sufficiently long half-lives (> 10 years) to be an ongoing concern; and (3) have published BCFs and CMRCs.

\section{A.2.2 Current Knowledge}

The initial hydrogeological modeling approach included 24 radionuclides or decay products (DRI, 1999) obtained from the Smith (1997) list of significant radionuclides and classified sources. Five nuclides were eliminated: krypton-85, which is a gas and has no CMRC; and rubidium-85, zirconium-90, barium-137, and europium-151, which are nonradioactive decay products. This resulted in 19 radionuclides. The $\mathrm{BCF}$ is a measure of the transfer of radionuclide from an abiotic medium (e.g., seawater) through the food chain to a receptor (e.g., fish), and the CMRC is a measure of the lifetime risk of excess cancers in humans per picocurie of radiation absorbed. The remaining 19 radionuclides are listed on Table A-1.

\section{A.2.3 Discussion of Uncertainties}

The radionuclides of potential concern were chosen from radionuclides produced by nuclear testing that are well known based upon theoretical physics and observation. An inventory of 57 radionuclides with half-lives in excess of 10 years has been compiled in classified reports for each of the experiments conducted beneath the NTS and those conducted off the NTS. Similar information is available in unclassified reports (Smith 1995; Bowen et al., 2001). The 19 radionuclides modeled for this risk assessment were selected using these sources. 
Table A-1

Radionuclides Selected for Hydrogeological and Risk Assessment Modeling

\begin{tabular}{|c|c|c|c|}
\hline Radionuclide & $\begin{array}{c}\text { Present } \\
\text { in } \\
\text { Nuclear } \\
\text { Devices }\end{array}$ & $\begin{array}{c}\text { Produced } \\
\text { by Nuclear } \\
\text { Devices }\end{array}$ & $\begin{array}{c}\text { Half-Life } \\
\text { (Year) }\end{array}$ \\
\hline Tritium & Yes & & $1.24 \mathrm{E}+01$ \\
\hline Carbon-14 & & Yes & $5.73 E+03$ \\
\hline Chlorine-36 & & Yes & $3.01 \mathrm{E}+05$ \\
\hline Strontium-90 & & Yes & $2.91 \mathrm{E}+01$ \\
\hline Yttrium-90 ${ }^{\mathrm{a}}$ & & Yes & 7.30E-03 \\
\hline Technetium-99 & & Yes & $2.13 \mathrm{E}+05$ \\
\hline lodine-129 & & Yes & $1.57 \mathrm{E}+07$ \\
\hline Cesium-137 & & Yes & $3.00 \mathrm{E}+01$ \\
\hline Samarium-151 & & Yes & $9.00 \mathrm{E}+01$ \\
\hline Europium-152 & & Yes & $1.33 \mathrm{E}+01$ \\
\hline Gadolinium-152 & & Yes & $1.08 E+14$ \\
\hline Uranium-234 & Yes & & $2.45 E+05$ \\
\hline Uranium-236 & Yes & & $2.34 \mathrm{E}+07$ \\
\hline Uranium-238 & Yes & & 4.47E+09 \\
\hline Neptunium-237 & Yes & & $2.14 \mathrm{E}+06$ \\
\hline Plutonium-239 & Yes & & $2.41 \mathrm{E}+04$ \\
\hline Plutonium-240 & Yes & & $6.54 \mathrm{E}+03$ \\
\hline Plutonium-241 & Yes & & $1.44 \mathrm{E}+01$ \\
\hline Americium-241 & Yes & & $4.32 \mathrm{E}+02$ \\
\hline
\end{tabular}

\footnotetext{
${ }^{\mathrm{a}}$ Retained because yttrium- 90 is a daughter of strontium- 90 .
} 
The accuracy of a particular inventory depends in large part on the source of information for the included nuclides. Nuclides whose abundances were measured directly (from post-detonation core samples) are more accurate than those based on device characteristics and performance.

Bowen et al. (2001) estimate the accuracies for nuclide groups as follows:

Fission products $\quad \sim 10 \%$ to $30 \%$ for most fission products

Unspent fuel material $\quad 20 \%$ or better

Fuel activation products $\sim 50 \%$ or better

Residual tritium $\quad \sim 300 \%$ or better

Activation products $\quad \sim$ a factor of 10

It is assumed the group of 19 radionuclides are expected to contribute the most to potential risk from nuclear testing at Amchitka.

\section{A.2.4 Implementation}

The radionuclides shown in Table A-1 were used for the risk modeling. 


\section{A.3.0 Locations of Releases}

\section{A.3.1 Description}

Contaminants are hypothesized to be transported to the seabed by groundwater flow. The time and location of the releases likely determine the subsequent transport by currents, dilution and plume size and shape, uptake by local biota, and other factors described by the model elements.

\section{A.3.2 Current Knowledge}

Groundwater modeling was done to predict the locations, time elapsed after the test detonations, duration, and rates of release. The use of this information for the risk assessment is discussed below. Additional information is provided in this section to illustrate the locations of the potential releases and provide a perspective on the locations of the radionuclide sources relative to the Amchitka environment (e.g., the Pacific Ocean and the Bering Sea).

\section{A.3.2.1 Groundwater Modeling}

Groundwater modeling was conducted by DRI in Las Vegas, Nevada. Preliminary results showed that tritium could be released to the seabed over a period of several decades and over distances from $\sim 0.25$ to $\sim 4.5 \mathrm{~km}$ from the shoreline. Tritium is assumed to move with the speed of groundwater, while other radionuclides may be retarded by interactions with components of the subsurface medium. The degree of retardation depends on chemical properties of the radionuclides and other factors.

Island hydraulics dictate that a groundwater divide runs along the long axis of Amchitka, separating groundwater flow to the Bering Sea from that of the Pacific Ocean. The Cannikin and Long Shot sites are north of the groundwater divide, and the Milrow site is south of the groundwater divide. Therefore, it is assumed that potential releases from Long Shot and Cannikin are into the Bering Sea, whereas potential releases from Milrow are into the Pacific Ocean. The predicted locations of the releases are shown in Figure A.2. This figure shows the location of each test as a dot on a line perpendicular to the general trend of the island. The approximate groundwater divide is shown as a bar at the centerline of the island and on the transverse line through the test site. 
Uncertainty in some input parameters concerning the groundwater flow system and behavior of substances during subsurface transport result in a distribution of locations where groundwater is predicted to emerge at the seabed when the model is run many times. This is because the groundwater model is a probabilistic model in which uncertain parameter values can vary each time the computation is done. The location nearest to the shore where releases are predicted to occur is termed the "first edge." Similarly, the location farthest from the shore where releases are predicted to occur is termed the "second edge." For this evaluation, the groundwater model produced a distribution of hundreds of predicted first and second edges. The nearest predicted first edge and the farthest predicted second edge are shown on Figure A.2 as bars on the transverse lines. The 75- and 300-ft isobaths around Amchitka are labeled to facilitate understanding of further discussion about depths. The perpendicular lines at each site are also locators for cross-section drawings of the sites, which will be presented in the next subsection.

Due to the uncertainty about the location of releases, the risk assessment uses the $5^{\text {th }}$ percentile lower bound of the distribution of the first edge to define the shoreward edge of the zone of release. The $95^{\text {th }}$ percentile upper bound of the distribution of the second edge was used to define the seaward edge of the release for all three sites. The 75-ft isobath was used to define the area in which stands of kelp and slow currents are expected to occur. The distance of the 75-ft depth from the shoreline on a line perpendicular to the island's axis was measured on a map. The locations of the first and second edges bounded in this way for each of the test sites, and of the 75-ft depth for the Milrow Site, are shown in Table A-2.

Table A-2

Extremes and Statistically-Derived Boundaries and Depth-Defined Boundaries of Modeled Release Zones for Radionuclides (Distances From the Groundwater Divide at Amchitka)

\begin{tabular}{|c|c|c|c|c|c|}
\hline \multirow{3}{*}{ Location } & \multicolumn{5}{|c|}{ Approximate Distance From The Shoreline (m) } \\
\hline & \multicolumn{2}{|c|}{ First Edge } & \multicolumn{2}{|c|}{ Second Edge } & \multirow{2}{*}{$\begin{array}{l}\text { 75-Foot } \\
\text { Depth }\end{array}$} \\
\hline & $\begin{array}{l}\text { Nearest } \\
\text { Edge }\end{array}$ & $\begin{array}{l}5^{\text {th }} \text { Percentile } \\
\text { Lower Bound }\end{array}$ & $\begin{array}{c}95^{\text {tht }} \text { Percentile } \\
\text { Upper Bound }\end{array}$ & $\begin{array}{l}\text { Farthest } \\
\text { Edge }\end{array}$ & \\
\hline Cannikin & 1,470 & 1,470 & 4,520 & 5,320 & NA \\
\hline Long Shot & 530 & 770 & 3,470 & 4,170 & NA \\
\hline Milrow & 240 & 260 & 3,704 & 5,740 & 2,690 \\
\hline
\end{tabular}

NA = Not applicable 


\section{A.3.2.2 Subsurface Orientation}

This section presents cross-section drawings to provide a sense of the locations in two dimensions of the test cavities and the release areas, using information from a topographic map (USGS, 1975). Figure A.2 shows a view of Amchitka with transverse lines to indicate the locations of the cross-sections described in this paragraph. Figure A.3 shows the cross-sections for Cannikin, Long Shot, and Milrow. The cross-sections provide a scaled view showing the position of the borehole and the locations of the blast cavities relative to the Pacific Ocean and Bering Sea.

\section{A.3.3 Discussion of Uncertainties}

For risk assessment modeling purposes, it was assumed that the groundwater is released from a point source between the geographic limits of locations predicted by groundwater modeling, the first and second edges. In fact, it is unlikely that a plume of material subject to subsurface dispersion as it travels for 2 to $3 \mathrm{~km}$ through the subsurface from the detonation cavities to the first edge at the sea floor (and up to $7 \mathrm{~km}$ to the second edge) will remain small enough to be considered a point source. The groundwater model predicts many potential paths that resulted from variations in model parameters. For the risk assessment model, precise knowledge about the location and nature of the release is important only for ocean dispersion modeling discussed in Section A.6.0, which states that modeling a point source is more conservative than modeling a discharge that is spread out.

\section{A.3.4 Implementation}

The $5^{\text {th }}$ percentile lower bound of first edges and the $95^{\text {th }}$ percentile upper bound of second edges at each site were used to calculate the location of the potential releases perpendicularly from the shore. The releases were assumed to occur at a point source halfway between those locations. The zone in which kelp grows was assumed to extend to $75 \mathrm{ft}$ in depth. 


\section{A.4.0 Seabed Substrates}

\section{A.4.1 Description}

Most of the seafloor around Amchitka Island has little or no sediment because it is swept bare by currents. The shallows south of the island have extensive kelp beds, which retard the current. If there is sediment, contaminants released into it may bind to the sediment, reducing their release to the sea but increasing the exposure of sediment-dwelling biota. Knowledge about the type of seabed substrate around the predicted release locations is necessary to model the subsequent transport of radionuclides and exposure of biota.

\section{A.4.2 Current Knowledge}

There are very few sand beaches on Amchitka Island. The island is bordered on the north by the Rat Island's Escarpment, where the Bering Sea floor drops rapidly to $\sim 1,500$ meters $(\mathrm{m})$. The tidal beach is typically covered with cobbles and small boulders. The south side of the island is bordered by the Aleutian Slope, which drops gradually to the oceanic trench.

A general description of the seabed by Lebednik and Palmisano (1977) states that no mud bottoms were observed in many dives to a depth of $30 \mathrm{~m}$; however, sand, gravel, and cobble bottoms do occur. In addition, there are extensive kelp beds south of the island, and kelp requires a rocky substrate. Organisms that prefer a hard, rocky bottom, such as sea urchins and sea cucumbers, are abundant around Amchitka Island, while organisms that prefer a sandy or muddy bottom, such as king crabs, are rare (Merrell, 1977). Detailed information about the seabed at the predicted locations of radionuclide releases has not been obtained, but it seems unlikely that there are extensive kelp beds. Assumptions made on the potential substrates are described below.

The possible presence of any sediment is of interest because radionuclides can adsorb to sediment particles and be removed from solution or suspension in the groundwater as it passes through to the overlying seawater. However, to ensure a conservative estimate of concentrations in seawater, the risk model does not include a factor for removal of radionuclides from water by sorption to sediment.

Lebednik and Palmisano (1977) present information that kelp is widely observed on the south side of Amchitka from near the shoreline to a depth of about $25 \mathrm{~m}$. For convenience, a depth of $75 \mathrm{ft}$ was 
used to calculate the edge of the kelp zone because the map used (USGS, 1975) has bathymetry in feet rather than meters. For risk assessment purposes, it is assumed that heavy growths of kelp on the seabed retard the flow of seawater. Kelp is assumed to be found at Milrow. To calculate exposures from the zone where kelp grows, it was assumed that all of the seabed at depths down to $75 \mathrm{ft}$ is populated by kelp, sea urchins, and other invertebrates, as well as sea otters that feed on the sea urchins. Further, in the absence of other data, it is assumed that the near-shore current is retarded by the kelp by three-fold (Jackson and Winant, 1983). The distance from the shoreline to the 75-ft depth at Milrow is shown in Table A-2.

\section{A.4.3 Discussion of Uncertainties}

The nature of the seabed around Amchitka is known (Lebednik and Palisano, 1977). What is not known, and therefore an uncertainty, is the exact nature of the seabed at the exact potential groundwater release locations. Factors that affect the risk assessment are interactions of kelp with water to retard the current and interactions between groundwater and sediment that potential radionuclides would have to pass through before being diluted in the huge volume of seawater above the ocean floor.

The retardation of the current by kelp at Amchitka is estimated from measurements in a California kelp bed. It is assumed that the kelp at Amchitka interacts the same quantitatively. Inclusion of a lower current because of kelp at Milrow resulted in a shorter and wider plume predicted by ocean dispersion modeling. However, the modeled presence of kelp (i.e., by using a lower current velocity) had no effect on the overall risk from the mean radionuclide flux (Section 5.8). The maximum risks in Scenarios 1 and 4 (mostly fish consumption, without and with kelp, respectively) are the same, as are the maximum risks in Scenarios 2 and 5 (mostly marine mammal consumption, without and with kelp, respectively) and Scenarios 3 and 6 (consumption of commercial catch, without and with kelp, respectively). Therefore, uncertainty about the effects of kelp beds on the current is not an important factor in the screening risk assessment.

It is possible that radionuclides issuing from the sea floor could pass through sediment before reaching the seawater column, and in doing so, could be bound to sediment particles. Thick sediment beds are not reported at Amchitka Island (Lebednik and Palisano, 1977), so interactions of groundwater with sediment are expected to be minimal. If sediment beds were to occur, they would decrease the concentration of radionuclides in seawater by binding the radionuclides, causing an 
overestimate of the concentrations in marine food species. Therefore, the modeled human exposure is higher when sediment is excluded than if sediment is present, and excluding sediment interactions is conservative.

\section{A.4.4 Implementation}

It is assumed that adsorption of radionuclides to sediment is negligible because there is little sediment and to ensure a conservative estimate of concentration in seawater. Extensive kelp beds, which retard the current and, thereby, reduce the dilution of released radionuclides, are assumed in one of the exposure scenarios. 


\section{A.5.0 Transport by Currents}

\section{A.5.1 Description}

Contaminants released from the seabed are moved by the ocean currents and diluted (see the discussion of dilution in the next section). The direction and extent of transport and the rate of dilution are determined by currents.

\section{A.5.2 Current Knowledge}

The following discussion addresses many details that determine the location and speed of the ocean currents. The major topics are the oceanographic setting, which greatly influences the direction and speed of the ocean currents; the pathways followed by major currents near Amchitka, and farther away in the Pacific Ocean and the Bering Sea; and the expected effect of the currents on the distribution of materials released into the water near Amchitka.

\section{A.5.2.1 Oceanographic Setting}

The Aleutian Ridge is an elongated, curved rim that rises above the seafloor, extends westward from the Bering Shelf, and separates the Pacific Ocean on the south from the Bering Sea on the north. Along the ridge are several rises above sea level that make up the Aleutian Islands (Figure 1 in the main text). Amchitka Island, one of the Rat Islands situated near the center of the Aleutian chain, is a narrow, elliptically shaped land mass oriented SSE - NNW along its major axis (Figure 1 in the main text). Amchitka Pass, the opening between Amchitka and its eastern neighbor, Amitignak Island, has a maximum depth of $1,800 \mathrm{~m}$ (Roden, 1995), which is almost 75 percent deeper than any of the passes located to the east. In contrast, Oglala Pass, which separates Amchitka from Rat Island on the west, has a shallow, 100-m bench. An additional feature distinguishing Amchitka and the Rat Islands from the rest of the Aleutians is Bowers Ridge, a northward extension of the Aleutian Ridge. Due to the region's bathymetric complexity, a number of convoluted, highly variable currents exist in the area surrounding Amchitka. 


\section{A.5.2.2 Current Pathways}

\section{Amchitka Pass}

Affecting circulation around Amchitka are two large-scale currents, Alaskan Stream and North Aleutian Ridge, that flow west on the south side and east on the north side of the Aleutian Arc, respectively (Figure A.4). Water from the upper 1,500 m of the Alaskan Stream enters Amchitka Pass with a volumetric transport of $4.1 \times 10^{6}$ cubic meters per second $\left(\mathrm{m}^{3} / \mathrm{s}\right)$. Once in the pass, currents follow a variety of trajectories, depending upon season and varying geostrophic potentials, resulting in a net contribution of $2.1 \times 10^{6} \mathrm{~m}^{3} / \mathrm{s}$ of water to eastward-flowing Bering Sea water (Reed and Stabeno, 1994). The following composite of mesoscale flow in Amchitka Pass is derived from descriptions in McAlister and Favorite (1977), Reed and Stabeno (1994), Stabeno and Reed (1994), and Okkonen (1996). Water flowing through the pass, but not directly to the Bering Sea, moves to its western side, from which it follows one of at least three possible pathways: westward to the north side of Amchitka; southward out of the pass and then west paralleling the southern shore of Amchitka; or in a large, counterclockwise eddy bounded by north- and south-flowing currents. Notably, the pattern of circulation in Amchitka Pass deviated significantly from mid-July through mid-October 1987 as net flow alternated from north to south for intervals lasting up to 3 weeks. Okkonen (1996) demonstrated that this reversal in net flow resulted from an eddy spun off the Alaskan Stream near the southern end of the pass.

\section{Pacific Coast}

There have been few measurements describing currents near the Amchitka shore. A single buoy moored to monitor tidal flows at 51 $33^{\prime} \mathrm{N} 178^{\circ} 51^{\prime} \mathrm{E}$, a point off the south shore of Amchitka, indicates a clockwise rotary current that attains an average maximum velocity of 36 centimeters per second (cm/s) (U.S. Department of Commerce, Coast and Geodetic Survey, 1995). When tidal currents on the Pacific side of Amchitka are moving westward, it is likely that flow bending around the southeastern tip of the island is drawn into the same westward path. The path of a drifter buoy tracked in 1993 (Reed and Stabeno, 1994) shows the direction of flow also can be drawn eastward, away from the southeastern coast of Amchitka (Figure A.4). During periods when the rotary current is moving in directions other than west, the water moving south from the pass may either cycle through a tidal eddy off the island's southern coast or be directly drawn eastward back into the southern arc of the gyre in Amchitka Pass. 


\section{Oglala Pass and the North Coast}

The net direction of currents in Oglala Pass is north, northeast (Stabeno and Reed, 1994), and flow from tidal currents moving along the south coast probably merge into this pathway. Data showing the direction of flow near the north coast of Amchitka are sparse. However, during winter 1968, a parachute drifter buoy and dye study tracked for only 5 hours in the "channel" north of Amchitka showed a current moving counterclockwise (McAlister et al., 1968). Based on water stratification caused by salinity, density, and temperature, Reed and Stabeno (1994) showed currents along the north side of the Aleutians, although convoluted and weak, moved to the east between $179^{\circ}$ and $171^{\circ}$ West. Therefore, it is highly likely that some water is transported to easterly moving north shore currents from the northeast bound portion of current in Oglala Pass. Prior to passing Semisopochnoi Island, the remaining northeast bound flow combines with an eastbound current (McAlister and Favorite, 1977) that either escapes north to the Bering Sea or rejoins the western arc of the gyre or circular oceanic surface current that is produced in Amchitka Pass.

\section{A.5.2.3 Particle Dispersal}

Most of the water near Amchitka Island eventually travels northward to the Bering Sea. Because the magnitude and direction of local currents are so variable, it is difficult to predict the rate of dispersal off the Aleutian Shelf for a particle located near the island. However, current velocities vary little through the water column near shore or in Amchitka Pass. Water in these areas is well mixed (Reed and Stabeno, 1994) and is not driven by density, salinity, or temperature differences; thus, flow is driven mainly by tidal currents rather than gradients in physical properties of water. For this risk assessment, it is assumed that radionuclides released near Amchitka, especially from Cannikin and Long Shot, are transported to the Bering Sea.

Measured characteristics for currents near Amchitka are shown in Table A-3, and a composite of known and likely flow trajectories is illustrated in Figure A.4.

The current velocities listed include ranges and maximum values. As a conservative estimate, the current along the north coast of Amchitka will be assumed to move at $32 \mathrm{~cm} / \mathrm{s}$ (middle of the range provided), and the current along the south coast will be assumed to move at $30 \mathrm{~cm} / \mathrm{s}$ (arbitrary reduction from $36 \mathrm{~cm} / \mathrm{s}$ ). 
Table A-3

Characteristics of Currents Affecting Flow

Near Amchitka Island

\begin{tabular}{||c||ccc||}
\hline Current & Flow $\left(\mathbf{m}^{3} / \mathbf{s}\right)$ & Velocity $(\mathbf{c m} / \mathbf{s})$ & Net Direction \\
\hline \hline Alaskan Stream & $28 \times 10^{6}$ & 40 to 65 & West \\
Amchitka Pass $^{\mathrm{a}}$ & $4.1 \times 10^{6}$ & $40 \mathrm{max}$ & North \\
North Aleutian Ridge & $20 \times 10^{6}$ & 20 to 40 & East \\
South Semisopochnoi & Not known & 25 & South, \\
North Coast & Not known & 25 to 40 & Southeast \\
Oglala Pass & Not known & 10 & East \\
South Coast & Not known & 36 & North, \\
\hline
\end{tabular}

\footnotetext{
${ }^{a}$ Net volume entering Bering Sea as a result of gyre $\sim 2.1 \times 10^{6} \mathrm{~m}^{3} \mathrm{~s}^{-1}$.

Source: Summarized from McAlister and Favorite (1977), Warren and Owens (1988), Roden (1995), Reed and Stabeno (1994), Stabeno and Reed (1994), and

U.S. Department of Commerce, Coast and Geodetic Survey (1995).
}

\section{A.5.3 Discussion of Uncertainties}

There is sufficient information about ocean currents in the vicinity of Amchitka Island to describe current patterns around the predicted locations of the groundwater releases. The risk assessment model is based on a synthesis of available knowledge, and the directions and speeds of nearshore currents have been deduced from that synthesis. General knowledge of the currents is necessary to understand the size and direction of the plumes. However, more precise knowledge of the directions and speeds of currents is likely not necessary. The risk assessment model assumes that the plumes are contained within the assumed exposure volume, which is a fishing zone defined by the $200-\mathrm{m}$ isobath, an area as much as $9 \mathrm{~km}$ to $15 \mathrm{~km}$ offshore and an area in which the predicted plumes occupy a small part. The risk assessment model is not sensitive to the precise location of each plume within the fishing zone, as long as the plume is not carried outside the fishing zone by changes in the direction or speed of the current. Given the large size of the fishing zone and the relatively small size of plume sizes, it is unlikely that variations in the direction or speed of currents would take the plumes out of the fishing zone. 


\section{A.5.4 Implementation}

The available information about near-shore currents was used to evaluate the movement of radionuclides from the release area. It was assumed that near-shore currents parallel the island shoreline and move at rates of $32 \mathrm{~cm} / \mathrm{s}$ on the north (Bering Sea) side of the island and $30 \mathrm{~cm} / \mathrm{s}$ on the south (Pacific Ocean) side. 


\section{A.6.0 Dilution Including Plume}

\section{A.6.1 Description}

Contaminants released to the seabed will be carried by currents, which typically induce turbulence as they flow. This turbulence causes contaminants to be diluted as they mix with seawater. The distances over which contaminants are distributed (and diluted) depend on the currents passing over the release locations. In turn, the mixing rate and the volume into which the radionuclides are uniformly mixed will influence the distribution of contaminants in fish and other subsistence foods. To model exposure, a plume was defined in which fish are assumed to take up radionuclides from the seawater. The boundaries of the plume define the average concentration of radionuclides because they limit the mass of radionuclides and the volume in which the radionuclides are contained. The boundaries of the plume also define the number of fish exposed to that concentration because it is assumed that the density of fish per unit area is constant (Section A.10.2.3). Thus, a larger plume, defined by a greater dilution, will expose more fish than a smaller plume, but the exposure will be to a lower concentration of radionuclides, whereas a smaller plume, defined by less dilution, will expose fewer fish to a higher concentration of radionuclides. This section describes methods to calculate steady-state concentrations of radionuclides during dilution, either near Amchitka or in the Bering Sea. An EPA mathematical model (Jirka et al., 1996c) is used to predict the plume at each location.

\section{A.6.2 Current Knowledge}

There is sufficient information about the general direction and velocity of currents at each release site and general knowledge about other modeling parameters to enable dynamic modeling of radionuclide concentrations at specific locations near Amchitka. This was performed using EPA's Cornell Mixing Zone Expert System (CORMIX) model (Section A.6.2.1), and it constituted near-shore exposure (Section A.6.2.2).

CORMIX is an EPA-approved simulation and decision support system for environmental impact assessment of mixing zones resulting from continuous point source discharges. The system emphasizes the role of boundary interaction to predict mixing behavior and plume geometry. The CORMIX methodology contains systems to model submerged single-port and multi-port diffuser discharges as well as surface discharge sources. Effluents considered may be conservative, nonconservative, heated, or they may contain suspended sediments. Advanced information systems 
provide documented water quality modeling, National Pollutant Discharge Elimination System regulatory decision support, visualization of regulatory mixing zones, and tools for outfall specification and design.

For offshore exposure, a volume representing the Aleut culture and communication area will be represented by an exposure compartment used by the Office of Naval Research (ONR) in a risk assessment for radionuclides in Arctic waters (ONR, 1997). This exposure compartment is the upper $200 \mathrm{~m}$ of the southern part of the Bering Sea, an area that is approximately the same as the Aleut culture and communication area. Each is explained in the following sections.

\section{A.6.2.1 CORMIX Model Selection and Model Description}

The following characteristics were considered before selecting the appropriate model for this study:

- The model should provide conservative predictions.

- The model should be technically sound and capable of accounting for the key factors affecting the extent (geometry) of the plume (e.g., source condition, fluid stratification, near-field processes, and far-field processes).

- The model is a public domain model and is easily available.

- The model has been extensively verified.

- The model has received adequate peer review.

- The model is easy to use.

- The model is recognized and recommended by the EPA.

Based on the above characteristics, CORMIX was selected for the present study. The CORMIX software system is a series of models for the analysis, prediction, and design of aqueous toxic or conventional pollutant discharges into diverse water bodies (e.g., the ocean currents around Amchitka Island). It represents a robust and versatile computerized methodology for predicting both the qualitative features (e.g., flow classification) and the quantitative aspects (e.g., dilution ratio, plume trajectory) of the hydrodynamic mixing processes resulting from different water and radionuclide fluxes. CORMIX can predict the extent of a plume for submerged single-point source and submerged multipoint diffuser sources. It can adapt to fluid stratification, including salinity and density. 
CORMIX can also adapt to initial and distant mixing zones. The initial mixing zone occurs near to the contaminant source, and the zone is controlled by near-field processes. The distant mixing zone occurs away from the contaminant source, and the zone is controlled by far-field processes.

CORMIX was developed under several cooperative funding agreements between EPA and Cornell University during the 1985 to 1995 time period. It is a recommended design tool in key guidance documents (EPA 1991a, EPA 1991b; Jirka 1992) on the permitting of industrial, municipal, and other nonpoint source discharges to receiving waters. CORMIX has been extensively verified by the developers through comparison of simulation results to available field and laboratory data on mixing processes (Doneker and Jirka, 1990; Akar and Jirka, 1991; Jones et al., 1996a; Jirka et al. 1996a and b). It has also undergone extensive independent peer review in journal proceedings (Doneker and Jirka, 1991; Jirka and Doneker, 1991; Jirka and Akar, 1991; Aker and Jirka, 1994; Aker and Jirka, 1995; Mendéz-Diaz and Jirka, 1996; Jones et al., 1996b; Jones and Jirka, 1996; Nash and Jirka, 1996). The EPA's established policy is to make the software freely available to all potential users through its modeling software distribution facility at the EPA Center for Environmental Assessment Modeling (CEAM) in Athens, Georgia. In addition, previous application has proven this code is highly user-interactive and offers sufficient flexibility to a modeling effort in the Bering Sea and Pacific Ocean off of Amchitka Island.

\section{A.6.2.2 Near-Shore Exposures in Plumes}

Groundwater flow through Amchitka Island eventually discharges from the seafloor into Amchitka marine waters. The groundwater modeling predicts a distribution of possible discharge locations for groundwater originating from the test cavities. A discharge location midway between the $5^{\text {th }}$ percentile lower bound and the $95^{\text {th }}$ percentile upper bound of the predicted discharges (see Table A-2) was chosen for each of the three sites, with the discharge rates set equal to a mean value estimated from the groundwater model parameters. The distribution of contaminant concentration in the water was simulated with the EPA mixing model, CORMIX (Jirka et al., 1996c), which uses a variety of hydrodynamic modules to predict mixing and advection of the discharge into a plume of contamination. As explained above, CORMIX is distributed by the EPA's CEAM and is routinely used for simulating mixing of underwater discharges with the ambient water. Output of the model varies with each module but typically consists of concentration and horizontal and vertical extent of 
the plume. These results have been used to define the spatial limits of the plume and to compute the volume of the plume and the average contaminant concentration within these limits.

Calculating exposures requires a method to convert radionuclide flux to concentration in some defined volume of seawater. That volume, called the plume, may be defined as a particular area or volume or it may be defined as a volume whose boundaries are set where the initial discharge is diluted by a certain amount. These definitions are not predetermined because no matter what they are, the model can always calculate a concentration, no matter how low, outside the boundary. For this risk assessment, the boundary was set as a dilution factor to make the plumes more consistent among sites. The size of the plume increases as the dilution factor decreases; that is, a plume defined by a $10^{-7}$ dilution is larger than a plume defined by a $10^{-6}$ dilution.

Because the concentration of radionuclides decreases as the plume size increases, there is a tradeoff between the average concentration and the size of the plume to which fish are exposed, so the concentration in fish decreases as the plume size increases. The plume size is used as a fraction of the exposure area, so the fraction of fish exposed increases as the plume size increases. For this risk assessment, a dilution factor of $10^{-7}$ was chosen. Outside the boundary, concentrations are less than one ten-millionth of the initial discharge concentration, and uptake at those concentrations are overshadowed by uptake at concentrations within the plume. Therefore, the plume boundary is judged to be sufficiently conservative.

Due to the limited knowledge of velocity, direction, and time dependence of currents at each of the three potential release locations, steady-state simulations were performed of the transport of contaminants contained in groundwater discharges. The discharges were assumed to be from a single discharge point for each simulation. A single discharge point provides a more conservative evaluation than a multi-point discharge because the initial concentration is higher with a single discharge point. Pertinent input data required for the simulations are displayed in Table A-4.

For the example model run presented here, the discharge rates chosen for each site were based on DRI estimated values. DRI has estimated that the simulated groundwater discharge rates averaged 72.5 cubic meters per day $\left(\mathrm{m}^{3} / \mathrm{d}\right)$ at Cannikin, $24.3 \mathrm{~m}^{3} / \mathrm{d}$ at Long Shot, and $24.8 \mathrm{~m}^{3} / \mathrm{d}$ at Milrow. To determine whether the CORMIX simulation outcome is sensitive to the groundwater discharge rates, CORMIX simulations with discharge rates equal to the upper and the lower 95 percent confidence 
Table A-4

Parameter Values Used in CORMIX Modeling

\begin{tabular}{|c|c|c|c|c|}
\hline Parameter & \multirow{2}{*}{ Cannikin } & \multirow{2}{*}{ Long Shot } & \multicolumn{2}{|c|}{ Milrow } \\
\cline { 3 - 5 } & & & Without Kelp & With Kelp \\
\hline \hline Water depth $(\mathrm{m})$ & 68.6 & 30.5 & 23.5 & 23.5 \\
\hline Water velocity $(\mathrm{cm} / \mathrm{s})$ & 32 & 32 & 30 & 10 \\
\hline Distance of discharge from shore $(\mathrm{m})^{\mathrm{a}}$ & 2,997 & 2,024 & 1,984 & 1,984 \\
\hline Wind speed $(\mathrm{m} / \mathrm{s})^{\mathrm{b}}$ & 8.1 & 8.1 & 8.1 & 8.1 \\
\hline Darcy-Weisbach friction factor $\mathrm{f}$ & 0.02 & 0.02 & 0.02 & 0.02 \\
\hline Water density at surface $\left(\mathrm{kg} / \mathrm{m}^{3}\right)^{\mathrm{d}}$ & 1,026 & 1,026 & 1,026 & 1,026 \\
\hline Water density at bottom $\left(\mathrm{kg} / \mathrm{m}^{3}\right)^{\mathrm{d}}$ & $1,026.1$ & $1,026.1$ & $1,026.1$ & $1,026.1$ \\
\hline Discharge rate $\left(\mathrm{m}^{3} / \mathrm{d}\right)^{\mathrm{e}}$ & 72.5 & 24.4 & 24.8 & 24.8 \\
\hline Discharge density $\left(\mathrm{kg} / \mathrm{m}^{3}\right)^{f}$ & 1,000 & 1,000 & 1,000 & 1,000 \\
\hline
\end{tabular}

${ }^{\mathrm{a}}$ CORMIX assumes a rectangular cross-section across the current, and the distance from the shore may be different from the physical distance in order to simulate interaction with a sloping bottom. Early simulations indicated that the region of the plume with a dilution of $10^{-6}$ or less would not interact with the bottom for a stratified water body.

Therefore, these distances are the physical distances to the discharge locations.

${ }^{b}$ Average wind speed computed from wind roses (Armstrong, 1977).

${ }^{\mathrm{C}}$ Darcy-Weisbach friction factor $(\mathrm{f})$, generally specified for the ambient roughness characteristics for the bounded case (Jirka et al., 1996c).

Water density at the top and bottom were estimated from temperature and salinity cross-sections (McAlister and

Favorite, 1977).

Based on a prediction for the Cannikin site by groundwater modeling.

A Assumed for cold, fresh groundwater.

$\mathrm{m}=$ Meter

$\mathrm{kg} / \mathrm{m}^{3}=$ Kilograms per meter

$\mathrm{cm} / \mathrm{s}=$ Centimeters per sec

$\mathrm{m}^{3} / \mathrm{d}=$ Cubic meters per day

$\mathrm{m} / \mathrm{s}=$ Meters per second

limits of the mean discharge rates for all the three locations (i.e., Cannikin, Long Shot, and Milrow) were performed. The confidence interval was defined as

$$
\mu \pm 1.96 \times \sigma \div \sqrt{\mathrm{n}}
$$

Where:

$\mu \quad=$ Groundwater modeling mean discharge rate

$1.96=\mathrm{t}$-statistic for 95 percent confidence interval

$\sigma \quad=$ Standard deviation of modeled discharge rates

$\mathrm{n} \quad=$ Number of times the groundwater model was run 
Based on these simulations, it was concluded the average concentration for a particular dilution scenario will not be impacted within the 95 percent confidence limit of the mean discharge rate. For example, the predicted average concentration for a $10^{-7}$ dilution scenario at Cannikin is 0.26 , with the discharge rate varying from $66.6 \mathrm{~m}^{3} / \mathrm{d}$ (lower concentration limit) to $78.4 \mathrm{~m}^{3} / \mathrm{d}$ (upper concentration limit).

All the simulations were performed for stratified conditions. In addition, the simulations of a stratified ocean were repeated with a wind speed of 3 meters per second $(\mathrm{m} / \mathrm{s})$ as a sensitivity analysis.

Output from the CORMIX model consists of three different possible descriptions of the plume. The location of the centerline of the plume is defined by longitudinal, vertical, and lateral coordinates. As the plume moves through the ocean water, a sequence of computation modules is chosen by the internal logic of CORMIX. Depending on which module in CORMIX has been used, the concentration and dimensions of the plume at each location along the axis of the plume are specified by one of the following:

1. Centerline concentration and radial distance to a concentration that is $1 / \mathrm{e}(\mathrm{e}=\mathrm{base}$ of the natural logarithms) of the centerline concentration. The plume is circular and has a Gaussian concentration distribution:

$$
C=C_{0} e^{-\left(\frac{r^{2}}{B^{2}}\right)},
$$

Where:

$\mathrm{C}_{\mathrm{o}} \quad=$ The centerline concentration

$\mathrm{r} \quad=$ Distance from the centerline

$\mathrm{B}=$ Distance to a concentration of $1 / \mathrm{e}$ of $\mathrm{C}_{\mathrm{o}}$

2. Centerline concentration, vertical dimension, and horizontal half-width to points where the concentration is 0.46 of the centerline concentration. The distribution is Gaussian in both the vertical and horizontal directions so that a boundary of constant concentration is an ellipse.

3. Vertical dimension, horizontal half-width, and average concentration over the cross-section of the plume. Numerous simulations and curve-fitting procedures allowed these results to be converted to an approximation of the form of the results in Item 2 above. 
More detailed information on the interpretation of the model output is available in the CORMIX users manual (Jirka et al., 1996c). For purposes of this assessment, the plume is defined as the region in which the concentration of radionuclides is equal to or greater than $10^{-7}$ of the concentration in the groundwater discharged into the sea. The concentration of the groundwater discharge was set at a nominal $1 \times 10^{-6}$ units so that the plume is the region enclosed by the surface on which the concentration is 0.1 (i.e., $10^{-7}$ times the starting concentration). The dimensions of the plume cross-section, the area of the cross-section within the $10^{-7}$ dilution boundary and the average concentration within that boundary, were determined at each point along the plume axis where model output was available.

The total mass of contaminant and the total volume within the plume defined by the $10^{-7}$ dilution boundary were then computed by integrating along the centerline of the plume assuming that the cross-sectional area and concentration vary linearly between adjacent cross-sections. The results of these analyses are summarized in Table A-5 and in Figures A.5 through A.8.

The effect of wind speed in stratified conditions is slight except at the Milrow site with kelp (Figure A.8). This site is shallow and the effect of kelp is modeled by reducing the velocity of the ambient water by a factor of three. Because of the slow velocity, more mixing and dilution occur over a shorter distance at a higher wind speed, and the volume of the contaminated plume is reduced. Average concentration within the $10^{-7}$ plume boundary is rather uniform, ranging from 0.264 at Cannikin to 0.27 at Long Shot and Milrow, as can be seen in Table A-5. In addition, the figures show the same behavior for the intermediate plumes defined by $10^{-6}$ and $10^{-5}$ dilution boundaries. For Milrow with kelp, because of low water velocity, the concentrations are generally higher. It may be noted that CORMIX limited prediction to $3 \times 10^{-7}$ for Milrow with kelp because the plume hits the shore at greater dilution. However, the results of risk modeling using the mean concentrations (Table A-7 and Table A-8) were the same whether or not kelp was assumed to be present.

The volume of the plume shows considerable variation with the combination of depth, current speed, wind speed, and discharge rate. For example, the volume of the plume within the $10^{-7}$ plume boundary varied from $1.34 \times 10^{7} \mathrm{~m}^{3}$ for Milrow with kelp to $1.79 \times 10^{8} \mathrm{~m}^{3}$ for Cannikin.

The figures show both longitudinal sections and plan views of the limits of the plumes defined by the $10^{-7}$ dilution boundary. 
Table A-5

Summary of Dispersion Modeling for Discharges in the Amchitka Marine Environment

\begin{tabular}{|c|c|c|c|c|c|c|c|c|}
\hline Test Site & $\begin{array}{c}\text { Discharg } \\
\text { e Rate } \\
\text { (m³/day) }\end{array}$ & $\begin{array}{l}\text { Dilution } \\
\text { Factor at } \\
\text { the Plume } \\
\text { Perimeter }\end{array}$ & $\begin{array}{c}\text { Average } \\
\text { Concentration } \\
\text { Within the } \\
\text { Plume } \\
\text { (unit) }\end{array}$ & $\begin{array}{l}\text { Mass } \\
\text { Within } \\
\text { the } \\
\text { Plume } \\
\text { (unit) }\end{array}$ & $\begin{array}{l}\text { Volume } \\
\text { Within } \\
\text { the } \\
\text { Plume } \\
\left(\mathrm{m}^{3}\right)\end{array}$ & $\begin{array}{l}\text { Plan Area } \\
\text { Within the } \\
\text { Plume } \\
\left(\mathrm{m}^{2}\right)\end{array}$ & $\begin{array}{c}\text { Mass } \\
\text { Within the } \\
\text { Plume } \\
(\%)\end{array}$ & $\begin{array}{l}\text { Downstream } \\
\text { Distance } \\
(\mathbf{k m})\end{array}$ \\
\hline \multirow{3}{*}{ Cannikin } & 72.5 & $1.0 \mathrm{E}-05$ & $1.98 \mathrm{E}+01$ & $2.35 \mathrm{E}+06$ & $1.18 \mathrm{E}+05$ & $4.20 \mathrm{E}+04$ & $3.2 \%$ & 1.9 \\
\hline & 72.5 & $1.0 \mathrm{E}-06$ & $2.50 \mathrm{E}+00$ & $1.26 \mathrm{E}+07$ & $5.02 \mathrm{E}+06$ & $1.26 \mathrm{E}+06$ & $17.2 \%$ & 8.7 \\
\hline & 72.5 & $1.0 \mathrm{E}-07$ & $2.64 \mathrm{E}-01$ & $4.72 \mathrm{E}+07$ & $1.79 \mathrm{E}+08$ & $3.28 \mathrm{E}+07$ & $64.7 \%$ & 28.3 \\
\hline \multirow{3}{*}{ Long Shot } & 24.3 & 1.0E-05 & $1.99 \mathrm{E}+01$ & $3.83 E+05$ & $1.93 \mathrm{E}+04$ & $1.17 \mathrm{E}+04$ & $1.6 \%$ & 1.3 \\
\hline & 24.3 & 1.0E-06 & $2.47 \mathrm{E}+00$ & $2.13 \mathrm{E}+06$ & $8.62 \mathrm{E}+05$ & $3.27 \mathrm{E}+05$ & $8.7 \%$ & 4.6 \\
\hline & 24.3 & $1.0 \mathrm{E}-07$ & 2.70E-01 & $8.25 \mathrm{E}+06$ & $3.05 \mathrm{E}+07$ & $7.20 \mathrm{E}+06$ & $33.8 \%$ & 15.2 \\
\hline \multirow{3}{*}{ Milrow } & 24.8 & $1.0 \mathrm{E}-05$ & $2.00 \mathrm{E}+01$ & $4.88 \mathrm{E}+05$ & $2.45 \mathrm{E}+04$ & $1.43 E+04$ & $2.0 \%$ & 1.4 \\
\hline & 24.8 & 1.0E-06 & $2.50 \mathrm{E}+00$ & $2.65 \mathrm{E}+06$ & $1.06 \mathrm{E}+06$ & $4.04 \mathrm{E}+05$ & $10.7 \%$ & 4.6 \\
\hline & 24.8 & 1.0E-07 & $2.70 \mathrm{E}-01$ & $9.29 \mathrm{E}+06$ & $3.43 \mathrm{E}+07$ & $7.94 \mathrm{E}+06$ & $37.4 \%$ & 15.4 \\
\hline \multirow{3}{*}{ Milrow with Kelp } & 24.8 & 1.0E-05 & $2.86 \mathrm{E}+01$ & $1.74 \mathrm{E}+06$ & $6.08 \mathrm{E}+04$ & $3.90 \mathrm{E}+04$ & $7.0 \%$ & 0.9 \\
\hline & 24.8 & 1.0E-06 & $2.94 \mathrm{E}+00$ & $5.91 \mathrm{E}+06$ & $2.01 \mathrm{E}+06$ & $1.02 \mathrm{E}+06$ & $23.8 \%$ & 3.7 \\
\hline & 24.8 & 3.0E-07 & 8.44E-01 & $1.13 \mathrm{E}+07$ & $1.34 \mathrm{E}+07$ & $6.17 \mathrm{E}+06$ & $45.6 \%$ & 8.1 \\
\hline
\end{tabular}


Figure A.9 shows rectangles to indicate the locations of three-dimensional (3-D) cutaway volumes. Figure A.10 shows a perspective cutaway view for Cannikin. Figure A.11 shows the same type of information for Long Shot, and Figure A.12 shows this for Milrow. In addition, Figure A.13 shows a duplicate perspective cutaway view for Milrow when kelp is assumed to retard the near-shore current by three-fold (Jackson and Winant, 1983).

To calculate the dilution of radionuclides, it is necessary to derive a dilution factor. This factor converts radionuclide flux (the rate of release of a radionuclide in $\mathrm{pCi} / \mathrm{d}$ ) to a concentration in the plume (picocuries per cubic meter $[\mathrm{pCi} / \mathrm{L}]$ ). The calculation is done by dividing the average concentration in the plume (e.g., 0.27 picocuries per cubic meter $\left[\mathrm{pCi} / \mathrm{m}^{3}\right]$ for Long Shot) by the nominal total flux $\left(1 \times 10^{6} \mathrm{pCi} / \mathrm{m}^{3} \times 24.3 \mathrm{~m}^{3} / \mathrm{d}\right)$. The result for Long Shot is $0.27 / 2.44 \times 10^{7}=1.11 \times 10^{-8} \mathrm{pCi} / \mathrm{m}^{3}$ per $\mathrm{pCi} / \mathrm{d}$ or $1.11 \times 10^{-11} \mathrm{pCi} / \mathrm{L}$ per $\mathrm{pCi} / \mathrm{d}$. Similarly, the dilution factors at the other locations are $3.6 \times 10^{-12}$ for Cannikin, $1.09 \times 10^{-11}$ for Milrow without kelp, and $3.40 \times 10^{-11}$ for Milrow with kelp.

\section{A.6.2.3 Offshore Exposure}

Offshore exposure occurs in a very large volume of water that represents the Aleut culture and communication area (Figure A.14). The information necessary to calculate concentrations in the cultural area is not available, but alternative information is available. Information used for a risk assessment by the ONR for radionuclides released into the sea by former Soviet Union naval activities (ONR, 1997) includes three compartments of various sizes in the Bering Sea. They are the northern Bering Sea (all depths), the southern Bering Sea upper layer (upper $200 \mathrm{~m}$ ), and the southern Bering Sea lower layer (deeper than $200 \mathrm{~m}$ ).

The southern Bering Sea compartments include the Aleutians, west of approximately the location of Umnak Island, and extend on the south side to Siberia midway down the Kamchatka Peninsula (about $55^{\circ} \mathrm{N}$ ) and on the north side to Siberia about $62.5^{\circ} \mathrm{N}$. They have roughly the same area as the Aleut culture and communication area (Figure A.14). Therefore, the upper layer of the southern Bering Sea compartment was used as an exposure compartment to approximate steady-state distribution of radionuclides potentially released from Amchitka undersea sources in the entire Aleut cultural and communication area. This compartment has a volume of approximately $5.5 \times 10^{17}$ liters $\left(5.5 \times 10^{14} \mathrm{~m}^{3}\right)(\mathrm{ONR}, 1997)$. 
The ONR model includes the rates at which water moves into and out of the Bering Sea compartments. There is relatively little transfer of water from the upper layer (upper $200 \mathrm{~m}$ ) to the lower layer (ONR, 1997), and much of the subsistence food, fish and mammals, and commercially important fish are found in the upper $200 \mathrm{~m}$ of the sea (Simenstad et al., 1977). Therefore, the upper Bering Sea compartment was chosen as the exposure compartment for subsistence consumers in the Aleut culture and communication area. The Bering Sea is also a widely used fishery, so the upper Bering Sea compartment was also chosen as the exposure compartment for consumers of commercial catch.

Calculating the cancer risk based on dilution of radionuclides in the offshore compartment requires calculation of the dilution factor. The steady-state concentration of radionuclides in the upper south Bering Sea compartment was calculated using a model in which an equilibrium is reached (i.e., the radionuclide flux entering the exposure compartment is equal to the radionuclide flux leaving the compartment). Fluxes of water into and out of the exposure compartment and the neighboring compartments were taken from ONR (1997). It was assumed that the radionuclide flux leaving the compartment is equal to the radionuclide concentration multiplied by the water flux leaving the compartment. On each day, the total mass of the radionuclide in the exposure compartment is equal to the total mass on the previous day, plus the radionuclide flux for one day from the releases, minus the radionuclide flux leaving the compartment on that day. That total mass is divided by the volume of the compartment to calculate the concentration. This calculation was done for many successive time periods until equilibrium was reached (i.e., the final concentration no longer changed from day to day [about 8 years]).

The concentration modeling was done by using a flux of $1 \mathrm{pCi} / \mathrm{d}$. The calculation yielded a dilution factor that can be applied for any radionuclide flux. The dilution factor was calculated to be $8.5 \times 10^{-16} \mathrm{pCi} / \mathrm{L}$ per $\mathrm{pCi} / \mathrm{d}$ of release.

\section{A.6.3 Discussion of Uncertainties}

Dilution factors are calculated for a nearshore exposure area and for an offshore exposure area. Their uncertainties are described below.

Parameters whose uncertainty affects the calculation of dilution factors for nearshore dilution include the CORMIX model, and the modeled groundwater discharge rate. Uncertainties in the CORMIX 
modeling results come from uncertainty in the input parameters. The input parameters are best scientific estimates of conditions at Amchitka, based on site-specific information about water depth, water velocity, distance of discharge from shore, wind speed, and water density.

Groundwater discharge rates were calculated by the groundwater model as mean values, so they could have higher or lower values. Variability in parameters has little effect on the outcome of the risk assessment. In particular, comparing the CORMIX modeling results using the mean groundwater discharge rate to the results using the upper and lower 95 percent confidence limits of the mean showed no effect on the concentration of radionuclides in the plume. Varying the wind speed also had little effect on the results except that under the slow current conditions at Milrow with kelp, a higher wind speed reduced the volume of the plume and, therefore, the exposure because of more rapid mixing.

The dilution factor for the nearshore exposure in plumes was calculated by dividing the concentration in the plume given by the CORMIX model by the estimated groundwater discharge rate. As stated in Section A.6.2.2, the concentration in the plume is based on scientific judgment. The groundwater discharge rate is the mean of groundwater modeling results, so the actual discharge rate could be higher or lower than the value used to calculate the dilution factor, changing the dilution factor. If the dilution factor is calculated for Cannikin, for example, by using the concentration in the plume and a range of groundwater discharge rates plus and minus one standard deviation from the mean, the result is dilution factors that are within a factor of four of the factor used. Therefore, the effect of uncertainties about the concentration in the plume and the groundwater discharge rate is expected not to be large.

The dilution factor for the offshore exposure compartment (Section A.6.2.3) was calculated with a multi-compartment model that assumed seawater flux rates into and out of ocean volumes (compartments) defined by ONR (1997). There is uncertainty that the same dilution factor applies to the Aleut culture and communication area because the ONR data are for the entire Bering Sea. Seawater flux data into and out of the Aleut culture and communication area were not available to construct a multi-compartment model specific for that area. The risks for the base case in Scenarios 7, 8, and 9 (fish subsistence diet, marine mammal subsistence diet, and commercial catch diet, respectively) are so low that an overestimate of dilution (underestimate of concentration) of one or two orders of magnitude would still predict risks far below the EPA threshold. 


\section{A.6.4 Implementation}

The various models described above were used to calculate dilution (see Table 3 in the main text) for small, near-shore plumes and large offshore volumes. Near-shore predictions depend on EPA's CORMIX model (Jirka et al., 1996c). Steady-state concentrations of radionuclides diluted in the offshore compartment were calculated from the radionuclide flux into the compartment, the volume of the compartment, and the water flux into and out of the compartment. 


\section{A.7.0 Human Receptors}

\section{A.7.1 Description}

The human receptor is the person whose exposure to radionuclides is being modeled. The receptor is assumed to be a hypothetical subsistence user who has a diet of marine animals and plants from the Bering Sea and/or Pacific Ocean near Amchitka Island, or a consumer of commercially harvested fish from the Bering Sea and/or Pacific Ocean. The receptor is assumed to be exposed for 70 years to the entire diet from the diet option chosen. Therefore, the exposure calculation includes both children and adults.

\section{A.7.2 Current Knowledge}

Subsistence users include those family and village members who hunt and fish in the Bering Sea and the Pacific Ocean waters along with those family or village members who share the catch. The model makes the conservative assumption that the immediate surroundings of Amchitka Island are used for subsistence hunting and fishing although the exact patterns of this use are undocumented to date. The receptor is exposed to any radionuclides that may be in the diet for a period of 70 years. It is unlikely that the majority of people eat exclusively a subsistence diet for an entire lifetime. By using the assumption that the receptor is a subsistence user for 70 years, the model makes a conservative estimate of exposure (that is, higher than expected to occur).

The commercial fishery in the Bering Sea and the northern Pacific Ocean provides large amounts of fish to the United States, Canada, Russia, Japan, and other countries. The receptor in this scenario is exposed to any radionuclides that may be in the diet for a period of 70 years. It is assumed that Bering Sea fish and shellfish comprise only a small fraction of the total diet of these receptors. Table A-6 provides for more information about other items in the total diet.

The exposure calculation (see Section A.13.0) assumes that the receptor is exposed to the radionuclides for a lifetime.

\section{A.7.3 Discussion of Uncertainties}

The receptors modeled as consuming a subsistence diet eating food harvested within the Aleut culture and communication area. It is not likely that subsistence fishers fish equally everywhere in that area. 
Table A-6

Subsistence Diet and Commercial Catch Diet Distribution Scenarios

for Amchitka Screening Risk Assessment

\begin{tabular}{|c|c|c|c||}
\hline \multirow{2}{*}{ Food Item } & \multicolumn{3}{|c|}{ Percent of Item in Diet } \\
\cline { 2 - 4 } & $\begin{array}{c}\text { Mainly Fish } \\
\text { Diet }\end{array}$ & $\begin{array}{c}\text { Mainly Mammal } \\
\text { Diet }\end{array}$ & $\begin{array}{c}\text { Commercial } \\
\text { Catch }\end{array}$ \\
\hline \hline Marine fish & 90 & 5 & 3.2 \\
\hline Marine mammals & 5 & 90 & 0 \\
\hline Crustaceans & 1 & 1 & 0.8 \\
\hline Mollusks & 1 & 1 & 0.4 \\
\hline Plants (including kelp) & 1 & 1 & 0 \\
\hline Other (nonmarine) foods & 2 & 2 & 95.6 \\
\hline
\end{tabular}

For example, subsistence fishers from Nikolski in the eastern Bering Sea are more likely to fish in the eastern part of the culture and communication area than to go several hundred miles to its western boundaries. However, the risk assessment model assumes that there is a fishing zone around Amchitka Island where exposed fish can be harvested. The fishing zone surrounds Amchitka and is bounded by the $200-\mathrm{m}$ isobath. It assumed to have an area of $2,000 \mathrm{~km}^{2}$ (Section A.10.2.3). The Aleut culture and communication area is approximately $1.8 \times 106 \mathrm{~km}^{2}(1,800-\mathrm{km}$ long by $1,000-\mathrm{km}$ wide). This means that the fishing zone is $2,000 / 1,800,000=0.1$ percent of the Aleut culture and communication area.

The risk assessment model also assumes that fishing is done 10 percent of the time in the fishing zone around Amchitka. The model is not sensitive to the location of fishing the other 90 percent of the time. That is, in the mathematical structure of the model it does not matter where the remaining 90 percent of fishing occurs, so the location does not have to be defined. Because not all subsistence fishers harvest fish at Amchitka, the model overstates the likely exposure of subsistence consumers and is, therefore, conservative.

The demographics of consumers of commercially caught fish are uncertain. These receptors are assumed to be distributed among the world's population, but data were not available to estimate what fraction of the population of any country or other geographic or cultural unit consumes fish caught in the Bering Sea and northern Pacific Ocean. It is important to note that the exposure calculations are 
specifically for people who eat fish harvested in the Bering Sea and northern Pacific Ocean, and many or most of any population may not eat such fish at all. Therefore, the exposure estimated for consumption of commercially caught fish is overstated for any given population.

\section{A.7.4 Implementation}

The receptors are a subsistence consumer and a consumer of commercial catch who receive a 70-year exposure to radionuclides in food. 


\section{A.8.0 Distribution of Diet}

\section{A.8.1 Description}

The dose to which consumers are exposed depends on the type and amount of contaminated food they eat. Different types of food (e.g., fish, seals, and crabs) have different BCFs; therefore, have different concentrations of radionuclides in their tissues. Therefore, the model contains a breakdown of diet. The food types considered separately are marine fish, marine mammals, crustaceans, mollusks, and plants. Other refers to nonmarine foods that would not be expected to contain radionuclides that are of marine origin. A more detailed breakdown is not appropriate because there are not different BCFs for subgroups of these food types.

\section{A.8.2 Current Knowledge}

Current information concerning diet distributions for native Alaskan communities has been published by the ONR (1997). The communities listed in that document are Emmonak, Kotzebue, Kivalina, Point Hope, Point Lay, Barrow, and Diomede. However, none of these communities is in the Aleutian chain, so these diet distributions were not used. A quote from the A/PIA trustee (2000) indicates that Aleut diets contain a large portion of marine mammals (e.g., seals). However, detailed dietary information about quantities of native marine and nonmarine foods for other populations is not available. Therefore, diets will be defined that emphasize the consumption of fish or the consumption of marine mammals as the major sources of food.

The value that is used for daily food consumption by subsistence consumers was taken from the Community Profile Database (ADFG, 2002). The average daily consumption rate used in the risk model $(1.25 \mathrm{~kg} / \mathrm{d})$ is the $95^{\text {th }}$ percentile upper bound estimate of per capita consumption for the community of Nikolski, Alaska (ADFG, 2002). This is the highest consumption rate among several communities (Akutan, Atka, False Pass, Nikolski, St. Paul, and Unalaska) listed in the database. The mean reported per capita consumption for these communities for what is designated in the database as the most representative year is $0.53 \mathrm{~kg} / \mathrm{d}$, and the mean consumption rates of fish and marine mammals are $0.28 \mathrm{~kg} / \mathrm{d}$ and $0.12 \mathrm{~kg} / \mathrm{d}$, respectively. For comparison, annual consumption rates of food from marine sources were reported for Arctic Seas communities (ONR, 1997). The mean consumption rate was $0.71 \mathrm{~kg} / \mathrm{d}$, and the mean consumption rates of fish and marine mammals were 
$0.16 \mathrm{~kg} / \mathrm{d}$ and $0.48 \mathrm{~kg} / \mathrm{d}$, respectively. Therefore, the consumption rates used in the model $(1.25 \mathrm{~kg} / \mathrm{d}$ total and a maximum of $1.125 \mathrm{~kg} / \mathrm{d}$ fish and marine mammals) are conservative.

Consumers of commercial catch are assumed to eat 0.86 kilograms $(\mathrm{kg})$ of food daily, which is presented in the EPA Exposure Factors Handbook (EPA, 1997). The modeled consumption rate for commercially caught fish is $0.0275 \mathrm{~kg} / \mathrm{d}$, a value between the mean (approximately $0.015 \mathrm{~kg} / \mathrm{d}$ ) and the $95^{\text {th }}$ percentile upper confidence limit (between 0.040 and $\left.0.045 \mathrm{~kg} / \mathrm{d}\right)(\mathrm{EPA}, 1997)$ for the general U.S. population. Therefore, fish consumption rates for the modeled consumers of commercially caught fish are also conservative. The diet distributions are presented in Table A-6.

\section{A.8.3 Discussion of Uncertainties}

There is uncertainty in the exact distribution of foods of marine origin in the receptors' diets. The risk results (Section 5.8) show that the scenario in which marine fish make up 95 percent of the diet gave the highest exposure, suggesting that the quantity of fish consumed is the most sensitive diet variable. The distribution of fish and marine mammals in the diets of the six A/PIA communities used for reference (ADFG, 2000b) ranged from 40.5 percent to 69 percent fish and 5 percent to 48 percent marine mammals, but in the screening risk assessment the consumption rates are assumed to be 95 percent fish in the fish subsistence diet and 95 percent marine mammals in the marine mammal subsistence diet. Land mammals accounted for 3 percent to 27 percent of the diet, but in the screening risk assessment they are included in the 2 percent "Other (non-marine) foods" category (Table A-6). Therefore, the risk assessment model's assumption that 95 percent of the diet consists of fish or marine mammals is conservative.

The daily consumption rate and diet distributions used in the model are higher than the mean consumption rate and upper bound of the distributions reported for the six reference communities in the A/PIA database by three-fold or more in the scenarios with 95 percent fish consumption (maximum risk of $9.7 \times 10^{-11}$ for mean discharge) and four-fold or more in the scenarios with 95 percent marine mammal consumption (maximum risk of $5.3 \times 10^{-11}$ for mean discharge).

The rate of fish consumption in the scenarios for consumption of commercial catch is also conservative. The value, 3.4 percent of $0.86 \mathrm{~kg}$ per day, is approximately $27.5 \mathrm{~g} / \mathrm{day}$. This is nearly double EPA's reported value of approximately $14 \mathrm{~g} /$ day $(E P A, 1997)$ for the average rate of fish consumption by the general population. In addition, it is unlikely that any population consuming 
commercially caught fish gets all of its fish from the Bering Sea and northern Pacific Ocean (Scenario 9), and certainly not from the zone immediately surrounding Amchitka Island (Scenarios 3 and 6). Therefore, the risk assessment model overestimates the risk from consumption of commercial catch for the mean discharge rates or base case $\left(4.2 \times 10^{-11}\right)$ by many-fold.

\section{A.8.4 Implementation}

This risk assessment conservatively assumed one diet that was high in fish and one diet that was high in marine mammals, as denoted in Table A-6. This assumption resulted in an overestimate of exposure when it is compared to dietary distributions for Aleuts and quantities of native marine foods eaten by the native Alaskan consumers in Aleutian communities as shown in the A/PIA Community Profile Database (ADFG, 2002). For consumers of commercial catch, the diet is assumed to be mainly of nonmarine origin. The dietary fraction was used in the calculation of the radionuclide risk factor (see Table 1 in the main text). 


\section{A.9.0 Bioconcentration Factors}

\section{A.9.1 Description}

Substances are taken up from water by marine biota, both directly and through the food web. The $\mathrm{BCF}$ is the ratio of concentration of a substance in receptor tissue to the concentration in the exposure medium (e.g., water, sediment). As used here, BCF includes uptake from food, so it is a composite of uptake factors from all sources of exposure and especially marine water.

\section{A.9.2 Current Knowledge}

Substances in water may be concentrated as they are taken up by primary producers and transferred up the food web to the top-level predators. At each step in the food web, a substance may be further concentrated or the predator may exclude the substance to various degrees. Therefore, it is useful to have BCFs for each trophic level in the food web.

Published data are available for concentrations of some elements in marine fish and seawater near Amchitka Island (Bloom et al., 1975; Isaakson and Seymour, 1968). These data have been used to calculate BCFs for fish species for some radionuclides (IT, 1999), and are used preferentially herein as long as the element was detected in both fish flesh and water. Some BCFs (i.e., for strontium-90, cesium-137, plutonium-239, plutonium-240, and plutonium-241) come from measurements of radionuclide concentrations in water and marine mammal tissue in arctic waters (ONR, 1997). These values were used in preference to published values for biota from other waters. BCFs have also been published by the International Atomic Energy Agency (IAEA) (1985). The IAEA data include BCFs for fish, crustaceans, mollusks, and macroalgae. Tabulated data for uptake of most of the ROPCs for this risk assessment by crustaceans, mollusks, and macroalgae were not found in other sources. All BCFs for nonmammals were derived either by direct measurement of contaminant concentrations in biota and water or by estimates of uptake based on the uptake of chemicals with similar chemical properties. Note that food preparation is assumed to be absent. Therefore, there is no allowance for selective consumption of body parts that may have higher or lower BCFs than those for flesh.

The BCFs for mammals were derived using EPA guidance (EPA, 1999). EPA presents a method to calculate the concentration of chemicals in the flesh of an animal from the concentration in food. The EPA method (EPA, 1999) states that the BCF for a mammal ( $\mathrm{kg}$ food/kg flesh) is computed by 
multiplying the uptake factor for beef ( $\mathrm{Ba}, \mathrm{mg} / \mathrm{kg}$ flesh per $\mathrm{mg}$ ingested/d) by the food ingestion rate $(\mathrm{IR}, \mathrm{kg}$ food/d): $\mathrm{BCF}=\mathrm{Ba} \times \mathrm{IR}$. Published uptake factors for each radionuclide (Baes et al., 1984) were first adjusted for mammal receptors represented by sea lions by multiplying the uptake factors by the daily food ingestion rate of the receptor (EPA, 1999). For sea lions, the food consumption rate was calculated by using allometric equations provided by the EPA (1993) for placental mammals. The estimated energy requirement for a sea lion or other mammal weighing $566 \mathrm{~kg}$ (ADFG, 2000b) was estimated to be 38,030 kilocalories per day (kcal/d). This value was divided by the energy content of fish (1.2 kilocalories per gram) to yield the ingestion rate of $31.7 \mathrm{~kg} / \mathrm{d}$. This value is a more conservative estimate than a published estimate of up to 3 percent of body weight (ADFG, 2000b), which would be $17.0 \mathrm{~kg} / \mathrm{d}$. The result of these calculations was the ratio of contaminant concentration in flesh to the average concentration in the diet (pCi/g flesh per pCi/g food). The ratio was then multiplied by the $\mathrm{BCF}$ for fish ( $\mathrm{pCi} / \mathrm{g}$ food per $\mathrm{pCi} / \mathrm{L})$ to derive a water-to-flesh $\mathrm{BCF}$ (pCi/g flesh per $\mathrm{pCi} / \mathrm{L})$.

The BCFs chosen for this risk assessment are presented in Table A-7.

\section{A.9.3 Discussion of Uncertainties}

The BCFs for some radionuclides (Table A-7) were calculated from the reported concentrations of elements in marine biota found in Amchitka waters (Bloom et al., 1975; Isaakson and Seymour, 1968). There is a wide variability among different samples for the same element. This is probably partly because of individual variations in exposure and age and partly because concentrations in the flesh of biota and in seawater were so low that analytical error would have introduced a large uncertainty in the ratio. Most elements comprising the chosen radionuclides had BCFs that varied by a factor of 10 to 100 in different samples. When multiple data were presented, the highest was chosen. For example, Bloom et al. (1975) and Isaakson and Seymour (1968) observed strontium concentrations that led to BCFs from 0.01 to 0.93 . The BCF used in the risk assessment model is the most conservative, 0.93. Therefore, BCFs are assumed to overstate the average concentration of most radionuclides in fish tissue.

When no Amchitka data were available, BCFs were the recommended numbers published by IAEA (1985). These were values calculated from observed concentrations in marine biota, but not from the Amchitka vicinity. The IAEA values (Table A-7) are intermediate values chosen by IAEA as the best values from observations that ranged over factors of about 5-fold to as much as 400-fold. 
The exposure by ingestion of marine mammals is calculated by using an uptake model (EPA, 1999) for transfer of radionuclides from food to predator tissues. The model includes the rate of food ingestion by the marine predator, which was calculated for Steller sea lions weighing $566 \mathrm{~kg}$ $(1,245 \mathrm{lb})$. The resulting food consumption rate was $31 \mathrm{~kg} / \mathrm{d}$. This value was used rather than a less conservative alternative value, which is an estimate of 3 percent of body weight, or $17 \mathrm{~kg} / \mathrm{d}$, from ADFG (2000b). If the ADFG estimate is more accurate than the number calculated by the EPA method, the BCFs for marine mammals would be slightly over half the BCFs that were used. Therefore, the risk assessment model may overstate the BCF for marine mammals by nearly two-fold on the basis of the food consumption rate.

\section{A.9.4 Implementation}

The BCFs presented in Table A-7 were used along with dietary distributions and dilution factors to calculate dietary concentration factors for radionuclides in seawater (see Table 3 in the main text). The dietary concentration factor was multiplied by conversion factors to convert it to the lifetime ingestion exposure factor (see Table 4 in the main text). 
Table A-7

Bioconcentration Factors for Radionuclides by Biota Representing Groups of Food Sources for Subsistence Consumers and Commercial Catch Consumers Near Amchitka Island

\begin{tabular}{|c|c|c|c|c|c|c|c|c|c|c|}
\hline Radionuclide & $\begin{array}{l}\text { BCF for } \\
\text { Fish } \\
(\mathrm{L} / \mathrm{kg})\end{array}$ & Source & $\begin{array}{l}\text { BCF for Marine } \\
\text { Mammals } \\
(\mathrm{L} / \mathbf{k g})\end{array}$ & Source & $\begin{array}{c}\text { BCF for } \\
\text { Crustaceans } \\
(\mathrm{L} / \mathrm{kg})\end{array}$ & Source & $\begin{array}{l}\text { BCF for } \\
\text { Molluscs } \\
(\mathrm{L} / \mathrm{kg})\end{array}$ & Source & $\begin{array}{l}\text { BCF for } \\
\text { Plants } \\
(\mathrm{L} / \mathrm{kg})\end{array}$ & Source \\
\hline Tritium & $1.00 \mathrm{E}+00$ & $\mathrm{~A}$ & $1.00 \mathrm{E}+00$ & $\mathrm{D}$ & $1.00 \mathrm{E}+00$ & $A$ & $1.00 \mathrm{E}+00$ & $\mathrm{~A}$ & $1.00 \mathrm{E}+00$ & $\mathrm{~A}$ \\
\hline Carbon-14 & $1.79 \mathrm{E}+04$ & $A$ & $1.00 \mathrm{E}+00$ & $\mathrm{D}$ & $2.00 E+04$ & $A$ & $5.00 \mathrm{E}+04$ & $A$ & $1.00 \mathrm{E}+04$ & $A$ \\
\hline Chlorine-36 & $3.60 \mathrm{E}-01$ & $\mathrm{~B}$ & $9.13 \mathrm{E}-01$ & $\mathrm{D}$ & $5.00 \mathrm{E}-02$ & $A$ & $1.00 \mathrm{E}+00$ & $A$ & $5.00 \mathrm{E}-02$ & $A$ \\
\hline Strontium-90 & $9.26 \mathrm{E}-01$ & $\mathrm{C}$ & $1.00 \mathrm{E}+00$ & $E$ & $2.00 \mathrm{E}+00$ & $A$ & $1.00 \mathrm{E}+01$ & $A$ & $5.00 \mathrm{E}+00$ & $\mathrm{~A}$ \\
\hline Yttrium-90 & $2.00 \mathrm{E}+01$ & $A$ & $1.90 \mathrm{E}-01$ & $\mathrm{D}$ & $1.00 \mathrm{E}+03$ & $A$ & $1.00 \mathrm{E}+03$ & $A$ & $1.00 \mathrm{E}+03$ & $A$ \\
\hline Technetium-99 & $3.00 \mathrm{E}+01$ & A & $8.08 \mathrm{E}+00$ & $\mathrm{D}$ & $1.00 \mathrm{E}+03$ & A & $1.00 \mathrm{E}+03$ & A & $1.00 \mathrm{E}+03$ & A \\
\hline lodine-129 & $1.00 \mathrm{E}+01$ & $\mathrm{~A}$ & $2.22 \mathrm{E}+00$ & $\mathrm{D}$ & $1.00 \mathrm{E}+01$ & $\mathrm{~A}$ & $1.00 \mathrm{E}+01$ & $\bar{A}$ & $1.00 \mathrm{E}+03$ & $\bar{A}$ \\
\hline Cesium-137 & $1.00 \mathrm{E}+02$ & A & $1.00 \mathrm{E}+02$ & $E$ & $3.00 \mathrm{E}+01$ & $\bar{A}$ & $3.00 \mathrm{E}+01$ & $\bar{A}$ & $5.00 \mathrm{E}+01$ & $\bar{A}$ \\
\hline Samarium-151 & $5.00 \mathrm{E}+02$ & A & $7.92 \mathrm{E}+01$ & $\mathrm{D}$ & $1.00 \mathrm{E}+03$ & A & $5.00 \mathrm{E}+03$ & A & $3.00 \mathrm{E}+03$ & A \\
\hline Europium-152 & $3.00 \mathrm{E}+02$ & $A$ & $4.75 \mathrm{E}+01$ & $\mathrm{D}$ & $1.00 \mathrm{E}+03$ & $A$ & $7.00 \mathrm{E}+03$ & $A$ & $3.00 \mathrm{E}+03$ & A \\
\hline Gadolinium-152 & $5.00 \mathrm{E}+02$ & $A$ & $5.55 \mathrm{E}+01$ & $\mathrm{D}$ & $2.00 E+03$ & $A$ & $5.00 \mathrm{E}+03$ & $A$ & $3.00 \mathrm{E}+03$ & $A$ \\
\hline Uranium-234 & $1.00 \mathrm{E}+00$ & A & 6.34E-03 & $\mathrm{D}$ & $1.00 \mathrm{E}+01$ & A & $3.00 \mathrm{E}+01$ & A & $1.00 \mathrm{E}+02$ & A \\
\hline Uranium-236 & $1.00 \mathrm{E}+00$ & $A$ & $6.34 \mathrm{E}-03$ & $\mathrm{D}$ & $1.00 \mathrm{E}+01$ & $\mathrm{~A}$ & $3.00 \mathrm{E}+01$ & $A$ & $1.00 \mathrm{E}+02$ & $A$ \\
\hline Uranium-238 & $1.00 \mathrm{E}+00$ & A & 6.34E-03 & $\mathrm{D}$ & $1.00 \mathrm{E}+01$ & $A$ & $3.00 \mathrm{E}+01$ & A & $1.00 \mathrm{E}+02$ & A \\
\hline Neptunium-237 & $1.00 \mathrm{E}+01$ & A & $1.74 \mathrm{E}-02$ & $D$ & $1.00 \mathrm{E}+02$ & A & $4.00 \mathrm{E}+02$ & A & $5.00 \mathrm{E}+01$ & A \\
\hline Plutonium-239 & $4.00 \mathrm{E}+01$ & A & $3.00 \mathrm{E}+00$ & $E$ & $3.00 \mathrm{E}+02$ & A & $3.00 \mathrm{E}+03$ & A & $2.00 \mathrm{E}+03$ & A \\
\hline Plutonium-240 & $4.00 \mathrm{E}+01$ & A & $3.00 \mathrm{E}+00$ & $E$ & $3.00 \mathrm{E}+02$ & A & $3.00 \mathrm{E}+03$ & A & $2.00 \mathrm{E}+03$ & A \\
\hline Plutonium-241 & $4.00 \mathrm{E}+01$ & A & $3.00 \mathrm{E}+00$ & $E$ & $3.00 \mathrm{E}+02$ & A & $3.00 \mathrm{E}+03$ & A & $2.00 \mathrm{E}+03$ & $A$ \\
\hline Americium-241 & $5.00 \mathrm{E}+01$ & $A$ & $5.55 E-03$ & $\mathrm{D}$ & $5.00 \mathrm{E}+02$ & $A$ & $2.00 E+04$ & $A$ & $8.00 \mathrm{E}+03$ & $A$ \\
\hline
\end{tabular}

$A=$ IAEA (1985)

$\mathrm{B}=$ Bloom et al. (1975)

C $=$ Isaakson and Seymour (1968)

$\mathrm{D}=$ Uptake factors from Baes et al. (1984), multiplied by daily food ingestion rate (31.7 kg/d for marine mammals, represented by sea lions), as specified by EPA (1999). Those

products are multiplied by the BCFs for fish (consumed by marine mammals).

$\mathrm{E}=$ ONR (1997) 


\section{A.10.0 Fraction of Contaminated Diet}

\section{A.10.1 Description}

Organisms near areas of potential release could be exposed to contaminants. Exposure and bioaccumulation depend on movement of an organism in space and time. This, in turn, is related to migration between feeding and reproductive habitats. Knowledge of these movement patterns provided information of the fractions of contaminated organisms ingested by consumers.

\section{A.10.2 Current Knowledge}

The following discusses the distribution and abundance of several fish species and Steller sea lions in the vicinity of Amchitka Island. Annual population or biomass estimates for groundfish (fishes in the commercial fishery other than halibut or salmon) are generated from commercial fisheries and research vessel data from defined, bounded reporting areas (Figure A.15). The bounds of reporting areas encompassing Amchitka vary with the type of fishery and agency monitoring it. The National Marine Fisheries Service (NMFS) establishes boundaries for groundfish and invertebrates and censuses marine mammal populations. The International Pacific Halibut Commission (IPHC) and North Pacific Anadramous Fish Commission, respectively, designate reporting areas for Pacific halibut and monitor salmon fisheries. These two agencies also share information with NMFS divisions to assess the size of halibut and salmon stocks.

Because many organisms inhabit specific depth ranges or distances from shore, abundance by area is predicted by reducing population estimates from whole reporting areas to cover only portions of the ocean where organisms are known to occur. The actual distribution of organisms in natural environments is patchy and variable, corresponding to the distribution of prey resources and reproductive habitats. However, to predict the number and mass of organisms occurring during a year in specific locations near Amchitka, populations are modeled as evenly dispersed. Abundance, mass, and life expectancy estimates for selected fishes and the Steller sea lions are discussed in Section A.10.2.1 and Section A.10.2.2 and are summarized in Table A-8. 
Table A-8

Summary of Abundance, Biomass, and Life Expectancy Estimates for Species Inhabiting Areas Near the Amchitka Coast

\begin{tabular}{||c|c|c|c||}
\hline Species & Abundance & Biomass & $\begin{array}{c}\text { Life Expectancy } \\
\text { (years) }\end{array}$ \\
\hline \hline Pacific halibut & $101 / \mathrm{km}^{2}$ & $376 \mathrm{~kg} / \mathrm{km}^{2}$ & 40 \\
\hline Atka mackerel & $4,643 / \mathrm{km}^{2}$ & $6,500 \mathrm{~kg} / \mathrm{km}^{2}$ & 15 \\
\hline Pacific ocean perch & $365 / \mathrm{km}^{2}$ & $380 \mathrm{~kg} / \mathrm{km}^{2}$ & 30 \\
\hline Walleye pollock & $143 / \mathrm{km}^{2}$ & $110 \mathrm{~kg} / \mathrm{km}^{2}$ & 15 \\
\hline $\begin{array}{c}\text { Pink, chum, and } \\
\text { sockeye salmon }\end{array}$ & $252 / \mathrm{km}^{2}$ & $974 \mathrm{~kg} / \mathrm{km}^{2}$ & 6 \\
\hline Dolly varden & $110 / \mathrm{km}^{2}$ & $55 \mathrm{~kg} / \mathrm{km}^{2}$ & 6 \\
\hline Steller sea lion & $0.065 / \mathrm{km}^{2}$ & $20 \mathrm{~kg} / \mathrm{km}^{2}$ & 20 \\
\hline
\end{tabular}

$\mathrm{km}^{2}=$ Square kilometers

$\mathrm{kg} / \mathrm{km}^{2}=$ Kilograms per square kilometer

\section{A.10.2.1 Marine Fish}

\section{Pacific Halibut, Hippoglossus stenolepis}

Pacific halibut biology discussed below follows that provided by the IPHC (1998). The Pacific halibut is one of the largest teleost (bony) fishes in the world, attaining lengths as great as $9 \mathrm{ft}(2.7 \mathrm{~m})$. Adults tend to remain on the same feeding grounds, year after year, at depths ranging between 25 and $275 \mathrm{~m}$. Spawning occurs at greater depths (185 to $455 \mathrm{~m})$ on the edge of the continental shelf. By the time they are 8-years old, a majority of males are sexually mature, whereas females do not mature until reaching an average age of 12 years. Eggs and larvae are denser than surface water and drift with deep ocean currents. As larvae grow, they move upward through the water column and by six months postlarval young settle on the bottom, occupying shallow habitats between the surface and $60 \mathrm{~m}$. The maximum recorded age of Pacific halibut is 55 years for a male and 42 years for a female (IPHC, 2000). Therefore, it is reasonable to assume that halibut generations are depleted by a maximum of 40 years.

The IPHC used NMFS trawl data to estimate Pacific halibut abundance from Area 4B (Figure A.15), the reporting area that encompasses Amchitka Island (Hoag et al., 1997). As with estimates for groundfish populations, IPHC inferences about abundance are made from samples within the area reduced to include only the depth strata halibut are known to occupy. The Pacific halibut abundance 
estimate based on 1991 trawl data in Area 4B was 4,176,623 fish per 51,571 $\mathrm{km}^{2}$ of sampled area (Clark et al., 1997). If halibut were evenly dispersed, they were at a density of $81 \mathrm{fish} / \mathrm{km}^{2}$. The IPHC notes estimates are relative to sampling effort and are not measures of total halibut present in the reporting area (i.e., they calculate abundance as the mean number of fish captured in trawl nets per total area swept). In addition, they note that trawl gear cannot cover areas of very rough bottom that are preferred by halibut and are prevalent in the Aleutians west of $170^{\circ} \mathrm{W}$ longitude. A conservative estimate of Pacific halibut abundance in the waters surrounding Amchitka is generated by assuming that trawl gear detects only a portion of the actual population. For example, assuming 25 percent of individuals avoided capture during sampling runs results in an estimate of the total number of halibut. The number caught combined with the number missed is shown in the following calculation: 81 halibut $/ \mathrm{km}^{2}+0.25 \times 81$ halibut $/ \mathrm{km}^{2}=101$ halibut $/ \mathrm{km}^{2}$.

Biomass estimates for Area 4B are reported only for the exploitable portion of the halibut population, which IPHC designates as age 8 years and greater $(8+)$. The biomass estimate for age $8+$ halibut is $15,921,360 \mathrm{~kg}$. The distribution of abundance by age is not available for the immature portion of the population, so it is arbitrarily assumed that two-thirds of halibut in Area 4B are younger than 8-years old. In 1999, 19,000,000 halibut in the Bering Sea population that were less than $65 \mathrm{~cm}$ long weighed $19,000,000 \mathrm{~kg}$, equal to $1 \mathrm{~kg} /$ young halibut. Assuming again that trawls missed 25 percent of halibut in Area 4B, a total of 5,220,778 halibut were present $(4,176,623$ halibut $\times 0.25+4,176,623$ halibut $=5,220,778$ halibut). Multiplying two-thirds by the total halibut yields 3,480,518 individuals in the immature segment of the population. Summing the estimated weight of the mature segment of the population and the estimated weight of the immature halibut gives a total halibut weight estimate of $19,401,878 \mathrm{~kg}$. Dividing this weight by the surface area sampled provides a biomass estimate of $376 \mathrm{~kg}$ halibut $/ \mathrm{km}^{2}$.

\section{Atka Mackerel, Pleurogrammus monopterygius}

The demographics of Atka mackerel are described in Fritz and Lowe (1998). An abundant member of the epipelagic (open water near the surface) community along the Aleutian Islands, Atka mackerel travel in dense schools at depths ranging from the surface to $200 \mathrm{~m}$. During the summer months, they move to in-shore demersal (bottom) habitats to spawn. In the fishery off the south coast of Amchitka, the ratio of females to males increases between May and August, indicating the duration of the spawning period. Hatched larvae are pelagic and are dispersed with currents. Although their early 
life history is not known, it is assumed that young Atka mackerel remain away from the coast until they return to the fishery as reproductive adults after an average of 3 years. No Atka mackerel over 15-years old were present in Aleutian Island catches in year 2000 (Lowe and Fritz, 2000). Therefore, 15 years is likely the maximum life expectancy of Atka mackerel.

Amchitka populations of Atka mackerel are within NMFS statistical reporting Area 542

(Figure A.15). In this reporting area, the NMFS estimate of adult Atka mackerel biomass was 330,255 metric tons in year 2000 (Lowe and Fritz, 2000). The ocean surface of Area 542 calculated by SAIC from the National Oceanographic and Atmospheric Administration's (NOAA) (1976) navigation chart, Bering Sea (Southern Part), is approximately 300,000 km². In 1997, 80 percent of the Atka mackerel catch in the Aleutian Islands was within Steller sea lion critical habitat, the surface area of which is 40,587 $\mathrm{km}^{2}$ in Section 542 (NMFS, 2000). Assuming 80 percent of the Atka mackerel population was evenly dispersed in sea lion-critical habitat in a year, there is a density of 6.5 metric tons $(\mathrm{mT})(6,500 \mathrm{~kg})$ of fish $/ \mathrm{km}^{2}$ of ocean surface for the year 2000 population $\left(330,255 \mathrm{mT} \times 0.80=264,204 \mathrm{mT}\right.$ and $264,204 \mathrm{mT} / 40,587 \mathrm{~km}^{2}=6.5$ metric tons per square kilometers $\left.\left[\mathrm{mT} / \mathrm{km}^{2}\right]\right)$.

The most frequently occurring length class of Atka mackerel captured off the coast of Amchitka was 35 to $40 \mathrm{~cm}$ (Fritz and Lowe, 1998). Information on the length-weight relationship was not provided, so it is assumed that the weight of an average-sized adult Atka mackerel is $1.4 \mathrm{~kg}$ ( 3 pounds). Dividing the biomass estimate by the average weight per fish $\left(6500 \mathrm{~kg} / \mathrm{km}^{2} / 1.4 \mathrm{~kg}\right)$ yields an abundance estimate of 4,643 Atka mackerel/ $\mathrm{km}^{2}$.

\section{Pacific Ocean Perch, Sebastes alutus}

Pacific Ocean perch inhabit outer continental shelf and upper slope regions, mainly at depths from 100 to $400 \mathrm{~m}$ (Witherell, 2000). Spencer et al. (2000) indicate Pacific Ocean perch are most concentrated between 200 and $800 \mathrm{~m}$ because this is the depth range where fishing vessels apply most of their effort. Females are viviparous, giving birth to swimming larvae. Pacific Ocean perch have a long life span, with a recorded maximum age of 90 years. Biomass and abundance data are reported only for year classes up to age 25 . Therefore, it is assumed that a majority of each Pacific Ocean generation expires by the end of 30 years. 
Biomass and numbers of Pacific Ocean perch inhabiting Aleutian Islands reporting areas

(Figure A.15) have been estimated (Spencer et al., 2000). Biomass estimates are reported separately for Areas 541, 542, and 543, but abundance (number of fish) estimates are given only for the three areas combined. The Area 42 biomass estimate for year 2000 was 114,319 mT, accounting for approximately 25 percent of the total Pacific Ocean perch biomass in the three reporting areas. The total number of Pacific Ocean perch in the three areas combined was 437,805,000.

If the spatial distribution of weight classes is representative of the spatial distribution of perch abundance, then 25 percent, or 109,451,250 individuals, in the Aleutian Island Pacific Ocean perch population inhabit Area $542(0.25 \times 437,805,000$ perch $=109,451,250$ perch $)$. Dividing the number of perch by the surface area of Area 542 yields 365 Pacific Ocean perch $/ \mathrm{km}^{2}$ (109,451,250 perch/ $300,000 \mathrm{~km}^{2}=365$ perch $\left.\mathrm{km}^{2}\right)$. The biomass estimate is $0.38 \mathrm{mT}(380 \mathrm{~kg})$ of Pacific Ocean perch $/ \mathrm{km}^{2}\left(114,319 \mathrm{mT} / 300,000 \mathrm{~km}^{2}=0.38 \mathrm{mT} / \mathrm{km}^{2}\right)$.

\section{Walleye Pollock, Theragra chalcogramma}

Although walleye pollock are a specific target of some commercial fisheries operations in the Aleutian Islands, most research has focused on populations in the Bering Sea. Because fishery assessments indicate that Aleutian Islands and Bering Sea populations likely belong to a single stock (Ianelli et al., 2000), it is reasonable to assume that the biology of walleye pollock in the Aleutians is similar to that in the Bering Sea.

Aspects of walleye pollock biology are discussed in Witherell (2000). Walleye pollock are the most abundant groundfish in the Bering Sea and Aleutian Islands fisheries. They become mature (reproductive) between the ages of 4 and 5 years. In April, they migrate to shallow (90 to $140 \mathrm{~m}$ ) spawning grounds from deeper $(400 \mathrm{~m})$ continental shelf regions. A single female walleye pollock produces 60,000 to 400,000 eggs, which are released in the water column where they are suspended and then transported by currents. Age-specific information for pollock is reported for generations up to 15 years old, so it is assumed that the life expectancy of most walleye pollock does not exceed 15 years.

Estimates of walleye pollock biomass are reported only from Areas 541, 542, and 543 combined. The year 2000 estimate for these areas is 105,554 $\mathrm{mT}$ (Ianelli et al., 2000). Distributing this biomass evenly throughout the three Aleutian Islands reporting areas, which together occupy a surface area of 
$1,001,780 \mathrm{~km}^{2}$, results in an estimate of $0.11 \mathrm{mT}(110 \mathrm{~kg})$ of pollock $/ \mathrm{km}^{2}$

$\left(105,554 \mathrm{mT} / 1,001,780 \mathrm{~km}^{2}=0.11 \mathrm{mT} / \mathrm{km}^{2}\right)$.

Average weights of different year classes (generations separated by one year) of walleye pollock are reported from Bering Sea populations (Ianelli et al., 2000). Although abundance by age shifts from year to year, a majority of the catch consists of 3- to 8-year old pollock. The average weight of a pollock from year classes 3 to 8 is $0.67 \mathrm{~kg}$. For 9- to 15 -year old pollock, it is $1.4 \mathrm{~kg}$. Assuming a population of pollock where 75 percent are age 3 to 8 and 25 percent are age 9 to 15 , and coupling this assumption with the biomass estimate of $0.11 \mathrm{mT} / \mathrm{km}^{2}$, the abundance estimate is 143 walleye pollock $/ \mathrm{km}^{2}$ (i.e., $\left.[0.75 \times 110 \mathrm{~kg} / 0.67 \mathrm{~kg}]+[0.25 \times 110 \mathrm{~kg} / 1.4 \mathrm{~kg}]=142.7\right)$.

\section{Salmonidae, Salmon and Trout}

Four salmonids, pink salmon (Oncorhynchus gorbuscha), sockeye salmon (Oncorhynchus nerka), chum salmon (Oncorhynchus keta), and dolly varden trout (Salvelinus malma), inhabit areas off the coast of Amchitka. After hatching in freshwater streams, pink (Hard et al., 1996) and chum salmon (Johnson et al. 1997) migrate almost immediately to the marine environment. Juveniles remain near shore or in estuaries, where they grow rapidly. After several weeks to a few months, both species move farther offshore. Pink salmon reach maturity at 2 years, and chum salmon mature, on average, after 4 years. Sockeye salmon stocks exhibit a variety of life-cycle patterns. Most sockeye migrate from lakes to spawning grounds in rivers. However, there are stocks that migrate from the ocean to rivers. They may remain in lower reaches of rivers for 1 to 2 years ("river-type") after hatching or, alternatively, they may migrate to sea after only a few months ("sea-type"). Once at sea, sockeye remain for approximately 4 years until reaching maturity and returning to their natal streams to spawn.

Unlike other North Pacific fishery information, salmon population data are not reported from bounded areas. Therefore, estimates of abundance are derived from two salmon research trawl surveys conducted along the Aleutians in August 1996 and again in 1997 (Carlson et al., 1996 and 1997). Both surveys reported that catches from the central and western Aleutians, including Amchitka, consisted almost entirely of immature pink, chum, or sockeye salmon. "Immature" is the age category in which individuals are 1-year old or greater but are not yet of spawning age. Near Amchitka, some source populations of these immature salmon are from Asia, and the greatest numbers are probably from the Bristol Bay watershed in western Alaska. The preponderance of 
immature individuals and lack of juveniles (age 0 to 1 ) in the trawl samples indicates that populations near Amchitka consist mostly of fish that dispersed far from their natal streams. However, there is an annual spawning run of a small population of pink salmon in Amchitka streams (Valdez et al., 1977).

The surface area covered by trawls in 1997 was 247 nautical miles (458 km), and all samples were taken within $20 \mathrm{~m}$ of the ocean surface. The number of pink, chum, and sockeye caught was 1,336; 2,311; and 1,074, respectively. Multiplying the surface length of the trawl net $(0.041 \mathrm{~km})$ by the distance sampled yields a surface area of $18.7 \mathrm{~km}^{2}$. Dividing the number of salmon caught by the surface area covered $\left(4,721\right.$ salmon $\left./ 18.7 \mathrm{~km}^{2}\right)$ yields an abundance measure of 252 salmon per $\mathrm{km}^{2}$. Most of the salmon collected during the surveys were caught over, or shoreward of, the 200-m depth contour.

Estimates of salmon biomass are accomplished by multiplying the known average weight of each species (ADFG, 1994) by the number of salmon per area. The average weights reported for chum, sockeye, and pink salmon are $5.7 \mathrm{~kg}, 2.7 \mathrm{~kg}$, and $1.6 \mathrm{~kg}$, respectively. The mass estimate is as follows: $(2,311$ chum $\times 5.7 \mathrm{~kg})+(1,074$ sockeye $\times 2.7 \mathrm{~kg})+(1,336$ pink $\times 1.6 \mathrm{~kg})=18,210 \mathrm{~kg}$ salmon. Dividing this mass by the area sampled $\left(18,210 \mathrm{~kg} / 18.7 \mathrm{~km}^{2}\right)$ yields a biomass estimate of $974 \mathrm{~kg}$ salmon $/ \mathrm{km}^{2}$.

In contrast to salmon, dolly varden spend a majority of their lives in or near freshwater. Also, the source of the population potentially exposed to contaminants is local, inhabiting Amchitka streams. Growth and migration of Amchitka dolly varden populations are described in Valdez et al. (1977). On Amchitka, dolly varden spawned in streams during October and November and remained in freshwater habitats for 3 or 4 years, although immature fish close to the sea often ventured offshore but remained close to stream mouths. Individuals 3 or 4 years old migrated to the sea in June and July and remained there for an average of 73 days. Dolly varden do not stray far from shore, as none were captured farther away than $1 \mathrm{~km}$. After returning to natal streams and spawning, about half of the adults survived and spawned the following year. Some individuals spawned three consecutive years.

The number of dolly varden occupying the ocean environment surrounding Amchitka is estimated by multiplying the number of migrating adults in one stream by the total number of streams on the island that do not have barriers (high cliffs or gravel-sand dikes) to the sea. In Midden Cove Stream on Amchitka, 812 downstream migrants were captured. There are 17 streams on the island that are free 
of barriers. Thus, 17 streams multiplied by 812 dolly varden yields an estimate of 13,804 dolly varden entering the sea each year. The surface area of the band of water within $1 \mathrm{~km}$ of the Amchitka coast is estimated from NOAA's navigation chart (NOAA, 1976) to be $125 \mathrm{~km}^{2}$. Dividing the estimate of the number of dolly varden by this surface area $(13,804)$ yields 110 dolly varden/ $/ \mathrm{km}^{2}$. The most frequently occurring size class of dolly varden at sea was 130 to 134 millimeters (mm). At this length, they would weigh significantly less than $0.5 \mathrm{~kg}$. As a conservative estimate (overestimate), it is assumed that the average weight of a potentially exposed dolly varden is $0.5 \mathrm{~kg}$. Multiplying 13,804 dolly varden by $0.5 \mathrm{~kg}$ gives an estimated weight of $6,902 \mathrm{~kg}(0.6902 \mathrm{mT})$ for dolly varden at sea. Thus, the biomass of evenly dispersed dolly varden is $6,902 \mathrm{~kg} / 125 \mathrm{~km}^{2}$ or $55 \mathrm{~kg} / \mathrm{km}^{2}$.

\section{A.10.2.2 Marine Mammals}

\section{Steller Sea Lion, Eumetopias jubatus}

Listed by the USFWS as a federally endangered species in 1997, Steller sea lions have undergone a significant amount of study over the past several years. The body of recent pertinent biological information is reviewed in NMFS (2000).

The distribution of Steller sea lions approximates a northward projecting arc, with its eastern terminus located off the coast of southern California and its western terminus located off the coast of northern Japan. The northern portion of the arc extends through the Aleutians and Bering Sea. Steller sea lions are large mammals, as adult females and males average 579 pounds (lbs) (263 kg) and 1,245 lbs $(566 \mathrm{~kg})$, respectively (ADFG, 1994). The average birth weight of a pup is $51 \mathrm{lbs}(23 \mathrm{~kg})$. Females give birth to a single pup at rookeries in early June. Mating occurs one to two weeks after birth, but implantation is delayed until early October. Most individuals return to their natal rookery when they attain maturity. The average age of female and male maturity is 6 years, but females attain maximum size by 7 years, whereas growth of males is not complete until they reach age 12. Maximum life expectancy for Steller sea lions is approximately 20 years.

Although much is known of the on-shore distribution of Steller sea lions at aggregation (haulout) and breeding (rookery) locations, their distribution at sea is not as well understood. Adult Steller sea lions are highly vagile, dispersing over broad areas to feed. Foraging forays extend from the shore out to the continental shelf break, the inner edge of which is along the $200-\mathrm{m}$ isobath. Adult females are 
usually located closer to shore than males. Because they remain close to rookeries during breeding season or when they are nursing a pup, females remain within 20 nautical miles $(37 \mathrm{~km})$ of land.

Merrick and Loughlin (1997) described foraging patterns of 14 females. In the summer, duration of offshore trips ranged between 18 and 25 hours (h), and the average trip length of five tracked individuals was $17 \mathrm{~km}$. Dive time for these individuals was 4.7 hours per day (h/d). Females that were not supporting a pup in the winter spent up to $24 \mathrm{~d}$ at sea, and trip length and duration was longer for all females. Winter trip length averaged $133 \mathrm{~km}$, and average trip duration was $204 \mathrm{~h}$. Average home range estimates for females of $47,579 \mathrm{~km}^{2}$ were very large in the winter, although confidence intervals ( \pm 1 S.D.) of $26,704 \mathrm{~km}^{2}$ also were large. Information regarding the at-sea distribution of males is not as well studied, but it is assumed that their home range is much greater than that of females. The distribution of males and females in the water column does not differ. Adults of both sexes regularly feed from the surface to a maximum depth of $250 \mathrm{~m}$, and yearlings are capable of dives to $70 \mathrm{~m}$.

The National Marine Mammal Laboratory maintains a database of Steller sea lion counts including censuses of Amchitka. Year 2000 counts from aerial photos showed groups of Steller sea lions at three of six rookeries or haulouts. There were 213 juvenile (nonpup) and adult sea lions counted from the 2000 census. The census was done in the June and July breeding season, so it is likely that a majority of individuals, especially females, in the Amchitka population were on shore. Assuming 10 percent of the population was feeding at sea results in a total population estimate of 234 nonpups $(213 \times 0.1+213=234)$. Assuming equal sex ratios and an even age distribution $(25$ percent each of adult males, adult females, juvenile males, and juvenile females) results in an estimate of $72,745 \mathrm{~kg}$ for the total weight of the Amchitka Steller sea lion population. Juvenile weights are arbitrarily assigned as one-half the average adult male and female weights, 263 and $566 \mathrm{~kg}$, respectively. Therefore, $0.25 \times(566 \mathrm{~kg}+263 \mathrm{~kg}+283 \mathrm{~kg}+131.5 \mathrm{~kg}) \times 234=72,745 \mathrm{~kg}$. The surface area of the 200-m isobath around Amchitka roughly estimated from NOAA's navigation chart (NOAA, 1976) is $3,570 \mathrm{~km}^{2}$. Dispersing Steller sea lion mass evenly throughout this surface area $\left(72,745 \mathrm{~kg} / 3,570 \mathrm{~km}^{2}\right)$ results in a biomass measure of $20 \mathrm{~kg}$ sea lion/ $\mathrm{km}^{2}$. If all Steller sea lions disperse evenly between the shores of Amchitka to the 200-m isobath, then there are approximately 6.5 sea lions $/ 100 \mathrm{~km}^{2}$ (234 sea lions $/ 3,570 \mathrm{~km}^{2}=0.065$ sea lions $\left./ \mathrm{km}^{2}\right)$. 


\section{A.10.2.3 Derivation of Contaminated Fraction}

When an organism comes into contact with chemicals that are dispersed in air, water, soil, or food, the organism will take some of the chemical into its body. The uptake process can be characterized by a rate that is different for each chemical and each kind of organism. Likewise, chemicals in the body of the organism are eliminated. When the rate going in is the same as the rate going out, the uptake/elimination process is at equilibrium. The ratio of the concentration in the organism to the concentration in the exposure medium is the BCF. If the organism is exposed for a brief period of time, the resulting concentration in the body will not be as high as the value calculated with the BCF because the uptake process if not instantaneous. Likewise, the elimination process is not instantaneous, so some time will be required before the chemical is eliminated after the organism leaves the contaminated zone.

Fish and marine mammals typically move from place to place rather than stay in a single location. Therefore, they are expected to move into the plume, where they take up radionuclides, and then move out again into noncontaminated water, where the radionuclides are removed from the body by natural elimination processes. As this occurs, different fish or marine mammals come into the plume and are exposed. It is assumed for this screening evaluation that the processes of uptake in the plume and removal outside the plume balance each other, so the sum of concentrations in fish that have just entered the plume and are taking up radionuclides and the concentrations in fish that have just left the plume and are eliminating radionuclides is the same as if a single group of fish remained within the plume. Some time is required for the uptake process within the plume to come to equilibrium, so it is likely that animals that are in the plume at any one time have not taken up as much of any radionuclide as the $\mathrm{BCF}$ indicates. Despite this it is assumed that the organisms are present for sufficient time (e.g., weeks and months) to bioconcentrate radionuclides. Therefore, the calculated concentrations in fish and marine mammals are likely overestimated.

The fraction of fish or other dietary items that are considered contaminated by exposure to radionuclides in the predicted CORMIX plume is calculated as follows:

$$
\mathrm{FrC}=\mathrm{AP} \times \mathrm{BMDp} \times \mathrm{UF} / \mathrm{AFZ} \times \mathrm{BMDfz}
$$


Where:

FrC $=$ Fraction of fish that are contaminated by exposure in the plume

$\mathrm{AP}=$ Area of the plume $\left(\mathrm{km}^{2}\right)$

BMDp = Biomass density in the plume, assumed to be the same as in the fishing zone $\left(\mathrm{mT} / \mathrm{km}^{2}\right)$

$\mathrm{UF} \quad=$ Use factor for fraction of time spent fishing in the plume relative to other areas

AFZ = Area of the fishing zone $\left(\mathrm{km}^{2}\right)$

$\mathrm{BMDfz}=$ Biomass density in the fishing zone $\left(\mathrm{mT} / \mathrm{km}^{2}\right)$

As an example, the fraction of mackerel caught in the assumed fishing zone that was calculated as exposed to radionuclides in the Long Shot CORMIX plume is as follows. It was assumed (Section A.10.2.2) that the zone in which Steller sea lions are found is bounded by the 200-m isobath around Amchitka Island. That zone has an area of approximately 3,570 km² (Section A.10.2.2). This corresponds to roughly $9 \mathrm{~km}$ from shore on the Bering Sea side and $15 \mathrm{~km}$ from shore on the Pacific Ocean side. For conservatism, it was assumed that the zone in which a subsistence fisher would fish (AFZ) around Amchitka Island is roughly half of that area, or $2,000 \mathrm{~km}^{2}$. It was further assumed that a typical subsistence fisher in the Aleut culture and communication area would fish in the vicinity of Amchitka Island 10 percent of the year. It is unlikely that most subsistence fishers in the Aleut culture and communication area spend as much as 10 percent of their fishing time within the 200-m isobath of Amchitka Island. Therefore, the use factor (UF) of 0.1 is conservative. The area of the Long Shot plume (AP) was calculated to be 7.20E+06 $\mathrm{m}^{2}$ (Table A-5) or 7.20E+00 $\mathrm{km}^{2}$. The biomass density in the plume was assumed to be the same as throughout the fishing zone (i.e., $6.5 \mathrm{mT} / \mathrm{km}^{2}$ ), as discussed in Section A.10.2.1. Biomass density of fish in the fishing zone is also assumed to be $6.5 \mathrm{mT} / \mathrm{km}^{2}$ (Section A.10.2.1). Therefore, the fraction of harvested fish that are contaminated is $\left(7.20 \mathrm{E}+00 \mathrm{~km}^{2} \times 6.5 \mathrm{mT} / \mathrm{km}^{2} \times 1.0 \mathrm{E}-01\right) /\left(2.0 \mathrm{E}+03 \mathrm{~km}^{2} \times 6.5 \mathrm{mT} / \mathrm{km}^{2}\right)=3.60 \mathrm{E}-04$. The fraction of fish that are contaminated by exposure in the plume $(\mathrm{FrC})$ was calculated for each plume by using the foregoing equation.

\section{A.10.3 Discussion of Uncertainties}

It is explicitly assumed that the concentration of radionuclides in biota is the concentration calculated by using the $\mathrm{BCF}$, which is the steady-state ratio of concentration in the biota to the concentration in 
the water. The steady state results when the rate of removal of the radionuclide from the body is the same as the rate of intake. If exposure is transient in the plume, there may not be enough time to reach the steady state. The DOE (2002) uses a kinetic model to calculate BCFs for mammals. This model predicts that in two days of exposure to the majority of the radionuclides of potential concern, the concentration in the body is 10 percent or less of the steady-state concentration, and it may take weeks or months to attain steady state. If exposed, marine mammals are moving about and staying in the plume for no more than a few days; therefore, this risk assessment, which assumes steady state, overestimates the concentration of those radionuclides in their tissues by at least an order of magnitude. It is also unlikely that steady state is reached in fish and other marine biota in a few days. Therefore, it is likely that the concentration in fish and other marine foods is also overestimated.

There is uncertainty in each of the terms of the equation used to calculate the contaminated fraction of the diet. Uncertainties about the area of the plume are discussed in Section A.6.3. The assumed biomass density found in the plume and in the remainder of the fishing zone are based on, or extrapolated from, the densities documented in large areas of the Bering Sea. Thus, the relative density of fish in the plumes and in the fishing zone is assumed to be the same. In the equation, the densities mathematically cancel each other. Therefore, this uncertainty has little consequence on the risk assessment results.

The use factor is uncertain because no data were available to indicate what fraction of the time subsistence fishers fish within the 200-m isobath of Amchitka Island. It was assumed that the fraction is 10 percent of the time, or about 36 days. It is unlikely that subsistence fishers in the Aleut culture and communication area spend as much as 10 percent of their fishing time within the $200-\mathrm{m}$ isobath of Amchitka Island. Therefore, the UF of 0.1 contributes to an overestimate of the contaminated fraction. Further, the area of the fishing zone can be defined in a variety of ways. The assumed area, $2,000 \mathrm{~km}^{2}$ (781 sq. mi.) is equivalent to a square roughly $45 \mathrm{~km}$ (28 mi.) on a side. It is approximately 0.1 percent of the Aleut culture and communication area. This further indicates the conservative nature of the screening risk assessment.

Combining the uncertainties of all terms, it is likely that the fraction of diet that is contaminated is overestimated, and is overestimated by at least one or two orders of magnitude. 


\section{A.10.4 Implementation}

The ratio of fish calculated to be in the area of each plume to the number of fish in the hunting/fishing area, as discussed above in Section A.10.2 and Section A.10.4, was used as a conservative fraction of fish and marine mammals in the diet that were assumed to be contaminated by contact with radionuclides within each of the plumes (see Section 5.5 of the main text). 


\section{A.11.0 Cancer Morbidity Risk Coefficients}

\section{A.11.1 Description}

Cancer Morbidity Risk Coefficients were used with IEFs to calculate the RRF. The radionuclide risk factor is multiplied by the daily flux (i.e., rate of release) of each radionuclide to calculate the annual contribution to excess cancer risk from radionuclides ingested and retained in the body from food. The CMRC is described in the following sections.

\section{A.11.2 Current Knowledge}

The CMRC (formerly termed cancer slope factor) is the central estimate in a linear model of lifetime radiation-induced cancer incidence (i.e., the expected cancer rate per unit [pCi]) of radionuclide absorbed by the body. The CMRCs are empirically derived from public health data and cancer risk models developed and approved by several government and international organizations. The risk models assume that the risk of cancer is proportional to the radionuclide dose. The CMRCs are adjusted for the fraction of radionuclide ingested that is retained by the body and for the variation of risk with age, gender, and target organ. They are intended to estimate risks over a 70-year exposure. Therefore, they apply to both children and adults. CMRCs for all of the radionuclides of potential concern are published by EPA (2001). They are presented in Table A-9.

\section{A.11.3 Discussion of Uncertainties}

There are unknowns in the derivation of cancer morbidity risk coefficients from reported cancer rates and modeled exposures (Eckerman et al. 1999). The EPA recognizes that the CMRCs include both uncertainty and variability, but no quantitative uncertainty was stated (Eckerman et al. 1999). The CMRC is a central tendency that is recommended by U.S. EPA for this type of screening risk assessment.

\section{A.11.4 Implementation}

The CMRCs presented in Table A-9 along with annual IEFs (see Table 4 in the main text) were used to calculate the radionuclide risk factor for annual risk of excess cancers from ingestion of radionuclides (see Table 5 in the main text). 
Table A-9

Cancer Morbidity Risk Coefficients for Radionuclides Selected for Screening Risk Assessment Modeling

\begin{tabular}{|c|c|c|c|}
\hline Radionuclide & $\begin{array}{l}\text { Cancer Morbidity } \\
\text { Risk Coefficient } \\
\qquad\left(p \mathrm{Ci}^{-1}\right)\end{array}$ & Radionuclide & $\begin{array}{l}\text { Cancer Morbidity } \\
\text { Risk Coefficient } \\
\left(\mathrm{pCi}^{-1}\right)\end{array}$ \\
\hline Tritium & $6.51 \times 10^{-14}$ & ${ }^{152}$ Gadolinium & $8.70 \times 10^{-12}$ \\
\hline Carbon-14 & $2.00 \times 10^{-12}$ & ${ }^{234}$ Uranium & $9.55 \times 10^{-11}$ \\
\hline Chlorine-36 & $4.44 \times 10^{-12}$ & ${ }^{236}$ Uranium & $9.03 \times 10^{-11}$ \\
\hline Strontium-90 & $6.88 \times 10^{-11}$ & ${ }^{238}$ Uranium & $8.66 \times 10^{-11}$ \\
\hline Yttrium-90 & $2.65 \times 10^{-11}$ & ${ }^{237}$ Neptunium & $8.29 \times 10^{-11}$ \\
\hline Technetium-93 & $4.00 \times 10^{-12}$ & ${ }^{239}$ Plutonium & $1.74 \times 10^{-10}$ \\
\hline lodine-129 & $3.22 \times 10^{-10}$ & ${ }^{240}$ Plutonium & $1.74 \times 10^{-10}$ \\
\hline Cesium-137 & $3.74 \times 10^{-11}$ & ${ }^{241}$ Plutonium & $2.28 \times 10^{-12}$ \\
\hline Samerium-151 & $8.07 \times 10^{-13}$ & ${ }^{241}$ Americium & $1.34 \times 10^{-10}$ \\
\hline Europium-152 & $8.70 \times 10^{-12}$ & & \\
\hline
\end{tabular}




\section{A.12.0 Limits to Cancer Risk}

\section{A.12.1 Description}

The upper limit of radionuclide exposure is an amount of radionuclides that should result in a very small risk of cancer in addition to the risk from background radiation, fallout, and chemical exposures. The risk of radiation-induced cancer is thought to be proportional to the total dose of radionuclides. Therefore, establishing a limit to cancer risk is necessary to determine whether the risk from radionuclide flux is below a threshold for safety.

\section{A.12.2 Current Knowledge}

For this assessment, limits to lifetime excess cancer risk must be chosen. There are no published rules that establish an acceptable cancer risk, in part because persons who are exposed may not consider any risk acceptable if it does not result from their chosen lifestyle. However, EPA generally does not require remediation of a site where the combined cancer risk is below one excess cancer case in 10,000 persons (EPA, 1990a and 1998). This risk is expressed as the number $1 \times 10^{-4}$. A lower lifetime risk of one excess contamination-caused cancer case in 1 million persons is considered to be below the level of concern (EPA, 1990a and 1998) because the frequency of cancer morbidity from all causes is several orders of magnitude higher. This risk is expressed as the number $1 \times 10^{-6}$. If the calculated lifetime cancer morbidity risk from the release of radionuclides is below $1 \times 10^{-6}$, it is inferred that cancer risk from the radionuclides is negligible.

\section{A.12.3 Discussion of Uncertainties}

No quantitative value can be put on uncertainty associated with the threshold of $1 \times 10^{-6}$, but some observations are offered here for perspective.

- The U.S. EPA routinely uses a cutoff value of $1 \times 10^{-6}$ (one per million persons exposed) as a value below which risk is so negligible that it does not need to be considered further.

- Studies of risks to subsistence consumers of fish in the Barents Sea (NDE, 2002) and the Kara Sea (ONR, 1997) from radionuclides dumped as nuclear waste suggest cancer risks in the range of about $1 \times 10^{-8}$ to about $3 \times 10^{-7}$. These risks, which are estimated for waste dumped for several years directly into the sea or carried downriver from dump sites near the sea, are higher than any of the base-case results for Scenarios 1 through 9. 


\section{A.12.4 Implementation}

A lower-limit lifetime cancer risk of $1 \times 10^{-6}$ was used as the risk threshold below which it will be inferred that cancer risk is negligible. 


\section{A.13.0 Calculation of Risks}

The final output of the previous series of steps is the RRF. One uses the annual IEFs (Section A.9.0), fraction of contaminated diet (Section A.10.0), and the CMRCs (Section A.11.0) to calculate RRFs. The equation for RRF is (risk/year per $\mathrm{pCi} / \mathrm{d})^{-1}=\mathrm{IEF}(\mathrm{d} / \mathrm{year}) \times($ risk/pCi) (see Table 5 in the main text). The RRFs were used by DRI to compute risks from predicted fluxes.

The RRF was used to calculate annual radionuclide risks for the fluxes predicted to occur at various times. The RRF is the risk resulting from one unit of flux (i.e., $1 \mathrm{pCi} / \mathrm{d}$ ). For example, an RRF for tritium was calculated in tables in the text of the report as $1.16 \times 10^{-25}(\mathrm{pCi} / \mathrm{d})^{-1}$. This risk factor was used by DRI to calculate the expected risk level from the flux of tritium computed by the groundwater transport model. The equation for this calculation is risk $=$ flux $(\mathrm{pCi} / \mathrm{d}) \times \mathrm{RRF}(\mathrm{pCi} / \mathrm{d})^{-1}($ Table 5 in the main text).

The RRFs were used to calculate cancer risks from each radionuclide using the flux predictions. The risks from all radionuclides were summed to compute the risk from each year's predicted radionuclide fluxes. These values were then used to calculate the cumulative lifetime risk. The reported risks are the sum of risks calculated for each time step of the groundwater model over a period of 70 years. For example, the lifetime risk reported to occur one year after the first detonation is the risk expected for a 70-year exposure beginning at year one. A similar sum was computed for each time step. Results from all three sites were added to calculate the risk from possible exposure to radionuclides to marine life from the three plumes.

\section{A.13.1 Discussion of Uncertainties}

There is no uncertainty in the mathematical process of calculating cancer risks, which involves multiplying numbers calculated according to the foregoing risk assessment model elements. The risk is calculated by multiplying the radionuclide flux at each time step of the groundwater model by the RRF. RRF is calculated by multiplying the IEF by the CMRC. 


\section{A.14.0 Relationships of Site Closure Activities}

There are three main activities in the overall site closure plan: (1) the groundwater model, (2) the screening risk assessment, and (3) the closure plan itself. All of these activities are governed by DOE. The material in this report advances the approach, methods, and data by which the screening risk assessment was performed and reported. 


\section{A.15.0 References}

Akar, P. J., and G. H. Jirka. 1991. CORMIX2: An Expert System for Hydrodynamic Mixing Zone Analysis of Conventional and Toxic Submerged Multiport Discharges, EPA/600/3-91/073. Athens, GA: U.S. Environmental Protection Agency, Environmental Research Laboratory.

Akar, P. J., and G. H. Jirka. 1994. "Buoyant Transport and Mixing, Part I: Lateral Spreading in Strong Ambient Current." In J. Hydraulic Research 32:815-831.

Akar, P. J., and G. H. Jirka. 1995. "Buoyant Transport and Mixing, Part II: Upstream Spreading in Weak Ambient Current." In J. Hydraulic Research 33:87-100.

ADFG, see Alaskan Department of Fish and Game.

Alaskan Department of Fish and Game. 1994. Alaska Department of Fish and Game Wildlife Notebook Series.

Alaskan Department of Fish and Game. 2000a. Sea Otter, ADFG Marine Notebook. As accessed at www.state.ak.us/adfg/notebook/marine/seaotter.htm on 11 June.

Alaskan Department of Fish and Game. 2000b. Steller's Sea Lion, ADFG Marine Notebook. As accessed at www.state.ak.us/adfg/notebook/marine/sealion.htm on 14 June.

Alaskan Department of Fish and Game. 2002. Community Profile Database. As accessed at http://www.state.ak.us/adfg/subsist/geninfo/publctns/cpdb.htm on 18 June.

A/PIA, see Aleutian/Pribilof Islands Association.

Aleutian/Pribilof Islands Association. 2000. Verbal communication from Bob Patrick of A/PIA to Barney Cornaby of SAIC regarding diets of Aleuts, April 13 and 14.

Armstrong, R. H. 1977. "Weather and Climate." In The Environment of Amchitka Island, Alaska. Columbus, $\mathrm{OH}$ : Battelle Columbus Laboratories.

Baes, C. F., III, R. D. Sharp, A. L. Sjoren, and R. W. Shor. 1984. A Review and Analysis of Parameters for Assessing Transport of Environmentally Released Radionuclides Through Agriculture, ORNL-5786. Oak Ridge, TN: Oak Ridge National Laboratory.

Bloom, S. G., J. E. Howes, R. A. Ewing, and G. E. Raines. 1975. Amchitka Bioenvironmental Program, Pretest Estimates of Hypothetical Internal Radiation Doses from Cannikin via Marine Food Chains, BMI-171-143. Columbus, OH: Battelle Memorial Institute, Columbus Laboratories. 
Bowen, S. M., D. L. Finnegan, J. L. Thompson, C. M. Miller, P. L. Baca, L. F. Olivas, C. G. Geoffrion, D. K. Smith, W. Goishi, B. K. Esser, J. W. Meadows, N. Namboodiri, and J. F. Wild. 2001. Nevada Test Site Radionuclide Inventory, 1955-1992, Report LA-13859-MS, 27p. Los Alamos, NM: Los Alamos National Laboratory.

Carlson, H. R., K. W. Myers, E. V. Farley, H. W. Jaenicke, R. E. Haight, and C. M. Gutherie III. 1996. Cruise Report of the F/V Great Pacific Survey of Young Salmon in the North Pacific-Dixon Entrance to Western Aleutian Islands-July-August 1996, NPAFC Doc. 222. Juneau, AK: Auke Bay Laboratory, AFSC, NMFS, NOAA.

Carlson, H. R., E. V. Farley, R. E. Haight, K. W. Myers, and D. W. Welch. 1997. Survey of Salmon in the North Pacific Ocean and Southern Bering Sea--Cape St. Elias to Attu Island-July-August, 1997, NPAFC Doc. 254. Juneau, AK: Auke Bay Laboratory, AFSC, NMFS, NOAA.

Clark, W. G., G. St-Pierre, and E. S. Brown. 1997. Estimates of Halibut Abundance from NMFS Trawl Surveys, Technical Report 37. Seattle, WA: International Pacific Halibut Commission.

DOE, see U.S. Department of Energy.

DRI, see Desert Research Institute.

Desert Research Institute. 1999. Progress Report to U.S. Department of Energy. Las Vegas, NV.

Doneker, R. L., and G. H. Jirka. 1990. CORMIX1: An Expert System for Mixing Zone Analysis of Conventional and Toxic Single Port Aquatic Discharges, EPA-600/600/3-90/012. Athens, GA: U.S. Environmental Protection Agency, Environmental Research Laboratory.

Doneker, R. L. and G. H. Jirka. 1991. "Expert Systems for Design and Mixing Zone Analysis of Aqueous Pollutant Discharges." In J. Water Resources Planning and Management, ASCE, Vol. 117, No. 6, 679-697.

Eckerman, K.F., R.W. Leggett, C.B. Nelson, J.S. Puskin, and A.C.B. Richardson. 1999. Cancer Risk Coefficients for Environmental Exposure to Radionuclides. Federal Guidance Report No. 13, EPA 402-R-99-001. Washington DC: Office of Radiation and Indoor Air, United States Environmental Protection Agency.

EPA, see U.S. Environmental Protection Agency.

Fritz, L. W., and S. A. Lowe. 1998. Seasonal Distributions of Atka Mackerel (Pleurogrammus monopterygius) in Commercially-fished Areas of the Aleutian Islands and Gulf of Alaska, NOAA Tech. Memo NMFS-AFSC-92, 29 pp. Washington, DC: U.S. Department of Commerce. 
Gustafson, R. G., T. C. Wainwright, G. A. Winans, F. W. Waknitz, L. T. Parker, and R. S. Waples. 1997. Status Review of Sockeye Salmon from Washington and Oregon, NOAA Tech. Memo NMFS-NWFSC-33, 300 pp. Washington, DC: U.S. Department of Commerce.

Hard, J. J., R. G. Kope, W. S. Grant, F. W. Waknitz, L. T. Parker, and R. S. Waples. 1996. Status Review of Pink Salmon from Washington, Oregon, and California, NOAA Tech. Memo NMFS-NWFSC-25, 141 pp. Washington, DC: U.S. Department of Commerce.

Harris, S. G., and B. L. Harper. 1997. “A Native American Exposure Scenario.” In Risk Anal. 17, Number 6. New York, NY: Plenum Publishing Corporation.

Hoag, S. H., G. St. Pierre, and J. I. Forsberg. 1997. Bottom Area Estimates of Habitat for Pacific Halibut, Technical Report No. 36, 28 pp. Seattle, WA: International Pacific Halibut Commission.

Ianelli, J. N., L. Fritz, T. Honkalehto, N. Williamson, and G. Walters. 2000. Eastern Bering Sea Walleye Pollock Assessment, In publication, NMFS-AFSC, 92 pp. Seattle, WA.

IAEA, see International Atomic Energy Agency.

International Atomic Energy Agency. 1985. Sediment Kds and Concentration Factors for Radionuclides in the Marine Environment, IAEA Technical Report Series 247. Vienna: International Atomic Energy Agency.

ICRP, see International Commission on Radiation Protection.

International Commission on Radiation Protection. 1979-1988. Limits of Intakes of Radionuclides by Workers, ICRP Publication 30, Parts 1 through 4. New York, NY: Pergamon Press.

IPHC, see International Pacific Halibut Commission.

International Pacific Halibut Commission. 1998. The Pacific Halibut: Biology, Fishery, and Management, Technical Report 40, 64 pp. Anchorage, AK.

International Pacific Halibut Commission. 2000. "Pacific Halibut Stock Assessment and Fishery Evaluation." In Appendix A, Stock Assessment and Fishery Evaluation Report for the Groundfish Resources of the Bering Sea/Aleutian Islands Regions. Anchorage, AK: North Pacific Fishery Management Council.

Isaakson, J. S., and A. H. Seymour. 1968. Amchitka Bioenvironmental Program, Annual Progress Report July 1, 1967 - June 20, 1968, Radiometric and Elemental Analyses on Marine Organisms from Amchitka, Alaska. BMI-171-113. Columbus, OH: Batelle Memorial Institute, Columbus Laboratories.

IT, see IT Corporation. 
IT Corporation. 1999. Amchitka Subsurface Human Health Risk Assessment Interim Work Product. Las Vegas, NV.

Jackson, G. A., and C. D. Winant. 1983. "Effect of a Kelp Forest on Coastal Currents." In Continental Shelf Res. 2:75-80.

Jirka G. H. and R. L. Doneker. 1991. "Hydrodynamic Classification of Submerged Single Port Discharges.” In J. Hydraulic Engineering, ASCE, 117:1095-1112.

Jirka G. H. and P. J. Akar. 1991. "Hydrodynamic Classification of Submerged Multiport Diffuser Discharges.” In J. Hydraulic Engineering, ASCE, 117:1113-1128.

Jirka, G. H. 1992. "Use of Mixing Zone Models in Estuarine Waste Load Allocation," Part III of Technical Guidance Manual for Performing Waste Load Allocations, EPA-823-R-92-004, Book III: Estuaries. Edited by R. A. Ambrose and J. L. Martin. Washington, DC: U.S. Environmental Protection Agency.

Jirka, G. H., P. J. Akar, and J. D. Nash. 1996a. Enhancements to the CORMIX Mixing Zone Expert System: Technical Background." Ithaca, NY: DeFrees Hydraulics Laboratory, School of Civil and Environmental Engineering, Cornell University.

Jirka, G. H., R. L. Doneker, and S. W. Hinton. 1996b. User's Manual for CORMIX: A Hydrodynamic Mixing Zone Model and Decision Support System for Pollutant Discharges into Surface Waters. Athens, GA: U.S. Environmental Protection Agency, Environmental Research Laboratory.

Jirka, G. H., R. L. Doneker, and S. W. Hinton. 1996c. User's Manual for CORMIX: A Hydrodynamic Mixing Zone Model and Decision Support System for Pollutant Discharges into Surface Waters, Cooperative Agreement No. CX824847-01-0. Washington, DC: Office of Science and Technology, U.S. Environmental Protection Agency.

Johnson, O. W., W. S. Grant, R. G. Kope, K. Neely, F. W. Waknitz, and R. S. Waples. 1997. Status Review of Chum Salmon from Washington, Oregon, and California, NOAA Tech. Memo NMFS-NWFSC-32, 280 pp. Seattle, WA: U.S. Department of Commerce.

Jones, G. R. and G. H. Jirka. 1996. "Buoyant Surface Discharges into Water Bodies, Part 2: Prediction." In J. Hydraulic Engineering.

Jones, G. R., J. D. Nash, and G. H. Jirka. 1996a. "Buoyant Surface Discharges into Water Bodies, Part 1: Classification." In J. Hydraulic Engineering.

Jones, G. R., J. D. Nash, and G. H. Jirka. 1996b. CORMIX3: An Expert System for Mixing Zone Analysis and Prediction of Buoyant Surface Discharges. Ithaca, NY: DeFrees Hydraulics Laboratory, School of Civil and Environmental Engineering, Cornell University. 
Lebednik, P. A., and J. F. Palmisano. 1977. "Ecology of Marine Algae.” In The Environment of Amchitka Island Alaska. M. L. Merrit and R. G. Fuller, eds. U.S. Energy Research and Development Administration.

Lowe, S. A., and L. W. Fritz. 2000. "Assessment of Bering Sea/Aleutian Islands Atka Mackerel, Executive Summary." In Appendix A, Stock Assessment and Fishery Evaluation Report for the Groundfish Resources of the Bering Sea/Aleutian Islands Regions. Anchorage, AK:

North Pacific Fishery Management Council.

McAlister, W. B., C. Mahnken, R. C. Clark, Jr., W. J. Ingraham, J. Larrance, and D. Day. 1968. Oceanography and Marine Ecology in the Vicinity of Amchitka Island, USAEC Report BMI-171-112. Columbus, OH: Battelle Memorial Institute.

McAlister, W. B., and F. Favorite. 1977. “Oceanography,” pp. 331-352. In The Environment of Amchitka Island, Alaska. M. L. Merritt and R. G. Fuller, eds. Energy Research and Development.

Mendéz-Díaz, M. M., and G. H. Jirka. 1996. "Buoyant Plumes from Multiport Diffuser Discharge in Deep Coflowing Water.” In J. Hydraulic Engineering, ASCE Vol. 122:426-478.

Merrell, T. R., Jr. 1977. "Fishery resources of the Western Aleutians." In The Environment of Amchitka Island Alaska. M. L. Merrit and R. G. Fuller, eds. U.S. Energy Research and Development Administration.

Merrick, R. L., and T. R. Loughlin. 1997. "Foraging Behavior of Adult Female and Young-of-the-Year Steller Sea Lions (Eumetopias jubatus) in Alaskan Waters." In Canadian Journal of Zoology 75 (5):776-786.

Nash, J. D. and G. H. Jirka. 1996. "Buoyant Surface Discharges into Unsteady Ambient Flows." In Dynamics of Atmospheres and Oceans, 24:75-84.

NDE, see, Norwegian Department of the Environment.

NMFS, see National Marine Fisheries Service.

National Marine Fisheries Service. 2000. Biological Opinion for Listed Species in the Bering Sea Aleutian Islands Groundfish Fishery Management Plan and the Gulf of Alaska Groundfish Fishery Management Plan, Endangered Species Act Section-7 Consultation, Biological Opinion and Incidental Take Statement. Anchorage, AK: Alaska Region Sustainable Fisheries Division.

NMML, see National Marine Mammal Laboratory.

National Marine Mammal Laboratory. 2000. Steller Sea Lion Count Database. As accessed at www.nmml.afsc.noaa.gov/AlaskaEcosystems/sslhome/index.htm on 10 June.

NOAA, see National Oceanic and Atmospheric Administration. 
National Oceanic and Atmospheric Administration. 1976. North Pacific Ocean Bering Sea (Southern Part). Chart amended through 1990. Washington, DC: U.S. Department of Commerce.

Norwegian Department of the Environment). 2002. Radionuclide Uptake and Transfer in Pelagic Food Chains of the Barents Sea and Resulting Doses to Man and Biota. As accessed at http://www.npolar.no/transeff/Effects/Radionuclides/Progress on 2 October.

ONR, see Office of Naval Research.

Office of Naval Research. 1997. Radionuclides in the Arctic Seas from the Former Soviet Union: Potential Health and Ecological Risks. Livermore, CA.

Okkonen, S. R. 1996. "The Influence of an Alaskan Stream Eddy on Flow Through Amchitka Pass." In J. Geophys. Res. 101: 8839-8851.

Reed, R. K., and P. J. Stabeno. 1994. "Flow Along and Across the Aleutian Ridge." In J. Mar. Res. 52: 639-648.

Roden, G. I. 1995. "Aleutian Basin of the Bering Sea: Thermohaline, Oxygen, Nutrient, and Current Structure in July 1993." In J. Geophys. Res. 100: 13539-13554.

Simensted, C. A., J. S. Isakson, and R. E. Nakatani. 1977. "Marine Fish Communities.” In The Environment of Amchitka Island Alaska. M. L. Merrit and R. G. Fuller, eds. U.S. Energy Research and Development Administration.

Smith, D. K., B. K. Esser, and J. L. Thompson. 1995. Uncertainties Associated with the Definition of a Hydrological Source Term for the Nevada Test Site, UCRL-ID-120322. Livermore, CA: Lawrence Livermore National Laboratory.

Smith, D.K., Lawrence Livermore National Laboratory. 1997. Memorandum to J. Wille (IT Corporation) regarding radionuclides recommended by the UGTA Source and Transport Subcommittee of significance for remedial investigations at the Nevada Test Site, 2 April. Livermore, CA.

Spencer, P. D., D. H. Ito, and J. N. Ianelli. 2000. "Pacific Ocean Perch.” In Appendix A, Stock Assessment and Fishery Evaluation Report for the Groundfish Resources of the Bering Sea/Aleutian Islands Regions. Anchorage, AK: North Pacific Fishery Management Council.

Stabeno, P. J., and R. K. Reed. 1994. "Circulation in the Bering Sea Basin Observed by Satellite-Tracked Drifters: 1986-1993.” In J. Phys. Oceanogr. 24: 848-854.

U.S. Department of Commerce, Coast and Geodetic Survey. 1995. Tidal Current Tables, Pacific Coast of North America and Asia. 
U.S. Department of Energy. 2002. A Graded Approach for Evaluating Radiation Doses to Aquatic and Terrestrial Biota, DOE-STD-1153-2002. U.S. Department of Energy, Washington, DC. July.

U.S. Environmental Protection Agency. 1990a. Exposure Factors Handbook, EPA/600/8-89/043. Washington, DC: Office of Health and Environmental Assessment.

U.S. Environmental Protection Agency. 1990b. National Oil And Hazardous Substances Pollution Contingency Plan--Final Rule, Title 40 Code of Federal Regulations Part 300:666.

Washington, DC: Office of Health and Environmental Assessment.

U.S. Environmental Protection Agency. 1991a. Assessment and Control of Bioconcentratable Contaminants in Surface Waters. Washington, DC: Office of Water.

U.S. Environmental Protection Agency. 1991b. Technical Support Document for Water Quality-Based Toxics Control. Washington, DC: Office of Water.

U.S. Environmental Protection Agency. 1993. Wildlife Exposure Factors Handbook, Volume I of II, EPA/600/R-93/187a. Washington, DC: Office of Health and Environmental Assessment, Office of Research and Development.

U.S. Environmental Protection Agency. 1997. Exposure Factors Handbook, Update to Exposure Factors Handbook EPA/600/8-89/043, EPA/600/P-95/002Fa. Washington, DC: Office of Research and Development.

U.S. Environmental Protection Agency. 1998. Risk Assessment Guidance for Superfund, Volume I: Human Health Evaluation Manual, Part D, Standardized Planning, Reporting, and Review of Superfund Risk Assessments, Interim, Publication 9285.7-01D. Washington, DC: Office of Emergency and Remedial Response.

U.S. Environmental Protection Agency. 1999. Screening-Level Ecological Risk Assessment Protocol for Hazardous Waste Combustion Facilities (Peer Review Draft), EPA 530-D-99-001A. Washington, DC: Office of Solid Waste and Emergency Response.

U.S. Environmental Protection Agency. 2001. Radionuclide Table: Radionuclide Carcinogenicity-Slope Factors (Federal Guidance Report No. 13, Morbidity Risk Coefficients in Units of Picocuries). As accessed at http://www.epa.gov/radiation/heast/download.htm on 4 June.

USFWS, see U.S. Fish and Wildlife Service.

U.S. Fish and Wildlife Service. 1997. "Endangered and Threatened Wildlife and Plants; Change in Listing Status of Steller Sea Lion.” In Federal Register 62 (108):30772-30773.

USGS, see U.S. Geological Survey. 
U.S. Geological Survey. 1975. “Amchitka Island Quadrangle,” 667-340/62. Washington, DC: U.S. Government Printing Office.

Valdez, R. A., W. T. Helm, and J. M. Neuhold. 1977. "Aquatic Ecology." In The Environment of Amchitka Island Alaska. Columbus, $\mathrm{OH}$ : Battelle Columbus Laboratories.

Warren, B. A., and W. B. Owens. 1988. "Deep Currents in the Central Subarctic Pacific Ocean." In J. Phys. Oceanogr. 18: 529-551.

Witherell, D. 2000. Groundfish of the Bering Sea and Aleutian Islands Area: Species Profiles 2000. Anchorage, AK: North Pacific Fishery Management Council. 


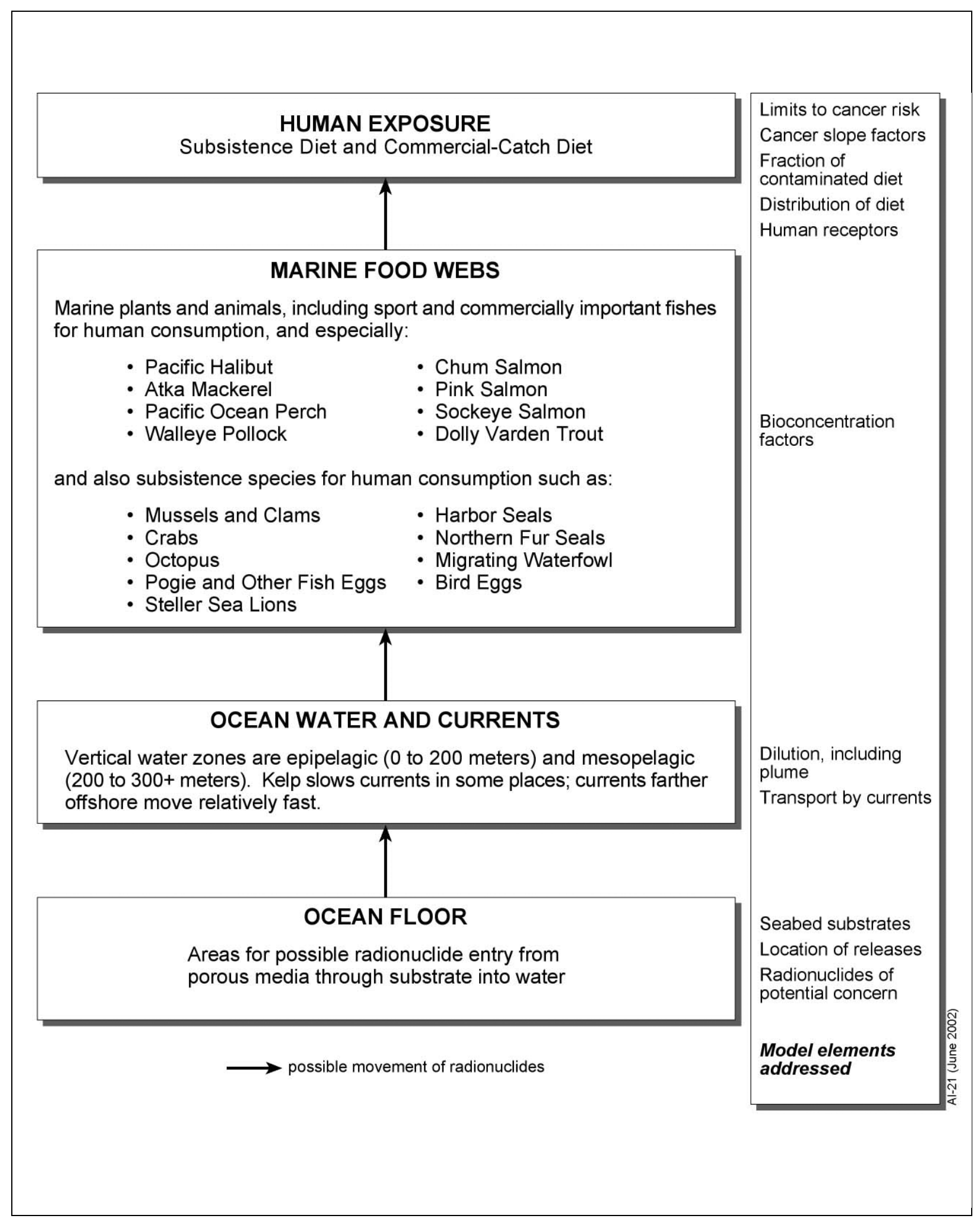

- Pacific Halibut

- Atka Mackerel

- Pacific Ocean Perch

Walleye Pollock
Sockeye Salmon

Dolly Varden Trout
Limits to cancer risk

Cancer slope factors

Fraction of

contaminated diet

Distribution of diet

Human receptors

factors plume

Transport by currents

Seabed substrates cation of releases

Radionuclides of potential concern

Model elements addressed

Figure A.1

Conceptual Risk Assessment Model and Model Elements 
Bering Sea
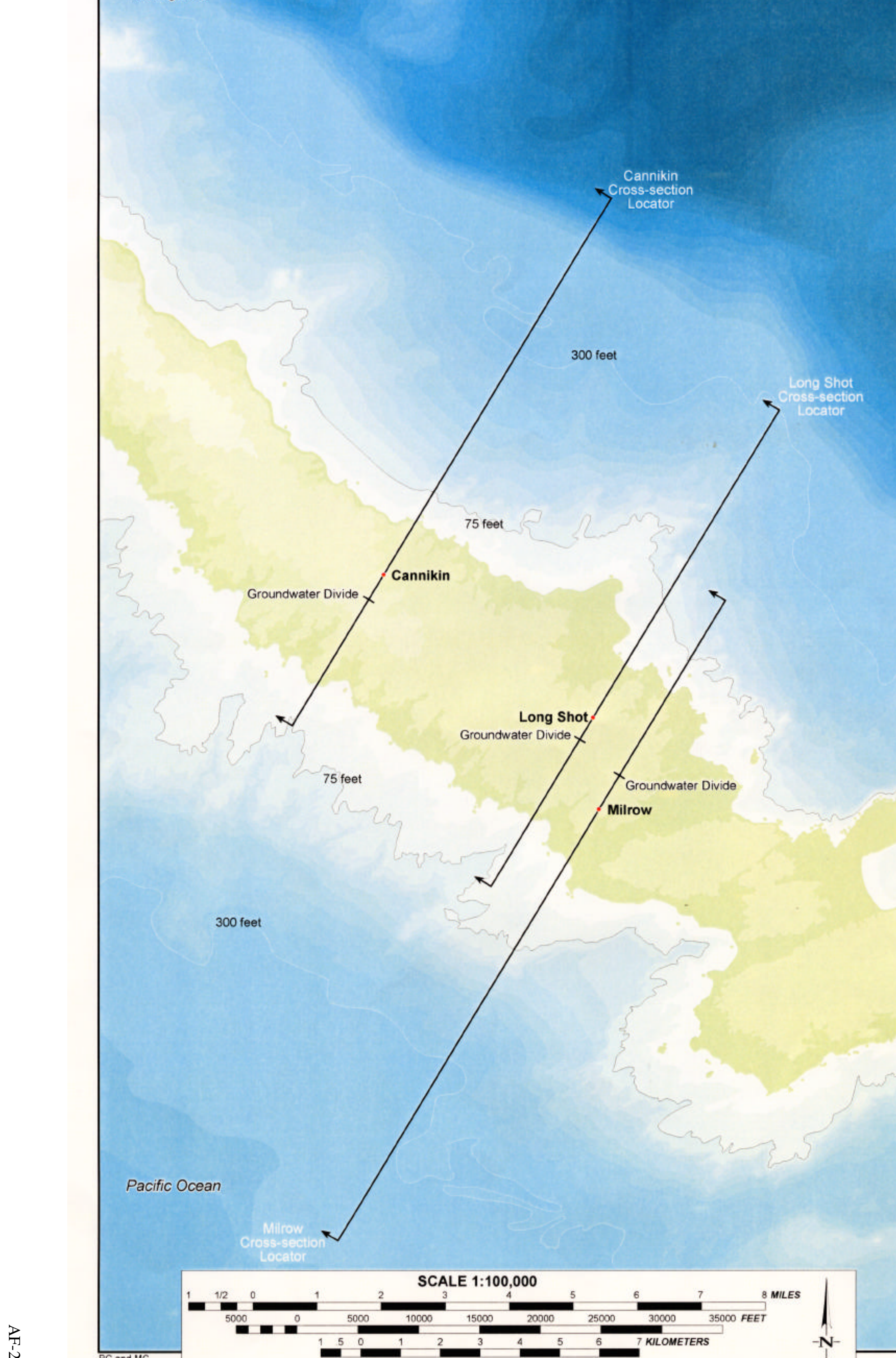

$x$

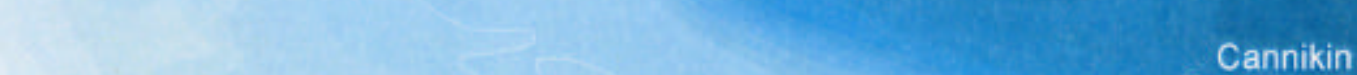

Cass-section

Locator

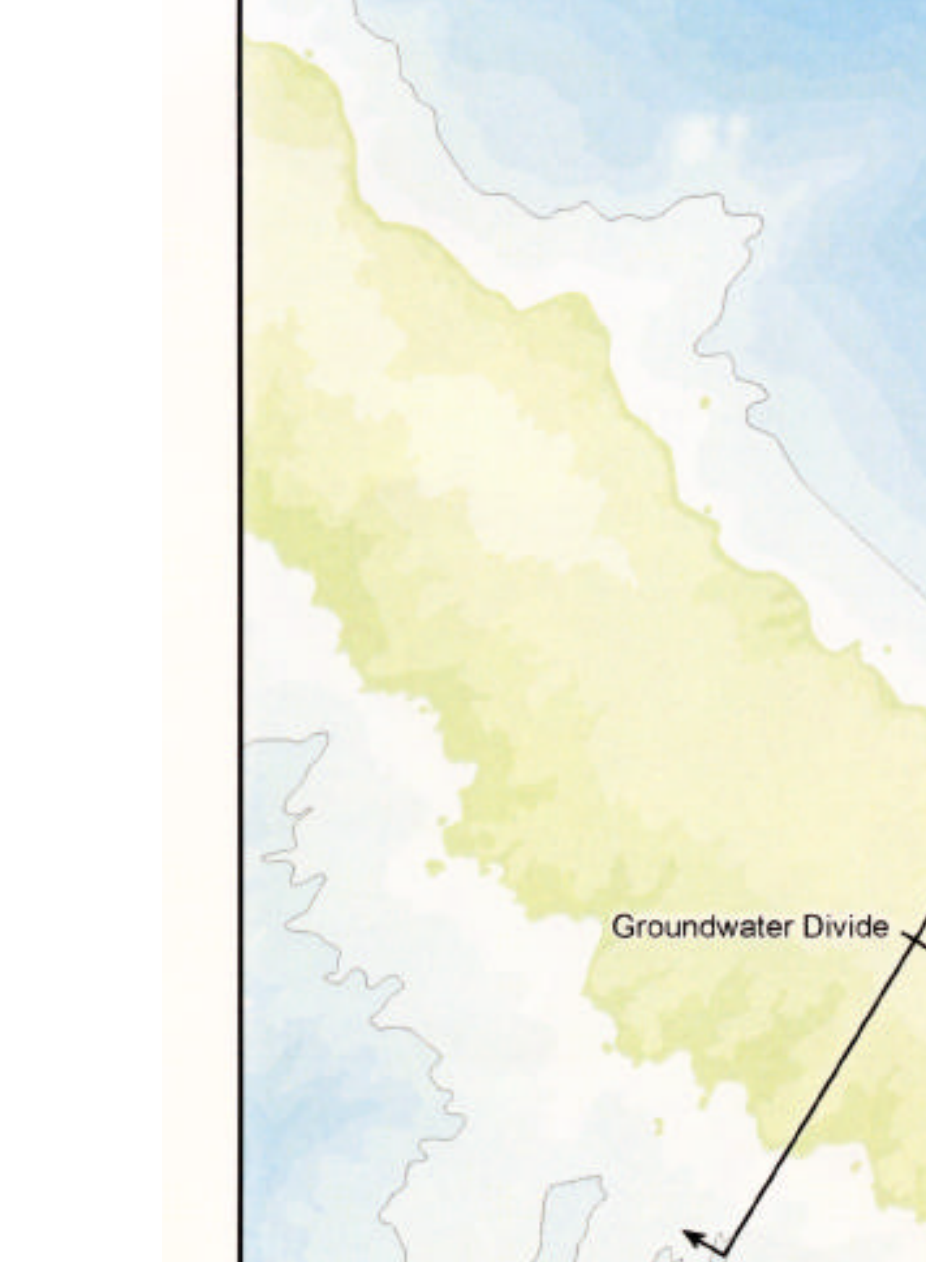

75 feet

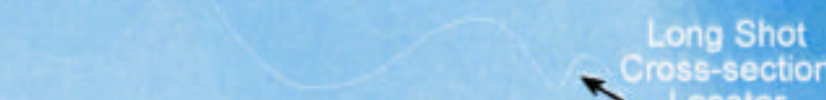
Groundwater Divide $\chi$

Pacific Ocean
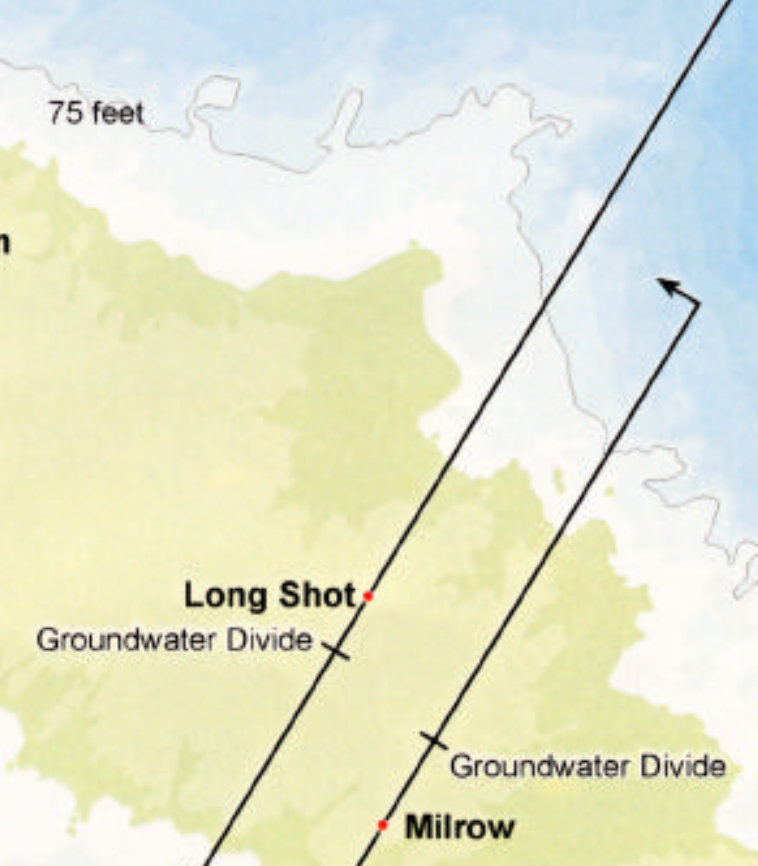

300 feet
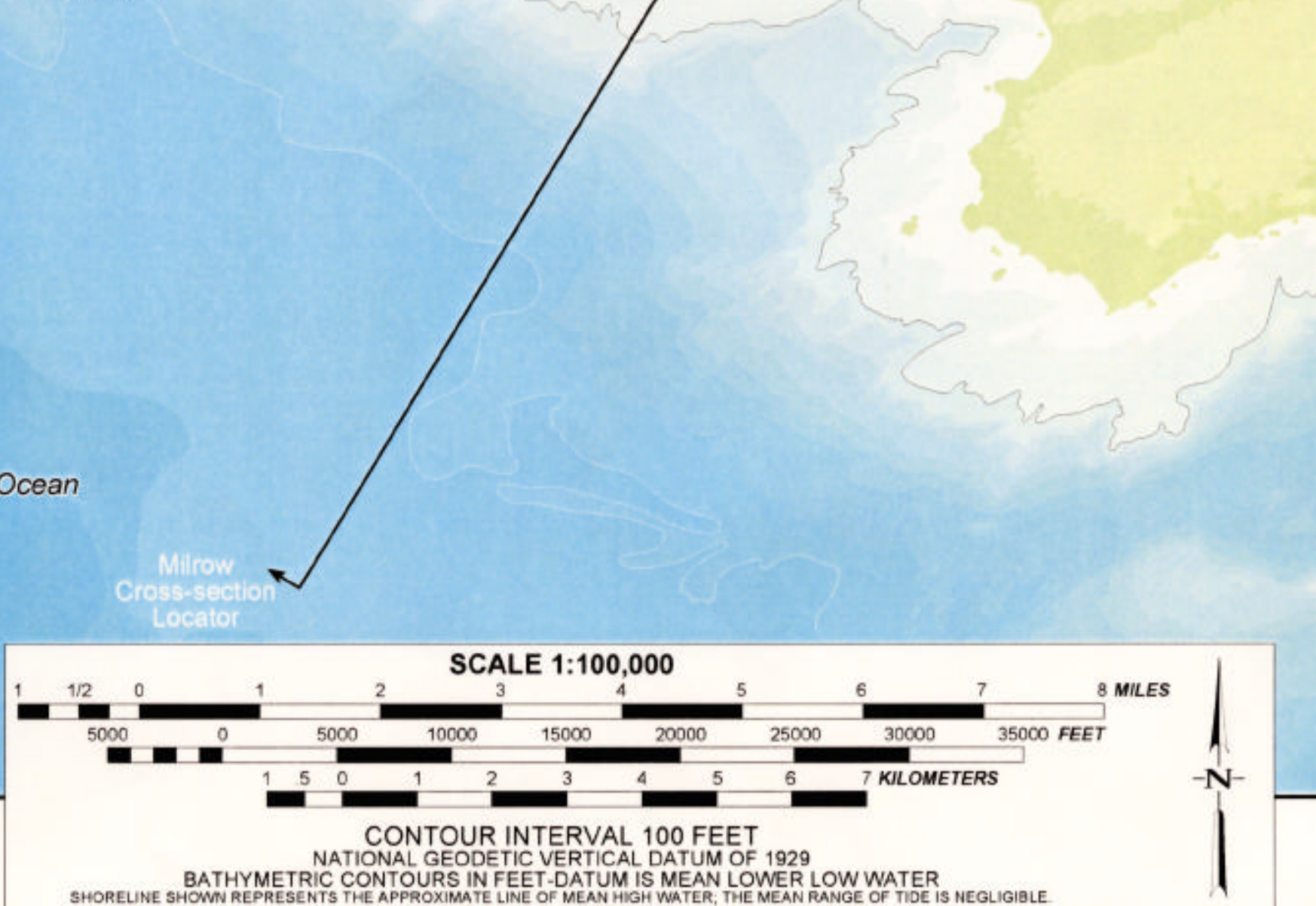
BATHYMETRIC CONTOURS IN FEET-DATUM IS MEAN LOWER LOW WATER
OWN REPRESENTS THE APPROXIMATE LINE OF MEAN HIGH WATER, THE MEAN RANGE OF TIOE IS NEGLIGIGLE. 

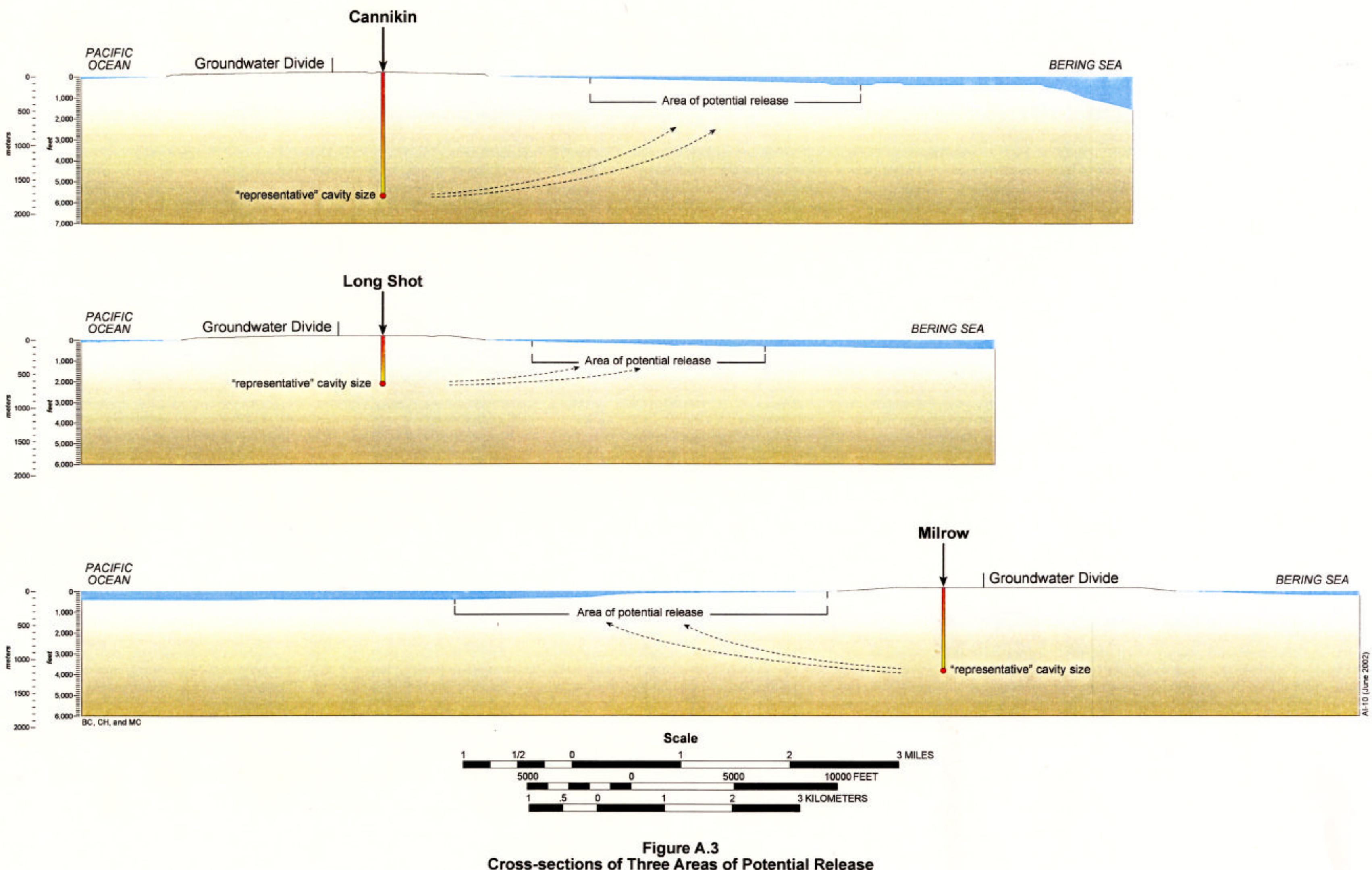

Cross-sections of Three Areas of Potential Release 


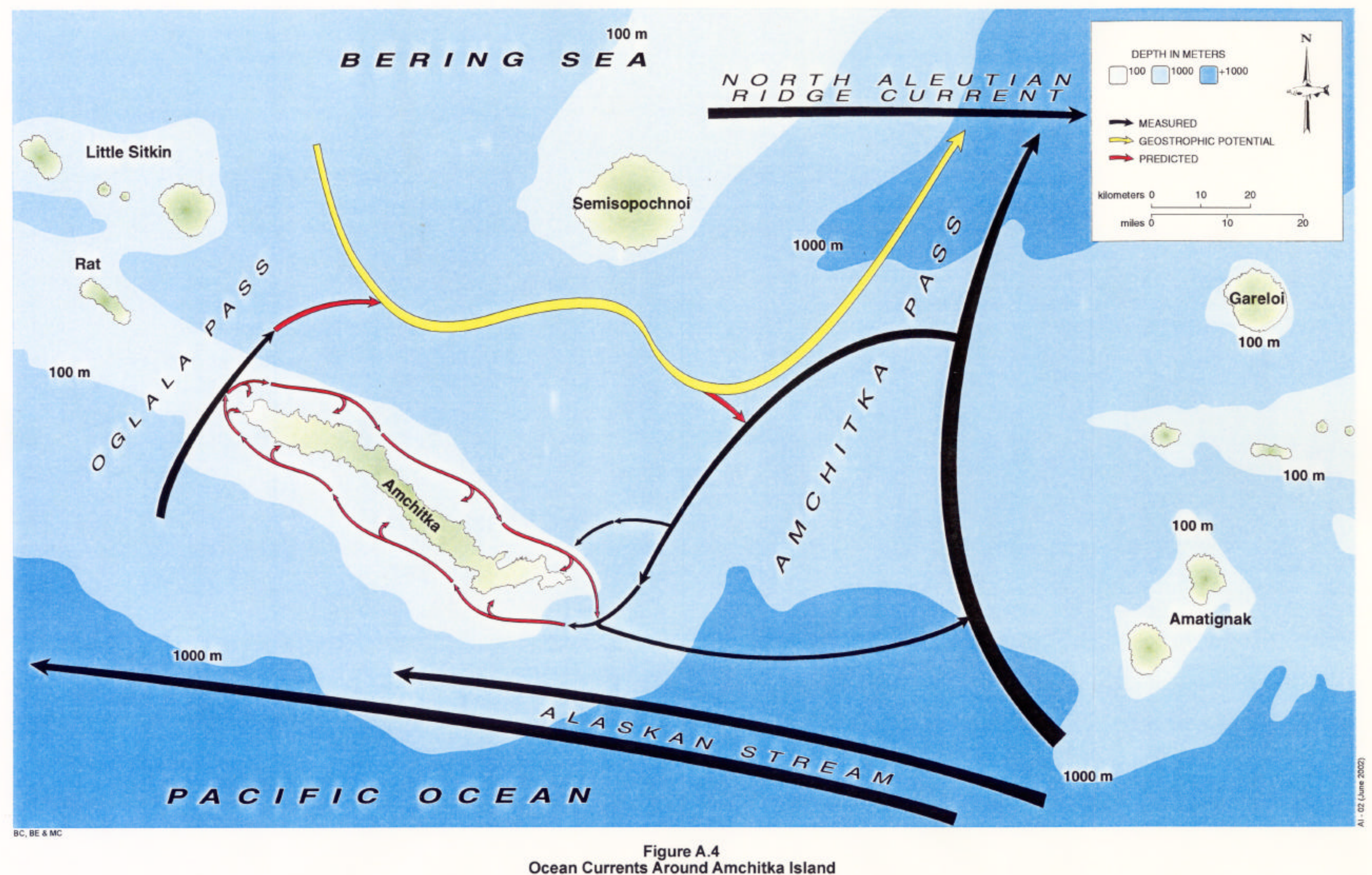



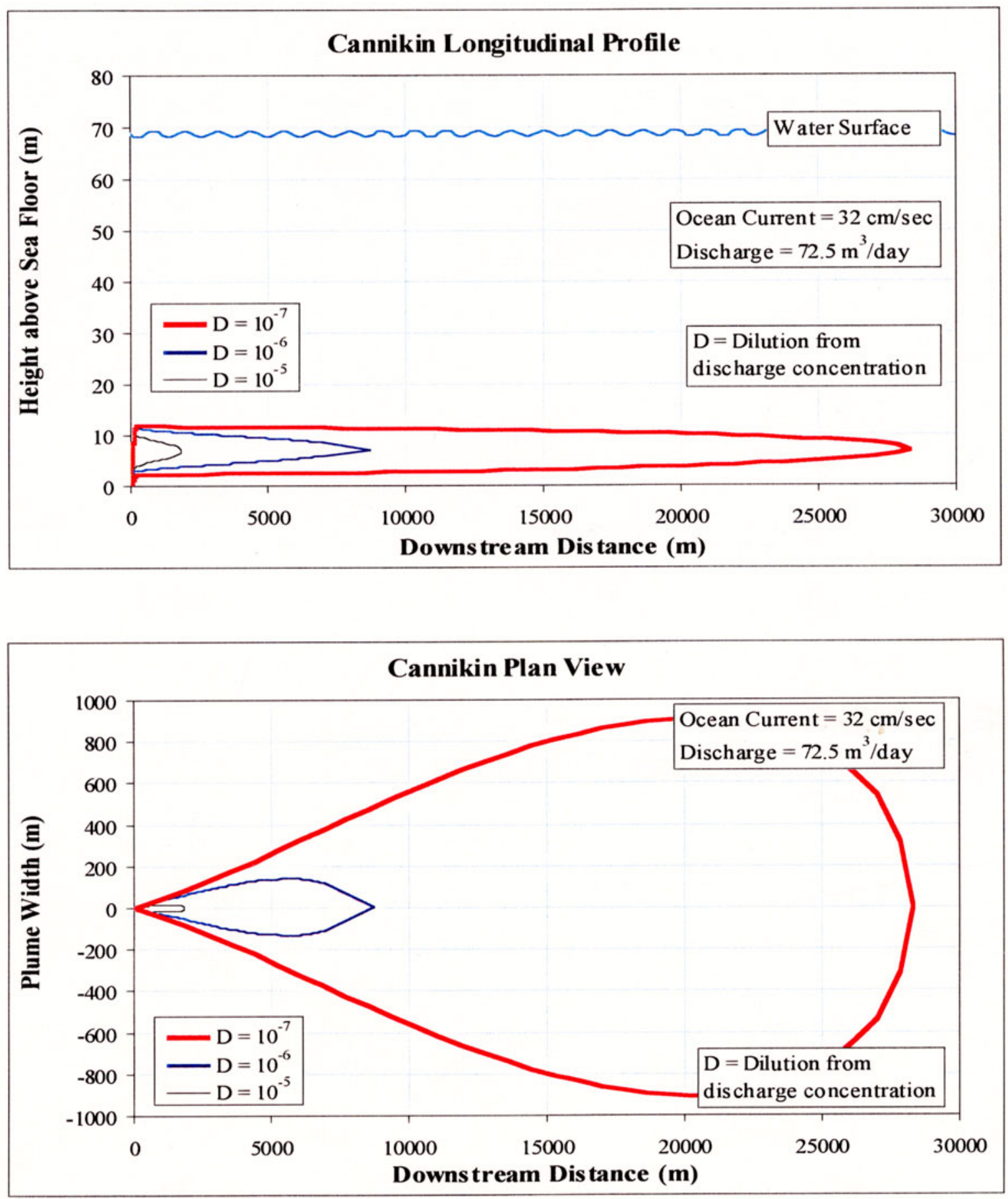

Figure A.5

Predicted Plume at Cannikin Using EPA's CORMIX Model 

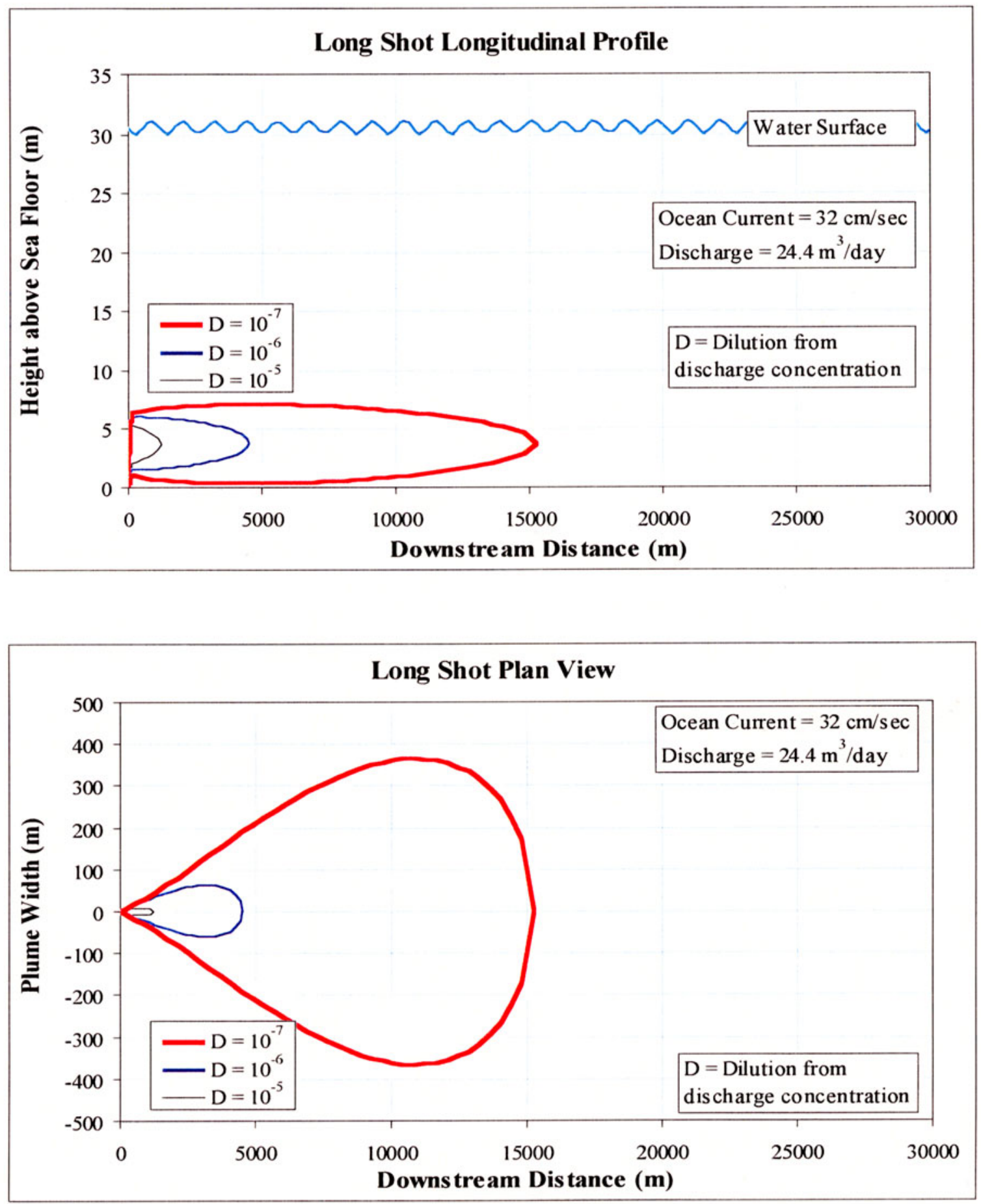

Figure A.6

Predicted Plume at Long Shot Using EPA's CORMIX Model 

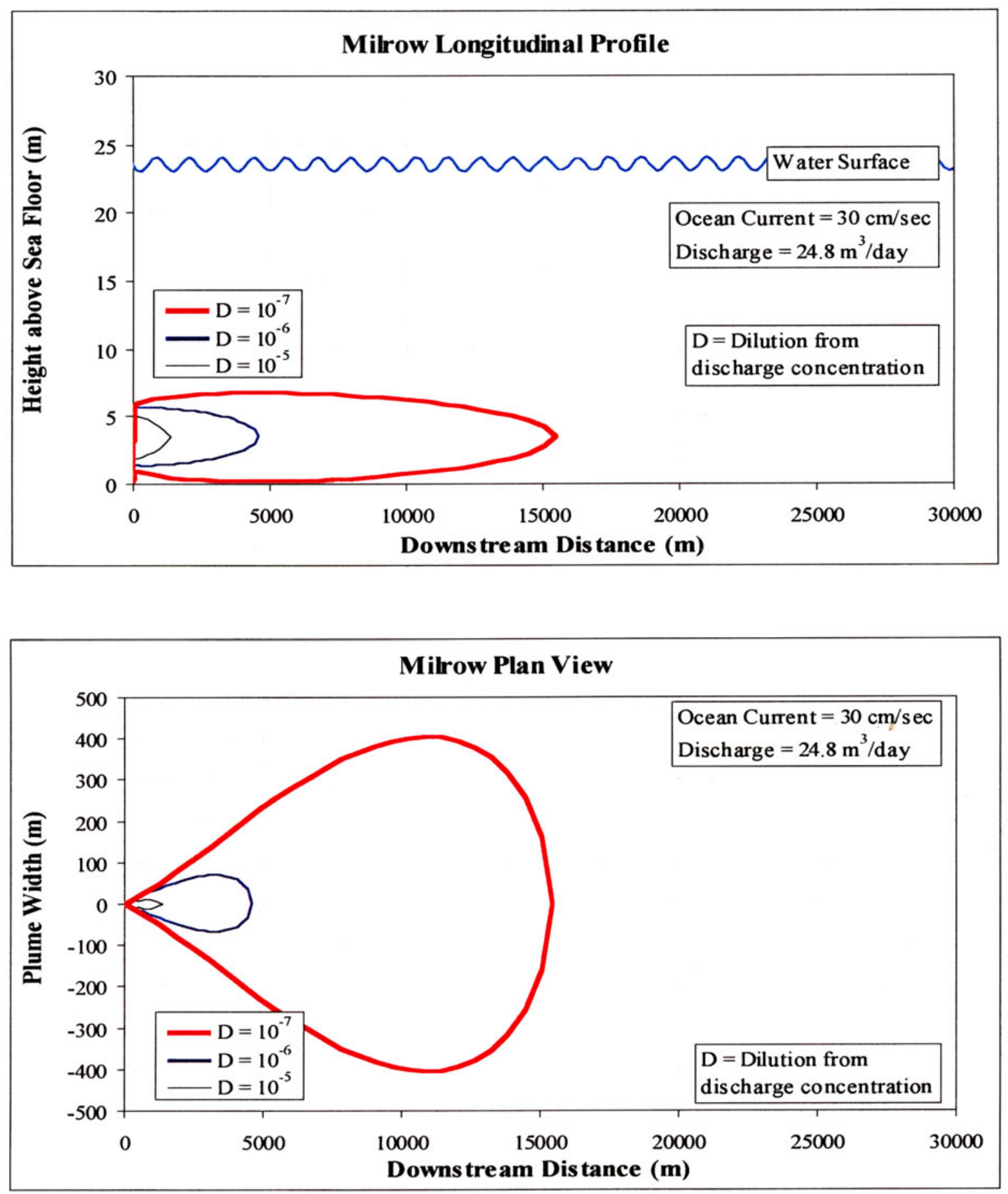

Figure A.7

Predicted Plume at Milrow Using EPA's CORMIX Model 

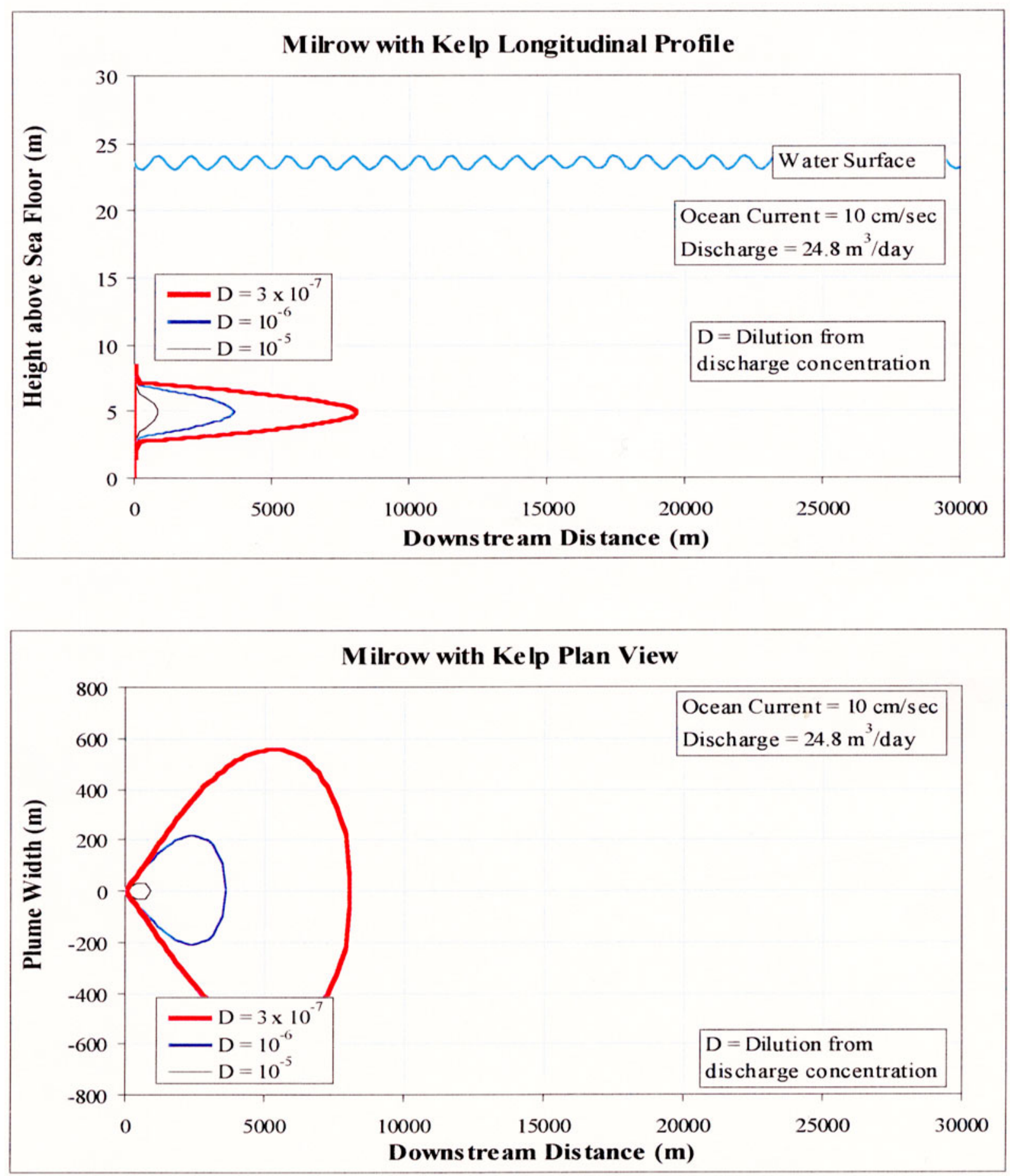

Figure A.8

Predicted Plume at Milrow With Kelp Using EPA's CORMIX Model 


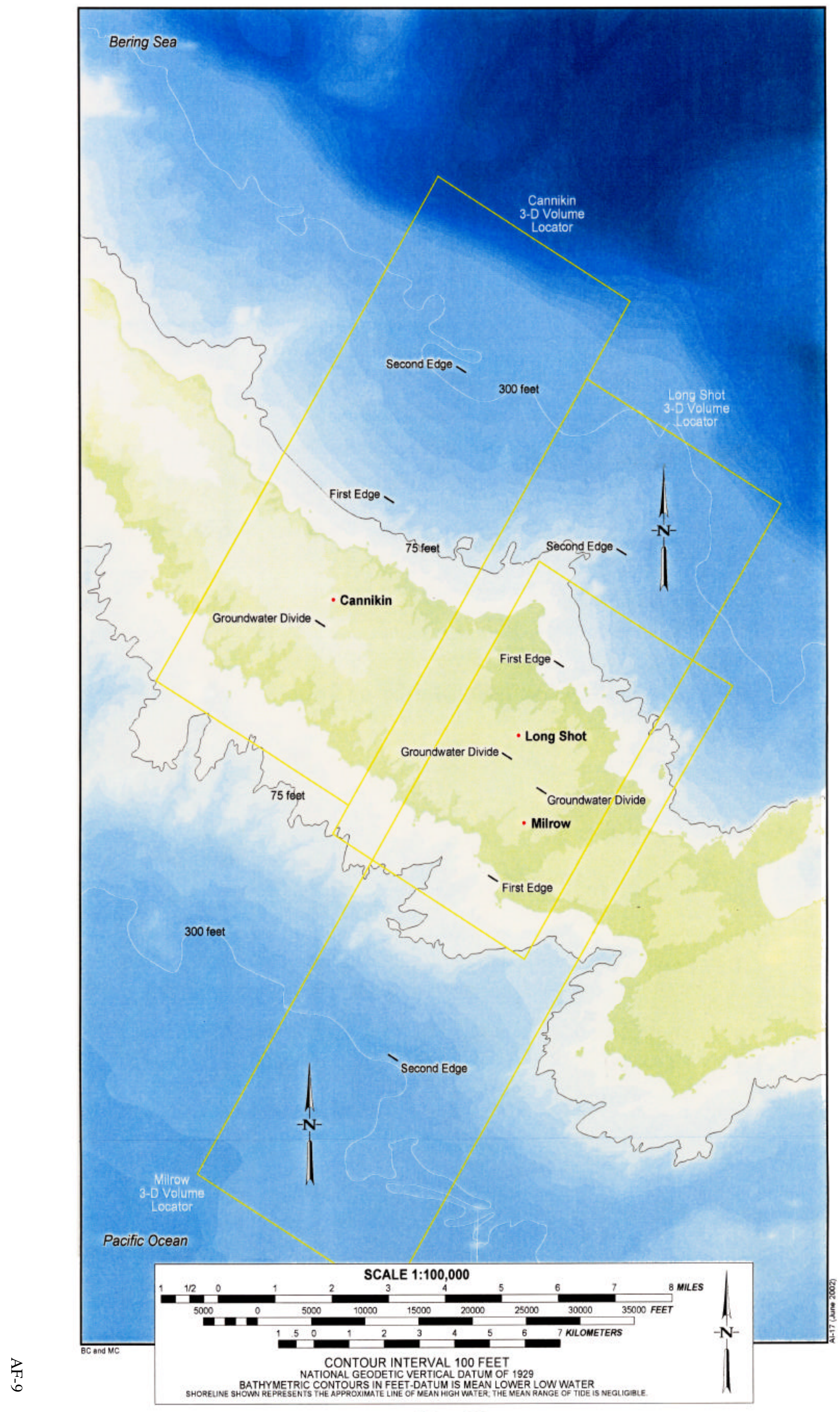

Figure A.9

Locations of 3-D Volumes for Three Areas of Potential Release 


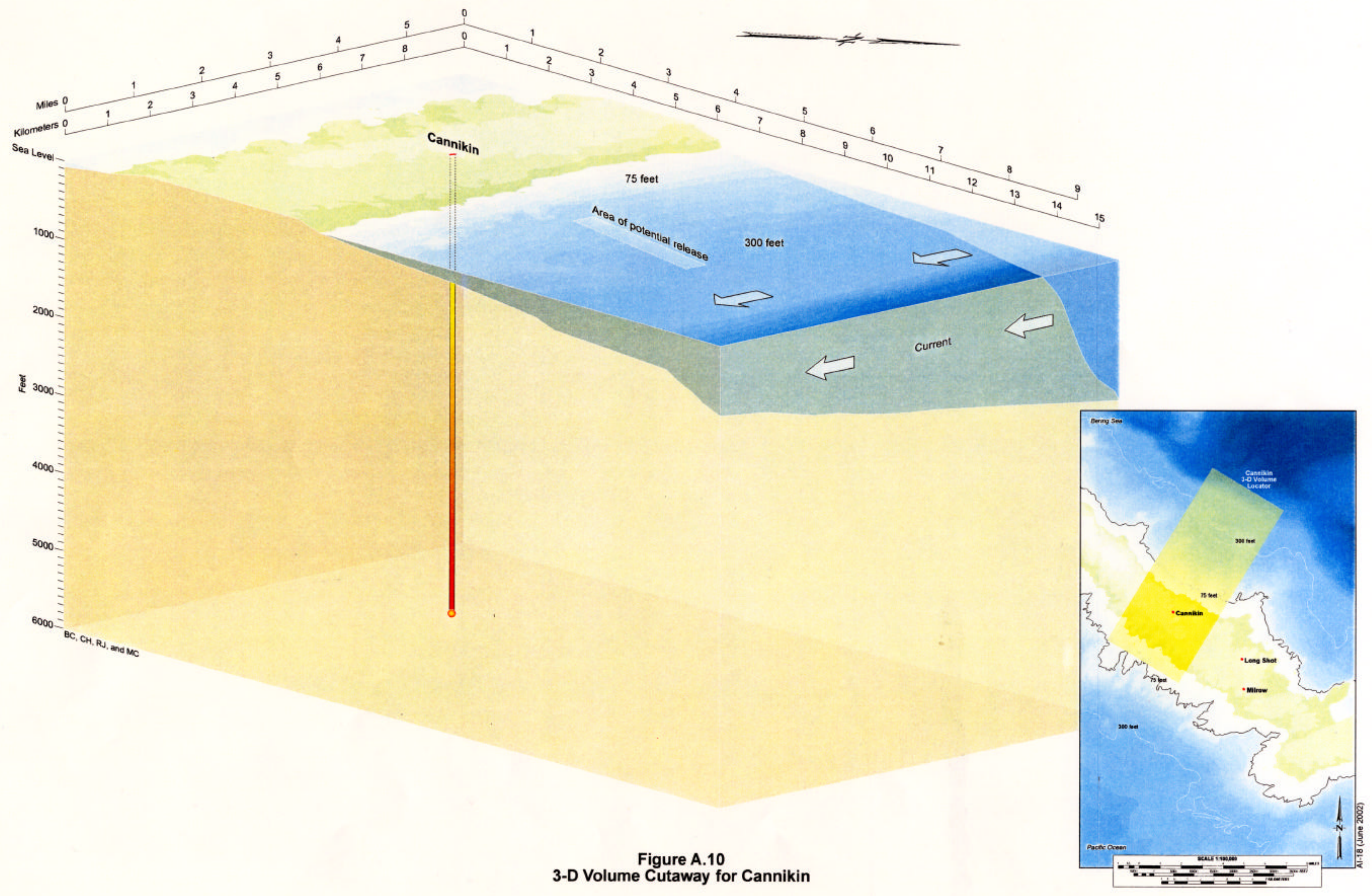




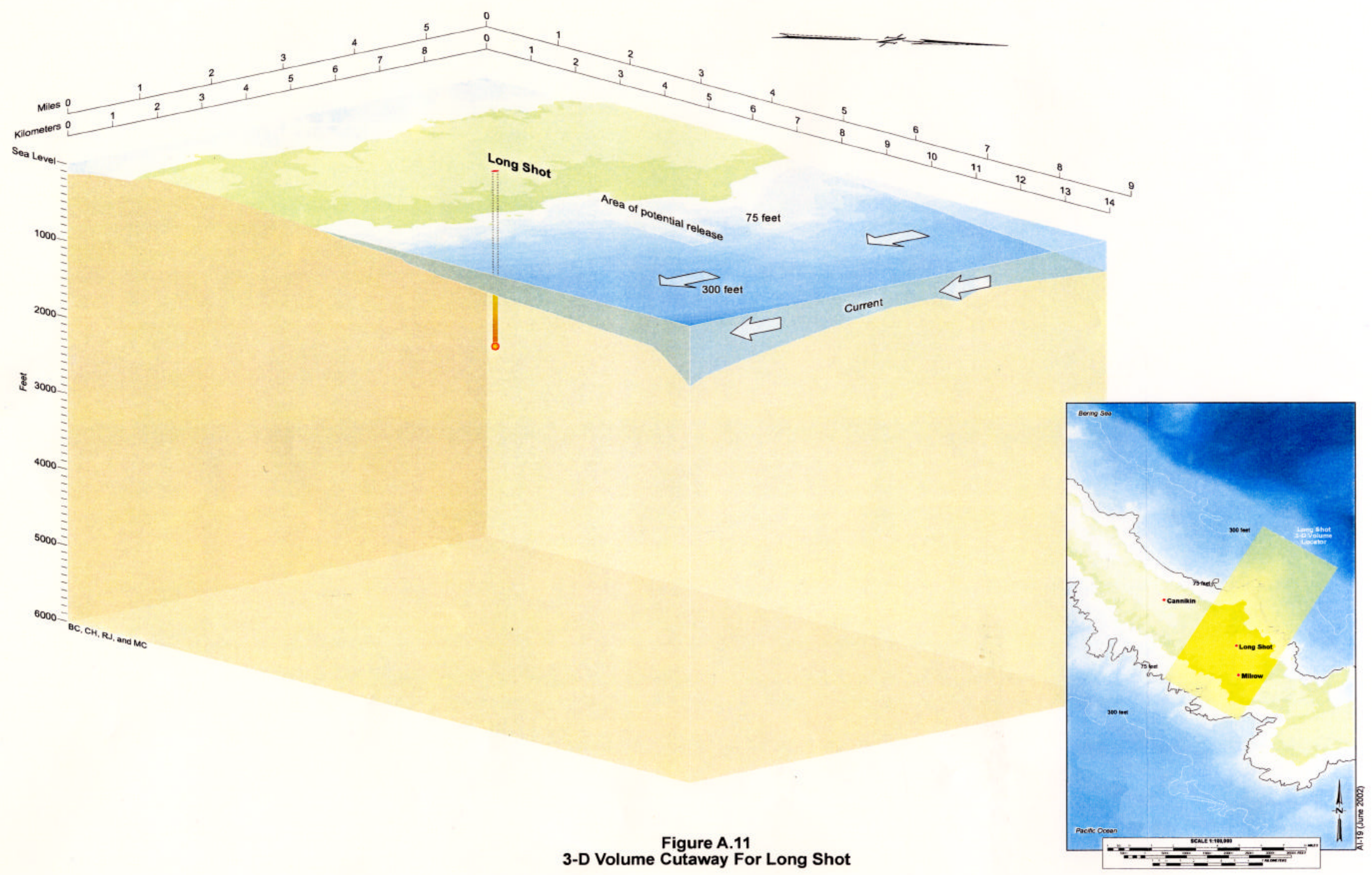




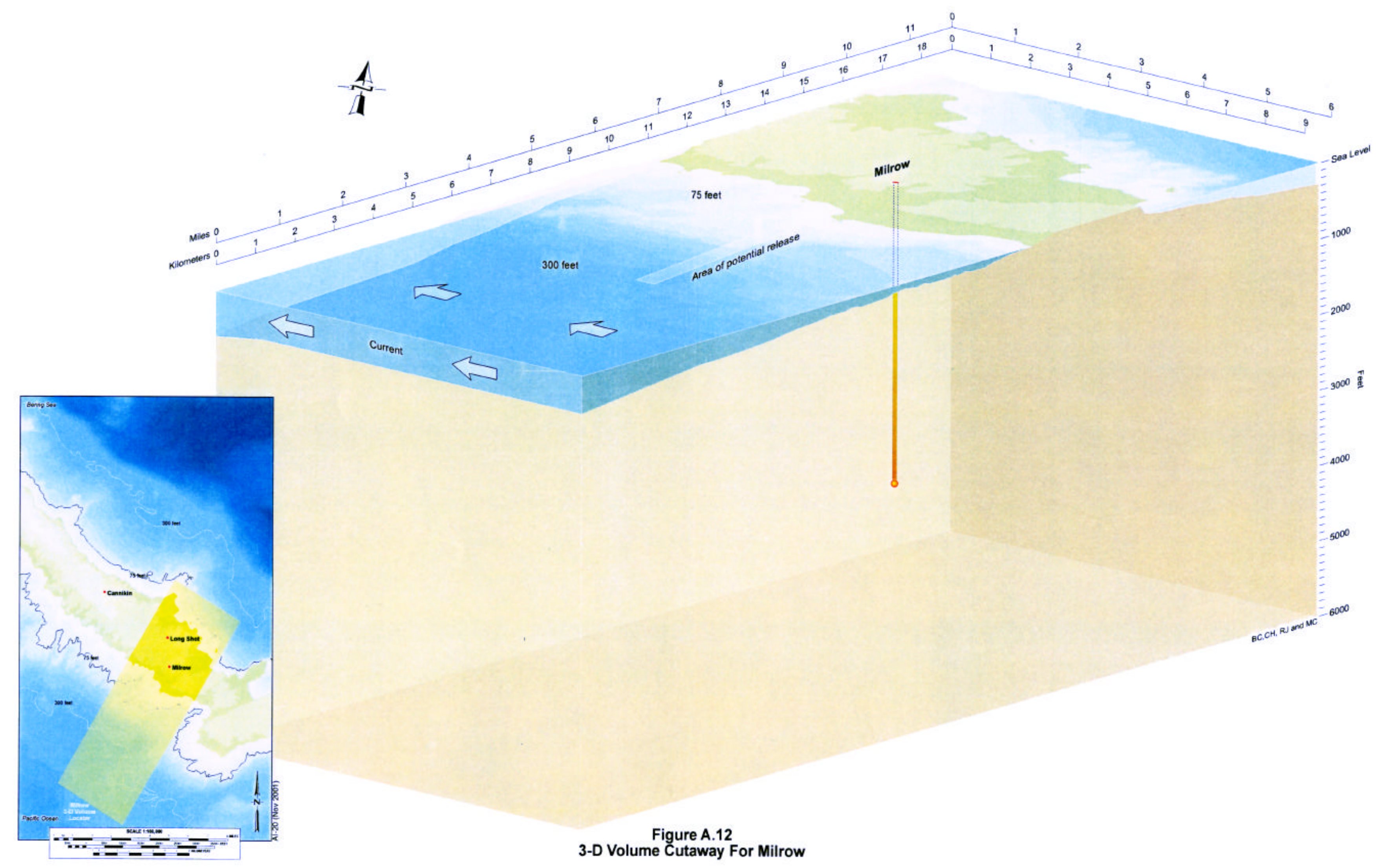




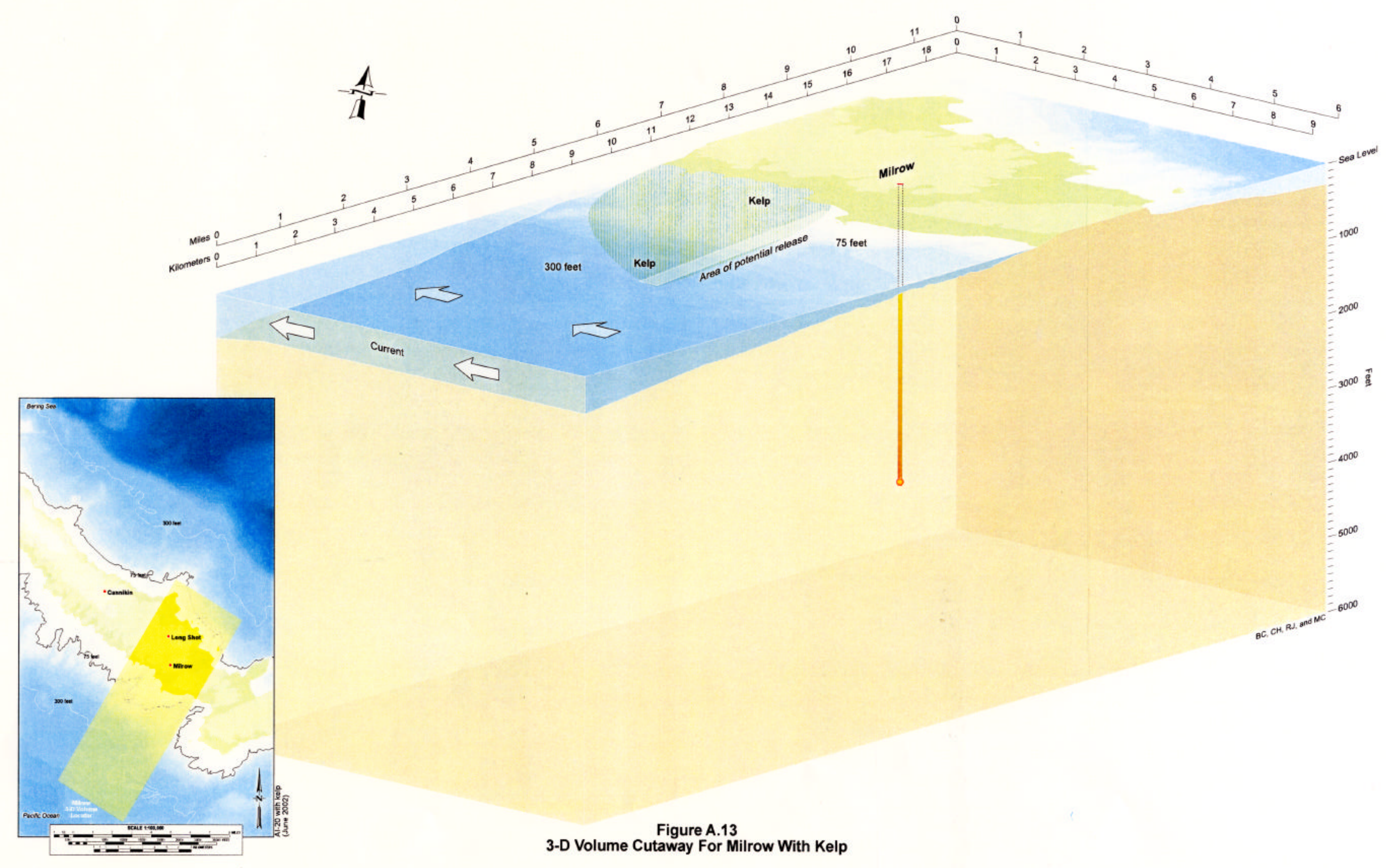




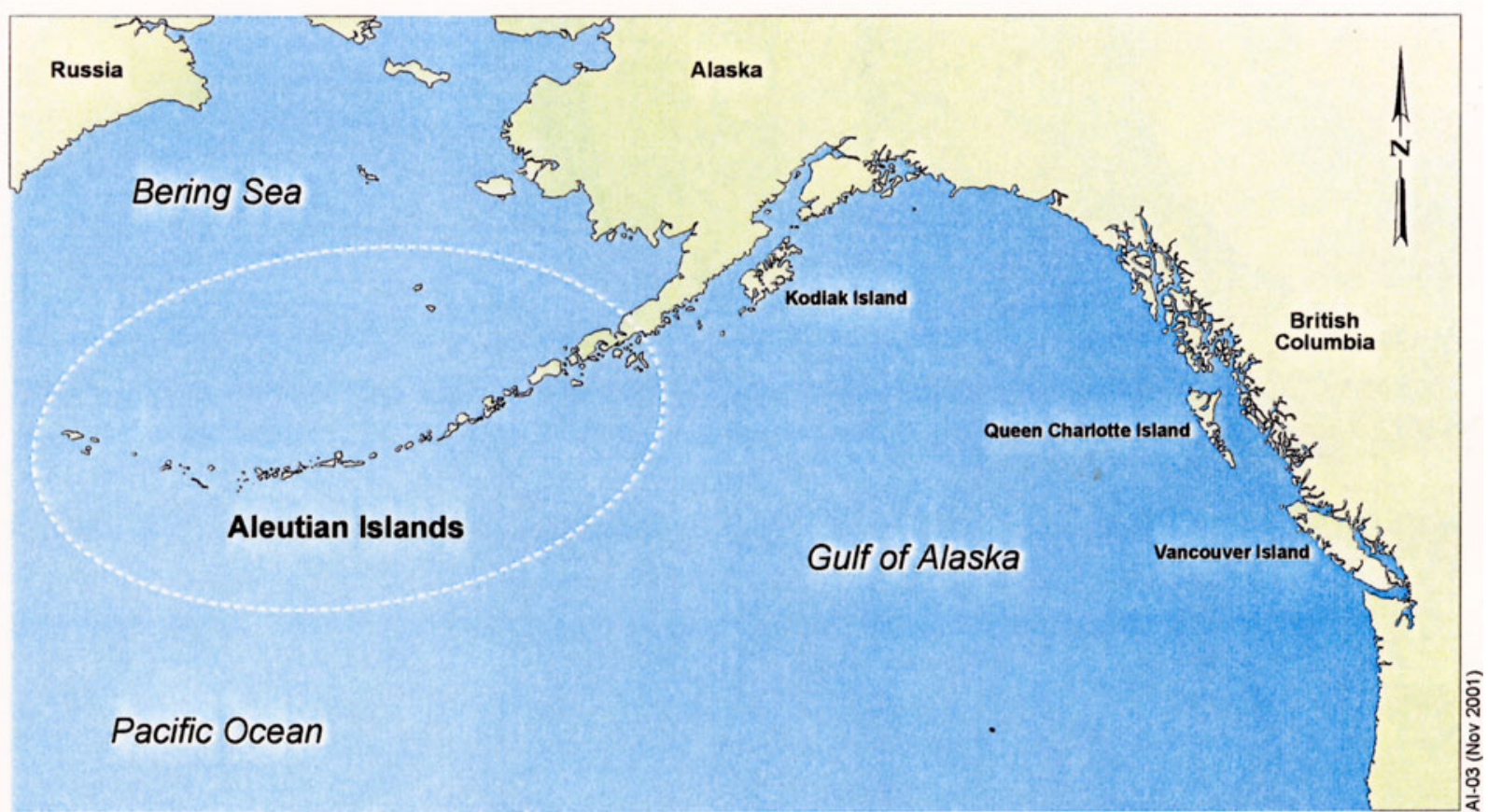

Figure A.14

Geography Around Aleutian Islands and Area of Aleut Culture and Communication as Well as the Large Offshore Exposure Volume (Inside Dashed Line) 


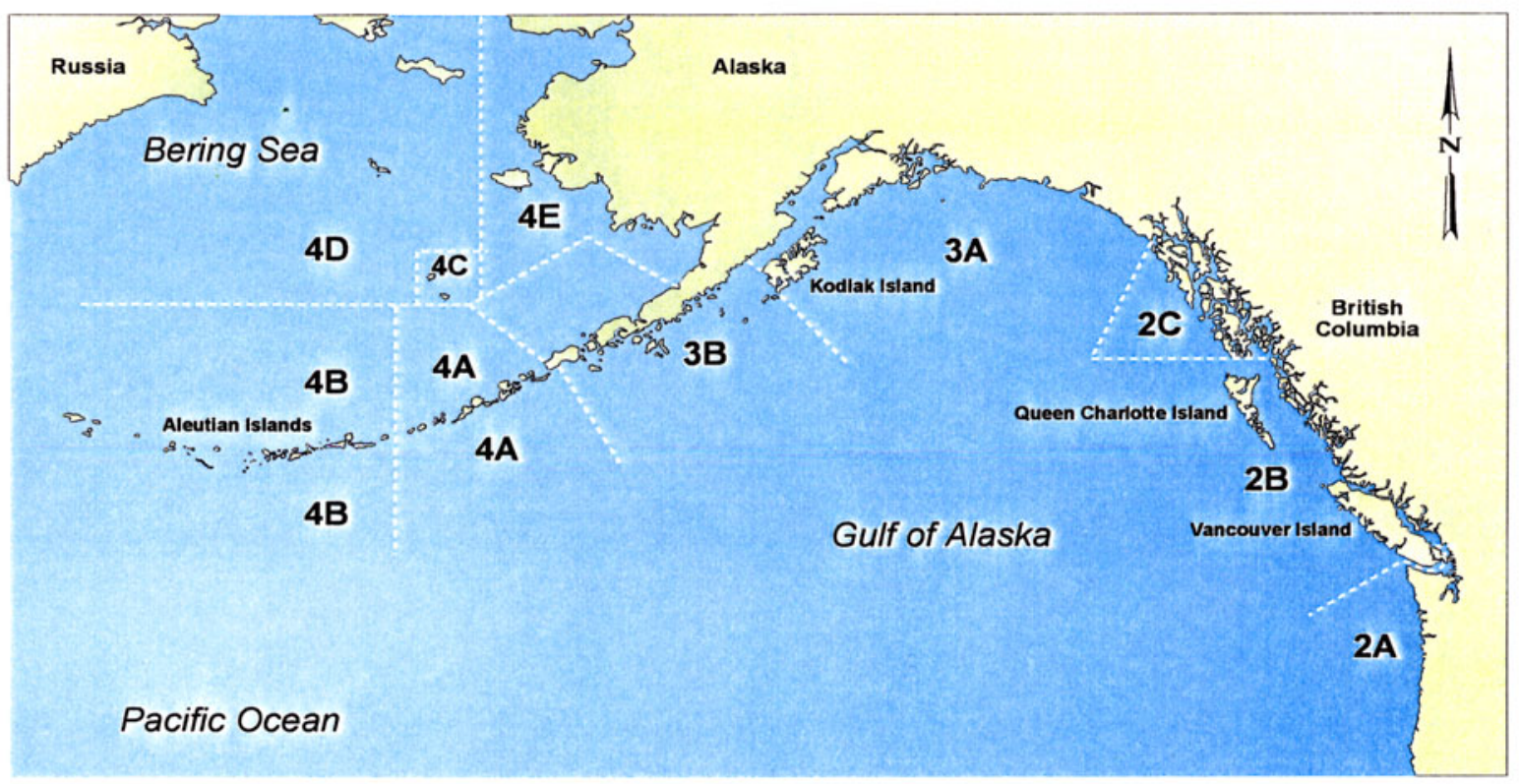

A. Regulatory areas for pacific halibut according to the International Pacific Halibut Commission

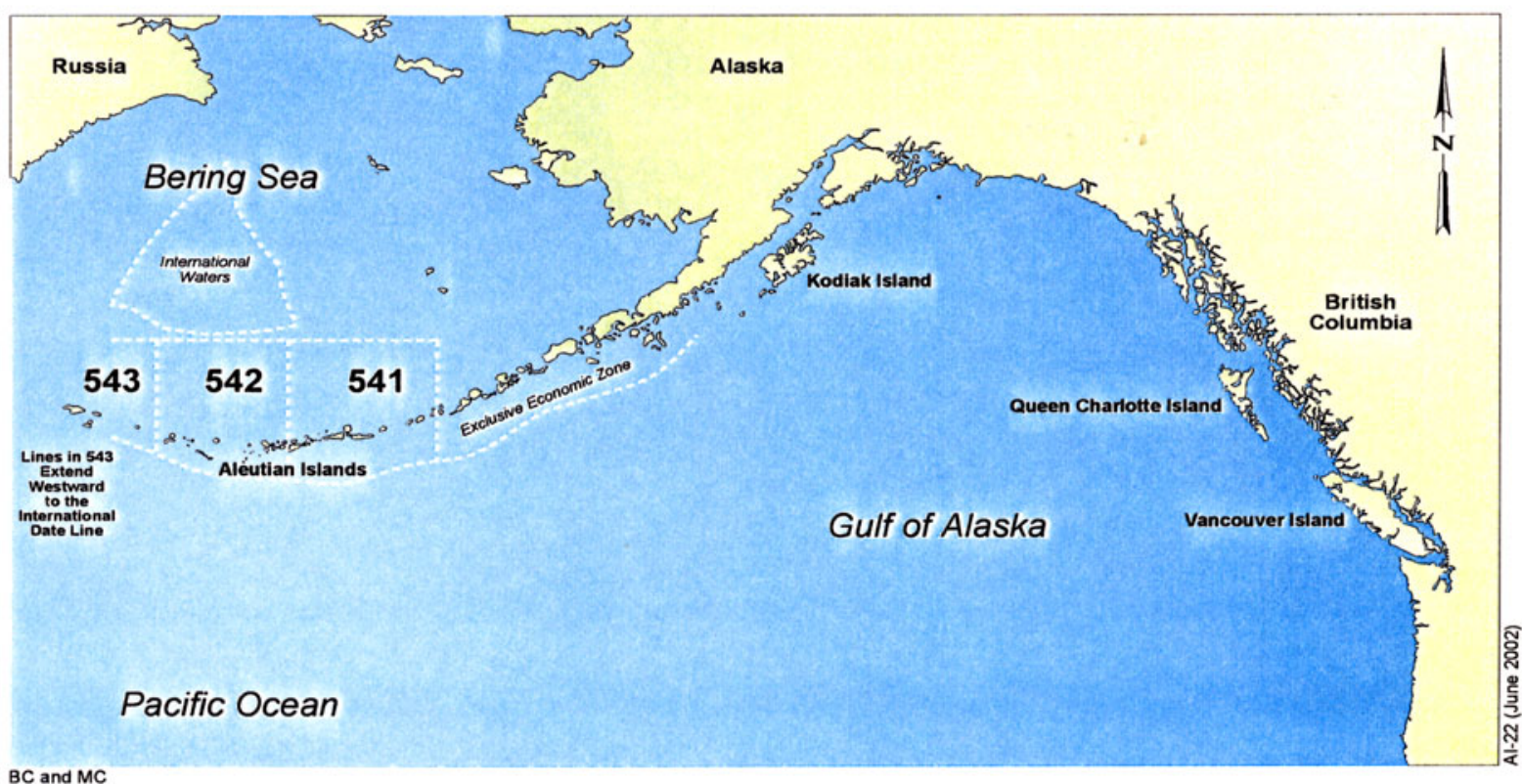

B. Management areas for groundfish fishing according to the National Marine Fisheries Service

Figure A.15

Reporting Areas for Commercial Fishes 


\section{Distribution}

\section{Copies}

Monica Sanchez

Environmental Restoration Division

U.S. Department of Energy

National Nuclear Security Administration

Nevada Operations Office

P.O. Box 98518, M/S 505

Las Vegas, NV 89193

Peter Sanders

Environmental Restoration Division

U.S. Department of Energy

National Nuclear Security Administration

Nevada Operations Office

P.O. Box 98518, M/S 505

Las Vegas, NV 89193

Sabrina Lawrence

Environmental Restoration Division

U.S. Department of Energy

National Nuclear Security Administration

Nevada Operations Office

P.O. Box 98518, M/S 505

Las Vegas, NV 89193

David Rogers

410 Willoughby Avenue

Suite 303

Juneau, AK 99801

Robert Patrick

Aleutian Pribilof Islands Association

201 E. Third Avenue

Anchorage, AK 99501

Jordan Stout

Environmental Contaminants Specialist

U.S. Fish and Wildlife Service

605 West 4th Avenue, Room G-61

Anchorage, AK 99501 


\section{$\underline{\text { Copies }}$}

CRESP c/o Charles Powers, Ph.D.

Executive Director

317 George Street, Suite 202

New Brunswich, NJ 08901-2008

Jenny Chapman

Desert Research Institute

P.O. Box 1940, M/S 433

Las Vegas, NV 89193

Dave Stahl

IT Corporation

P.O. Box 93838

Las Vegas, NV 89193-3838

Mike Murray

Shaw E\&I

2200 Cottontail Lane

Somerset, NJ 08873

Barney Cornaby

SAIC

151 Lafayette Drive

Oak Ridge, TN 37830

IT Corporation

Central Files

P.O. Box 93838

Las Vegas, NV 89193-3838 